
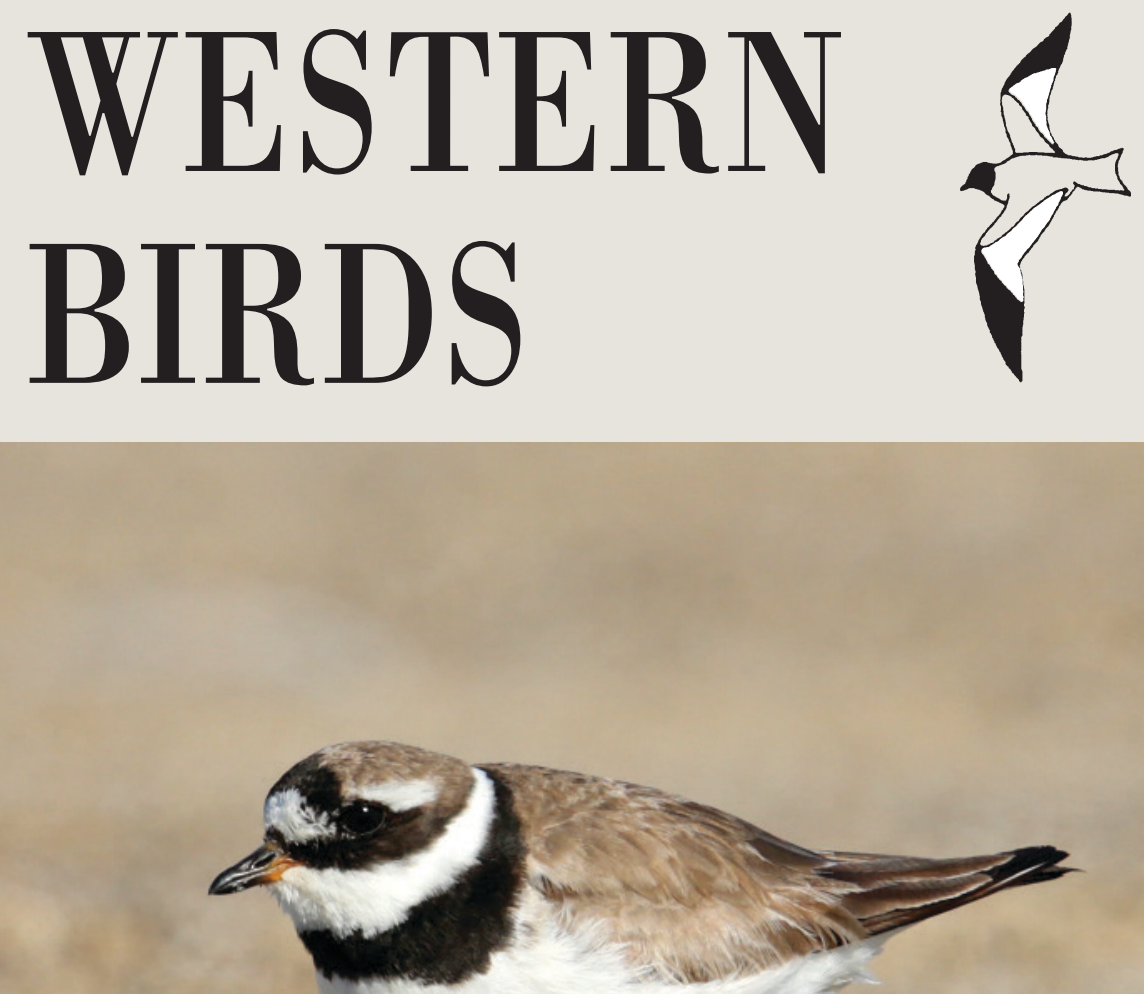


\section{Western Specialty:}

\section{McKay's Bunting}

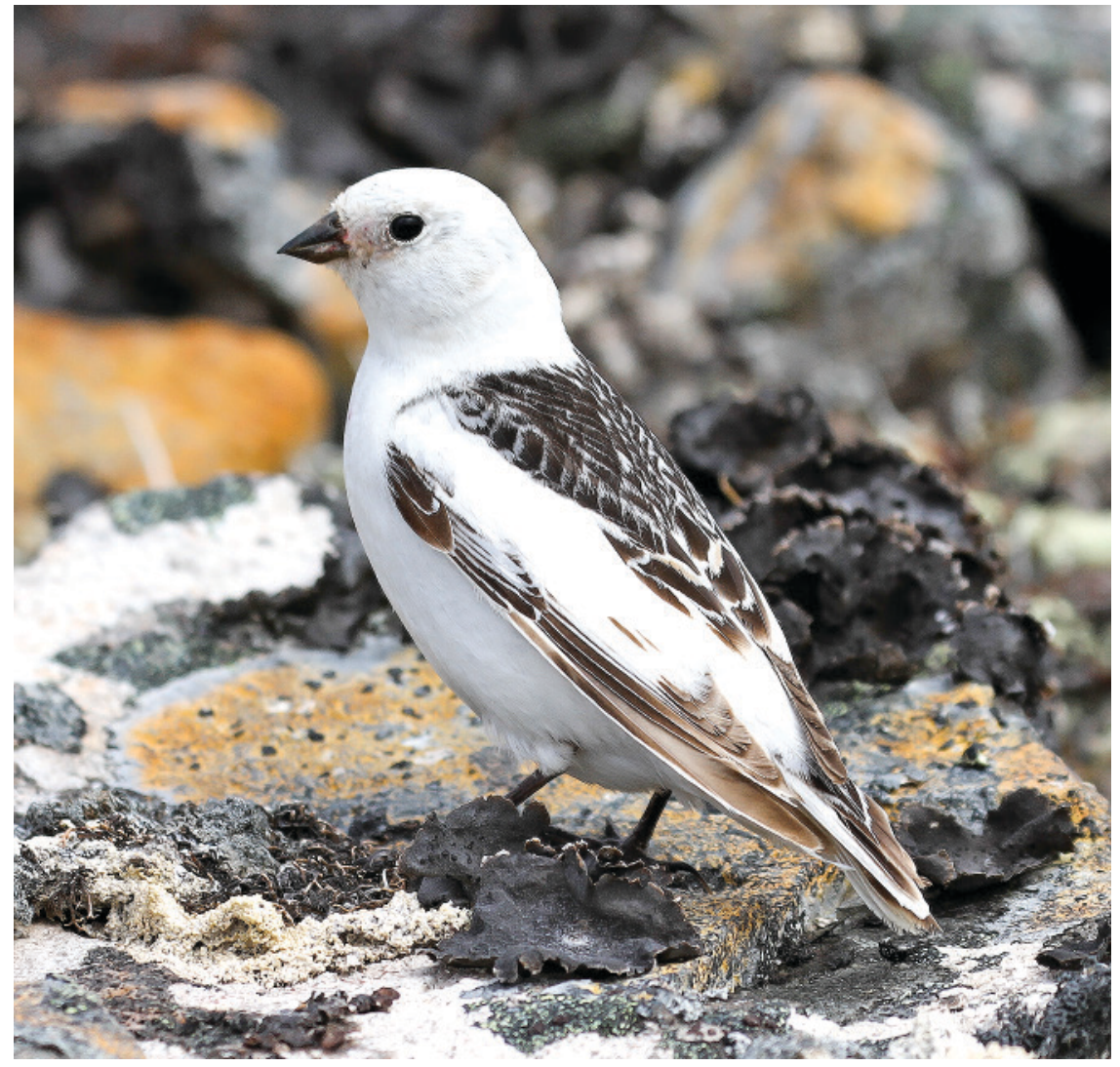

Photo by Rachel Richardson of Anchorage, Alaska:

McKay's Bunting (Plectrophenax hyperboreus), St. Matthew Island, Alaska, 30 June 2018. In this issue of Western Birds, Jack Withrow explores plumage variation in the buntings of the genus Plectrophenax and suggests that McKay's Bunting is a subspecies of Snow Bunting ( $P$. nivalis) instead of a biological species. This female McKay's Bunting shows the broad white edges to the primaries, alula, and tertials, along with primary coverts that are dark for their entire length, that help to distinguish it from a male Snow Bunting at this season. On the basis of the faded primaries it may be a one-year-old bird. Note how a black and white bird can blend in well with the lichens on its preferred nesting substrate of rocky talus. 


\section{Volume 51, Number 3, 2020}

Plumage Variation in Bering Sea Plectrophenax Buntings and the Specific Status of McKay's Bunting Jack J. Withrow

Distribution and Abundance of Colonial Herons and Egrets in California, 2009-2012 W. David Shuford, John P. Kelly, T. Emiko Condeso, Daniel S. Cooper, Kathy C. Molina, and Dennis Jongsomjit

Changes in the Status and Distribution of the Cinereous and

Fulvous Owls in Mexico Nathan Pieplow, Andrew Spencer,

Carlos Sanchez, and Manuel Grosselet.

The $44^{\text {th }}$ Annual Report of the California Bird Records Committee:

2018 Records Thomas A. Benson, Rob Fowler,

Guy McCaskie, and Justyn T. Stahl.

\section{NOTES}

Book Review: An Expedition to Ramsey Canyon: The 1896 Field Journal of Ornithologist Harry S. Swarth Kurt A. Radamaker ........................... 261

Featured Photo: Putative Canyon Towhee $\times$ Spotted Towhee: A New Intergeneric Hybrid David Tønnessen

Front cover photo by (C) Aaron Maizlish of San Francisco, California: Common Ringed Plover, Abbotts Lagoon, Point Reyes National Seashore, Marin County, 15 October 2018, representing the second record for California and the fourth for the Pacific coast of North America south of Alaska of this primarily Old World species.

Back cover "Featured Photo" by (c) David Tønnessen of Colorado Springs, Colorado: Apparent hybrid of a Canyon Towhee (Melozone fusca) $\times$ Spotted Towhee (Pipilo maculatus), the first example of this combination.

Western Birds solicits papers that are both useful to and understandable by amateur field ornithologists and also contribute significantly to scientific literature. The journal welcomes contributions from both professionals and amateurs. Appropriate topics include distribution, migration, status, identification, geographic variation, conservation, behavior, ecology, population dynamics, habitat requirements, the effects of pollution, and techniques for censusing, sound recording, and photographing birds in the field. Papers of general interest will be considered regardless of their geographic origin, but particularly desired are reports of studies done in or bearing on North America west of the 100th meridian, including Alaska and Hawaii, northwestern Mexico, and the northeastern Pacific Ocean.

Send manuscripts to Daniel D. Gibson, P. O. Box 155, Ester, AK 99725; avesalaska@ gmail.com. For matters of style consult the Suggestions to Contributors to Western Birds (at www.westernfieldornithologists.org/docs/journal_guidelines.doc). 


\section{WESTERN BIRDS}

Volume 51, Number 3, 2020

\section{PLUMAGE VARIATION IN BERING SEA PLECTROPHENAX BUNTINGS AND THE SPECIFIC STATUS OF MCKAY'S BUNTING}

JACK J. WITHROW, University of Alaska Museum, Fairbanks, Alaska 99775; jjwithrow@alaska.edu

ABSTRACT: McKay's Bunting (Plectrophenax hyperboreus) is an enigmatic and little studied passerine that breeds only on one of the most isolated groups of islands in North America. Recent field work on those islands, St. Matthew and Hall, and the nearby Pribilof Islands produced specimens of breeding McKay's and Snow Buntings ( $P$. nivalis) demonstrating that plumage variation in both taxa is significant, probably not related to age after the first year, and varies continuously between the extremes within a taxon. The extreme of one closely approaches that of the other. McKay's Buntings are paler overall and levels of black pigmentation of the wings, back, and tail, in conjunction with sex, allow qualitative diagnosability of these taxa by plumage in nearly $100 \%$ of individuals if enough of the bird can be seen. Levels of plumage variation are congruent with recent genomic work suggesting their relationship is extremely close. Current information suggests that McKay's Bunting is not a biological species and should be considered a subspecies of the Snow Bunting.

McKay's Bunting (Plectrophenax hyperboreus) is one of the least studied passerines in North America. It is endemic to the Bering Sea, breeding only on St. Matthew and Hall islands and wintering along the eastern coast of the Bering Sea (see Lyon and Montgomerie 1995). Extralimitally, it has been reported from the Chukchi and Kamchatka peninsulas (summarized by Arkhipov and Lawicki 2016) and coastal British Columbia, Washington, and Oregon (e.g., Campbell et al. 2001, Marshall et al. 2003, Wahl et al. 2005, Nehls 2014, Mlodinow and Bartels 2016). Probably fewer than 250 specimens of McKay's Bunting exist in the world's collections, and rarely has any one ornithologist been able to view more than a handful of specimens together. Consequently, the level of variation within this taxon and nearby populations of the Snow Bunting (P. nivalis) has been underappreciated.

Field work on St. Matthew and Hall islands in early June of 2018 and St. Paul Island in the Pribilof Islands in late May 2018 resulted in the collection of 20 male and 20 female McKay's from St. Matthew and 17 male and 13 female Snow Buntings from St. Paul Island. The surveys were part of the University of Alaska Museum's (UAM) continuing efforts to archive, through specimens and their associated parts, a record of the avifauna of Alaska (see Winker and Withrow 2013, 2017). The most recent estimate of the population of McKay's Bunting is 30,000 individuals (Matsuoka and Johnson 2008), with an annual mortality in the range of $\sim 30-40 \%$ (Lyon and Montgomerie 1995). Before 


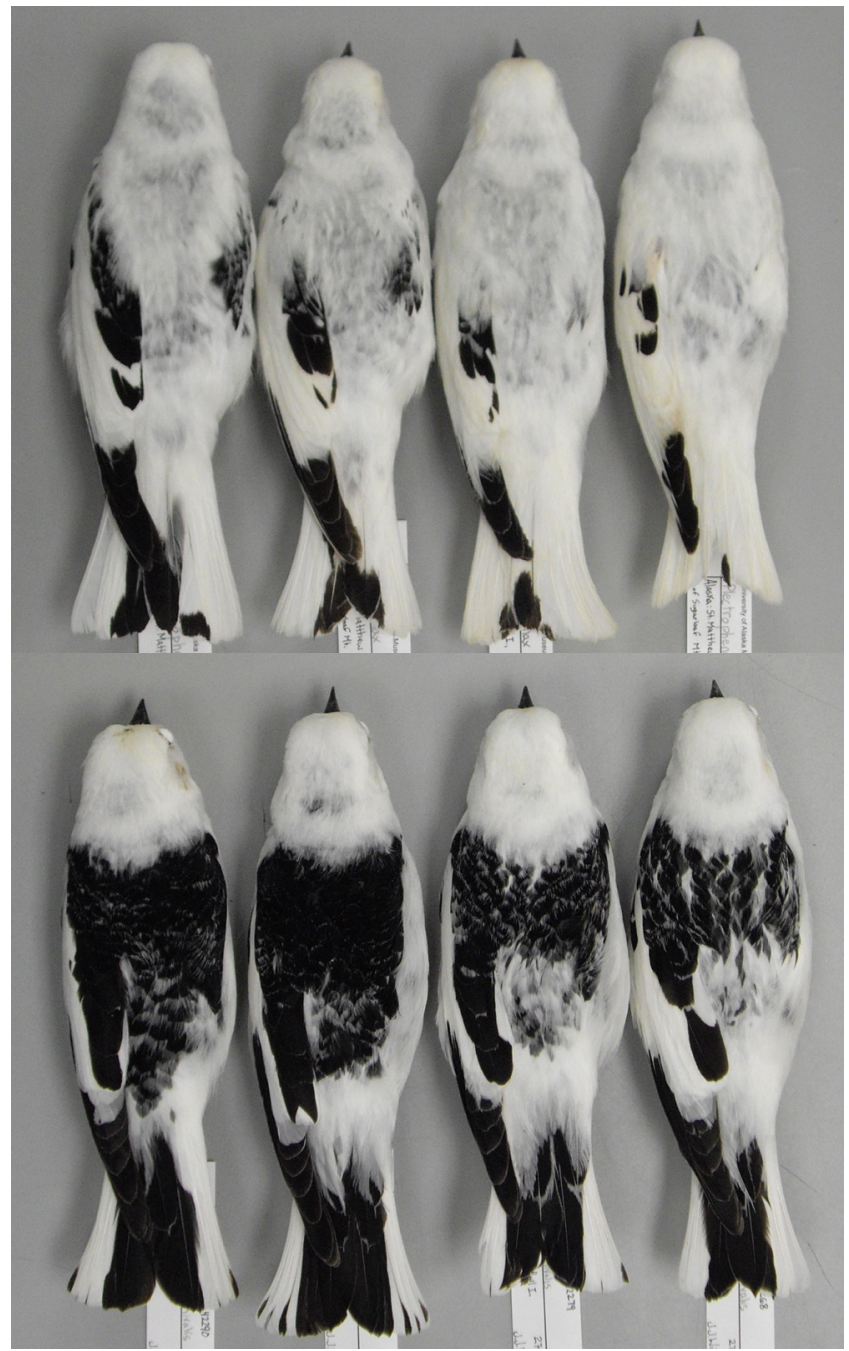

FIgure 1. Examples of male McKay's Buntings from St. Matthew Island (top; left to right, UAM 42263, 42237, 42246, and 42232) and male Snow Buntings from St. Paul Island (bottom; UAM 42290, 42289, 42279, and 42268), collected in early June and late May respectively. The rightmost McKay's (UAM 42232) is at the pale end of the spectrum. The middle two birds are fairly typical, while the leftmost bird shows more black in the scapulars than do most McKay's Buntings on St. Matthew Island. Male Snow Buntings on St. Paul I. vary considerably in darkness, and some could be mistaken for female McKay's without careful examination of the wing (see Figure 4). Very fine black streaks in the mantle of McKay's seem to be more common in fall/ winter (i.e., fresh plumage) and/or first-year birds (see Figure 5 for the extremes), but most of these streaks, if they are present at all, have worn off by summer. 


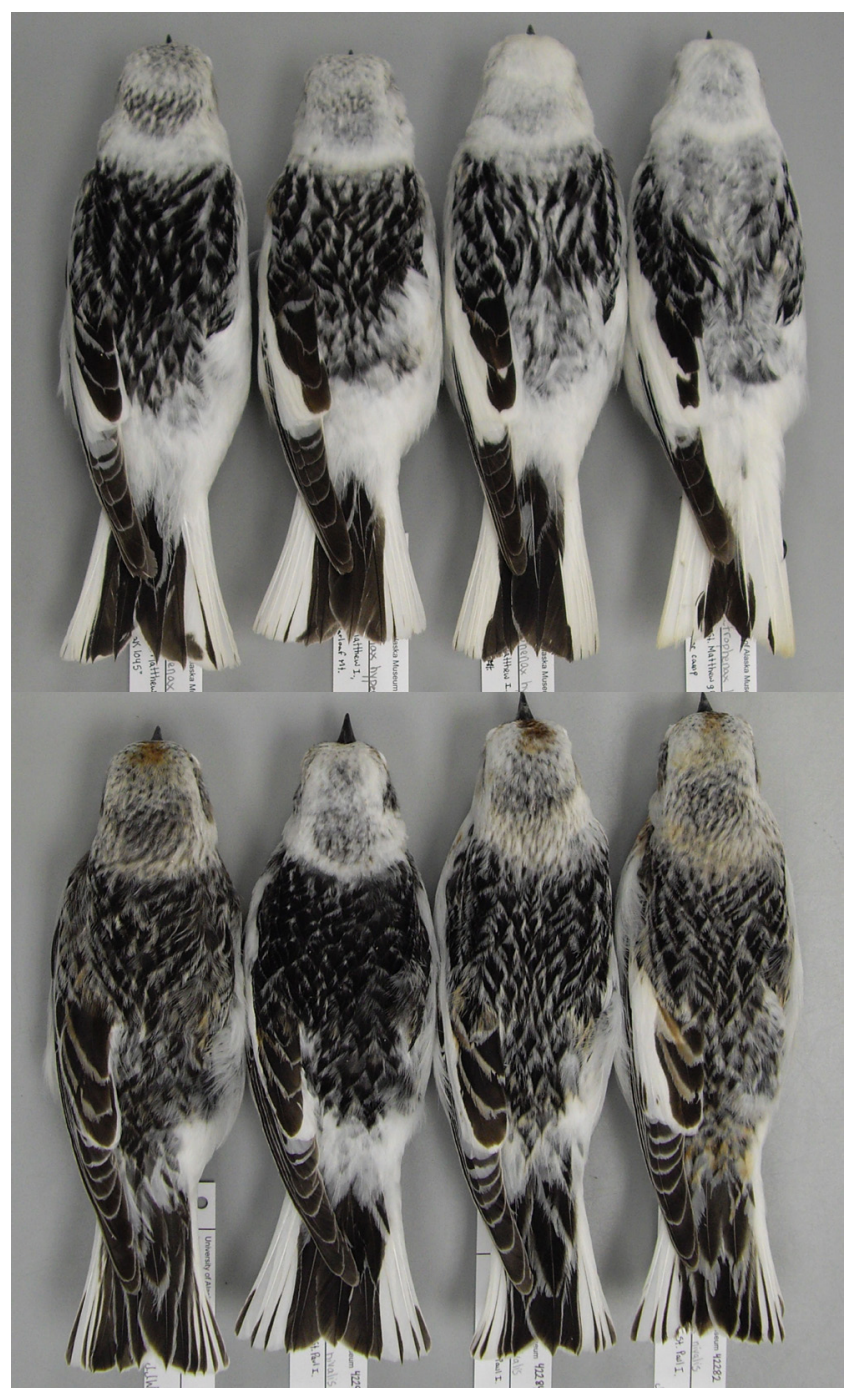

FIgURE 2. Examples of female McKay's Buntings from St. Matthew Island (top; left to right, UAM 42250, 42238, 42234, and 42264) and female Snow Buntings from St. Paul Island (bottom; UAM 42278, 42294, 42284, and 42282) collected in early June and late May, respectively. The middle two McKay's are typical; the rightmost and leftmost birds represent the pale and dark extremes. Note that the palest example of McKay's is one year old, suggesting that individual variation is at least as great as any variation due to age. The darkest summer-plumaged McKay's can be impossible to distinguish from a female Snow Bunting when details of the wing and tail coloration are obscured. Even then, with samples sizes high enough, some examples will likely defy categorization (see text). 


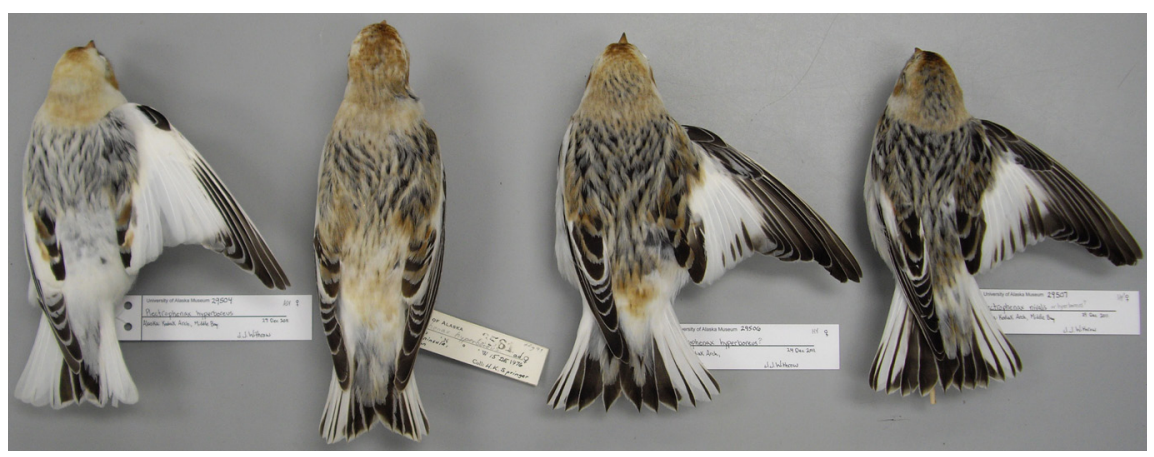

Figure 3. Four female Plectrophenax buntings collected in December; left to right, UAM 29504, 3561, 29506, and 29507. The leftmost bird, over one year old, is a typical pale female McKay's. The bird second from left is a first-year bird collected on the Seward Peninsula on the same date as other McKay's Buntings and is tentatively identified as that species from the pale rump, narrow black markings on the mantle feathers (hard to see in this photo), and a third rectrix that is about $1 / 3$ dark (not visible in photo). This bird has dark markings (again not visible here) on the outer vane of the five outermost secondaries, as does the bird second from right. This specimen, UAM 29506, despite being a first-year bird, is quite similar to UAM 3561 but is probably a Snow Bunting on the basis of its darker rump, third rectrix being mostly dark, and mantle feathers with broader black "V"s (easier to see in hand when feathers can be examined individually). The bird at the far right (first year) is still on the pale end of the Snow Bunting spectrum, mostly through a reduction in the extent of rusty fringing. The palest winter-plumaged female Snow Buntings can look nearly identical to the darkest winter McKay's, and it is likely that not all birds can be safely identified in the field without exceptional views. In a large sample some would likely be perfectly intermediate. Note the provisional identifications on the Snow Bunting labels from when they were prepared that are at odds with concepts I advance here.

2018, no specimens of McKay's Bunting had been collected from St. Matthew Island in early June, let alone a series from which the bounds of "normal" breeding plumage could be easily inferred. The majority of McKay's Bunting specimens from St. Matthew Island have been collected in late summer (July, August) when the plumage of adults is extremely worn, making detailed plumage comparisons difficult. In comparisons of Plectrophenax buntings, it is important that specimens be in similar states of plumage wear because the birds' appearance changes markedly through the year and wear accelerates during the breeding season. Plectrophenax buntings follow a complex basic molt strategy (as defined by Howell et al. 2003), with juveniles undergoing a partial preformative molt in which they replace body feathers and a few wing coverts only (Lyon and Montgomerie 1995). Both the preformative and prebasic molts take place from late July to September, and the breeding plumage is acquired through subsequent wear (Lyon and Montgomerie 1995). The pattern of white and black pigments within a feather that manifests as the breeding plumage of these buntings is much harder to discern in fresh winter-plumaged birds, when the rusty fringes of many feathers obscure underlying patterns.

Specimens collected in 2018 were prepared as round skins with a separate 


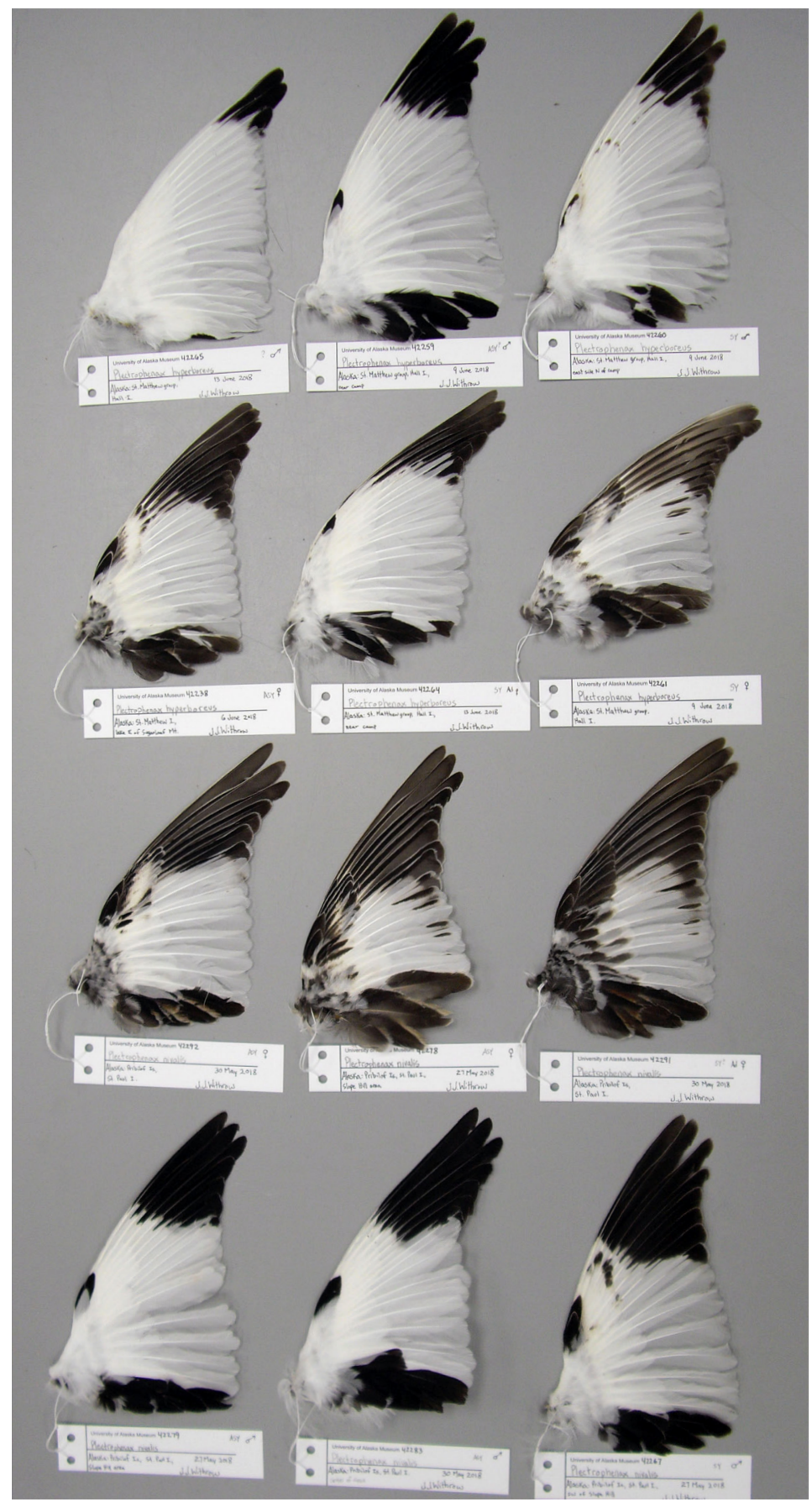


spread wing and associated tissue, stomach, and gut samples. They were sexed by examination of the gonads. All but one of these birds were collected at random, without regard to coloration, the sole exception being a male McKay's Bunting with darker scapulars on Hall Island (Figure 1). This series, part of the largest single museum holding of McKay's Bunting (140+), plus a large series of breeding Snow Buntings from Alaska, provided a solid foundation from which detailed plumage comparisons can be made. In UAM's specimens, the 2018 series in particular, it is obvious that there is significant variation in the extent of black pigmentation in both taxa. Here I provide photographs of what can be subtle identification criteria and provide examples of instances where criteria have broken down or where previous authors have overgeneralized, thus outlining previously underappreciated levels of variation in these birds. I conclude by summarizing what this expanded understanding of the phenotype, along with new genomic data, suggests taxonomically for the genus Plectrophenax.

My comparisons are largely between the series of $P$. hyperboreus and $P$. nivalis townsendi from 2018 (see above). Assessment of other Beringian subspecies of the Snow Bunting is beyond the scope of this paper, although the conclusions about separation of hyperboreus from the rest of nivalis are no doubt transferrable. All specimens from Beringia, if not the Holarctic, need to be reexamined to assess the validity (diagnosability, sensu Patten and Unitt 2002), in relation to nominate nivalis \{type locality Lapland\}, of vlasowae (Portenko, 1937)\{Wrangel Island\}, pallidior (Salomonsen, 1947)\{Amurland\}, and townsendi (Ridgway, 1887) \{Otter Island, Pribilof Islands\}. For example, the distinction between townsendi and nivalis "should be understood ... [as] a conventional arrangement due to the need of drawing a dividing line where there is none in nature" (Swarth 1934:55). Dementev and Gladkov (1970) synonymized vlasowae with townsendi. I am skeptical that the Bering Strait represents a meaningful taxonomic line in the Snow Bunting, e.g., three June skins of nivalis from near Anadyr, Russia, do not appear different from Alaska birds in plumage (University of Washington Burke Museum 82265, 82266, and 82268). See Lehman (2019) for observations of probable continental interchange. It is interesting to note that both vlasowae and townsendi were described as larger island forms. Portenko (1989) clearly restricted vlasowae to Wrangel Island (cf. Dickinson and Christidis 2014), and only after the original description was the name broadened through the principle of priority to represent birds apparently paler than the nominate subspecies occurring in most of Russia (i.e., Salomonsen's pallidior; see Vaurie 1956, Lyon and Montgomerie 1995, cf. Portenko 1989).

FIgURE 4. Spread wings of late May-early June buntings, from top to bottom, three male McKay's Buntings from St. Matthew Island (left to right, UAM 42265, 42259, 42260), three female McKay's Buntings from St. Matthew Island (UAM 42238, 42264, and 42261), three female Snow Buntings from St. Paul Island (UAM 42292, 42278, and 42291), and three male Snow Buntings from St. Paul Island (UAM 42279, 42283, and 42267). The rightmost wings are all from one-year-old birds, the rest are from birds at least two years old, except for the middle female McKay's (UAM 42264), which is a from a very pale one-year-old (see Figure 2 ). In the primary coverts of first-year male Snow Buntings, the dark is restricted to the tips of the coverts, unlike in female McKay's, where the dark (when present) is more uniformly distributed and often extends to the base of the feathers as well (see text). Note also that some male McKay's Buntings in their second cycle have the alula partially dark (see text). 


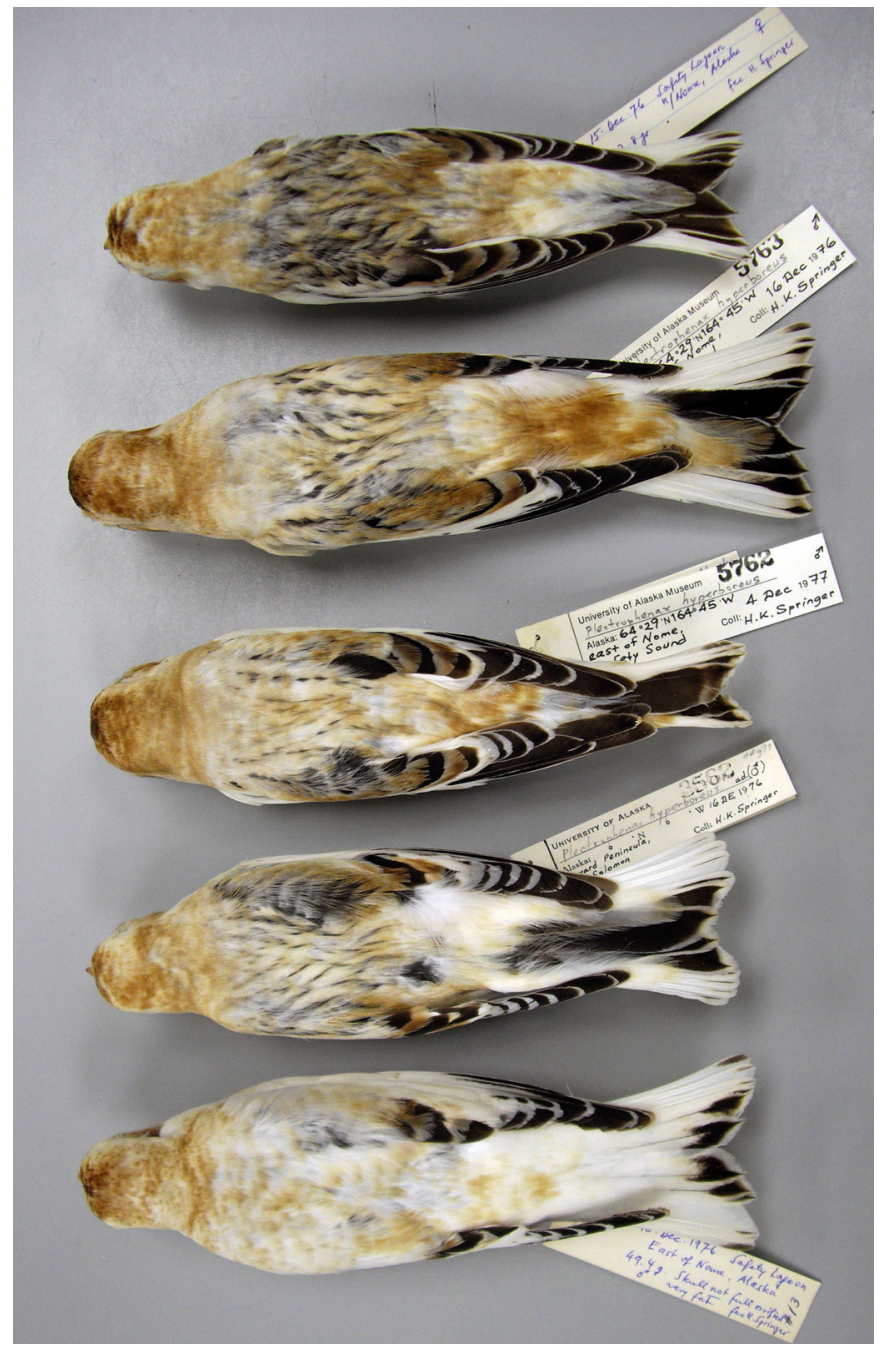

Figure 5. Five McKay's Buntings collected in December from the Seward Peninsula, from top to bottom, UAM 8534, 5763, 5762, 3562, and 8533. The bottom bird is a typical male over one year old without any black in the mantle area. The birds second, third, and fourth from bottom, all males (age greater, less, and less than one year, respectively), show progressively more black in the mantle. The top bird is a first-year female for comparison. Note that the shape of the black markings in the mantle of UAM 5763 differs from their shape in the female, but in this fresh plumage, without close scrutiny, this bird could be mistaken for a female if the paler wing was not discernable. In summer, after the rusty fringing has worn away, UAM 5763 would probably look quite similar to a putative hybrid photographed on St. Matthew by Peter LaTourrette (see figure 10 in Rogers 2005). A minority of male McKay's Buntings show some very fine black streaking in the mantle (usually less even than in these three examples, see text), but the extent to which those with significant streaking may represent intergrades or the extremes of standing variation within McKay's is not known. 


\section{IDENTIFICATION OF McKAY'S BUNTING}

Male McKay's Buntings differ dramatically from male Snow Buntings by having a white as opposed to black mantle and back. The black areas of the wings and tail are also reduced in male McKay's. Females differ less dramatically, but again McKay's shows a general reduction in the level of black pigmentation in the mantle, back, head, wings, and tail. Several detailed descriptions of McKay's Bunting that reference its distinction from the Snow Bunting have been published (e.g., Byers et al. 1995, Pyle 1997, Rogers 2005). The reader is referred to those works for feather-tract-by-feather-tract descriptions and an overview of identification criteria. Here I extend that foundation by focusing on the frequent and significant variation present in individuals and populations. By showcasing exceptions to some generalizations and focusing on cases and aspects that are likely to cause identification confusion, I hope that the reader will be better able to assess confusing or intermediate birds. The few places where my findings diverge from those of previous authors are mentioned below. Overall McKay's Buntings are paler, sex for sex and age for age, than Snow Buntings. Birds were aged by the shape of the outermost rectrix in conjunction with the comparative plumage saturation of pigmented areas (first-year birds are usually a more faded brown color rather than nearly black), particularly when rectrices were worn enough to be of limited use (Swarth 1934, Smith 1992, Svensson 1992, Pyle 2008). Incomplete skull ossification, when noted, was used to age fall birds as being in their first year.

Male McKay's Buntings on St. Matthew vary significantly in the parts of their plumage that are black (Figure 1). In the scapulars, black is usually present only in the posterior portions, but a minority ( 2 of 56$)$ of specimens show significant black throughout the entire scapular region (leftmost bird in Figure 1; UAM 42263). Although this bird was collected to illustrate this trait, this phenotype was noticed several times on St. Matthew. Similarly, some male Snow Buntings from St. Paul have mantles and rumps that are pale enough that, without reference to the level of pigment saturation and wing pattern, they could be mistaken for female McKay's (e.g., rightmost bird in Figure 1). The extent to which the pale extremes of the Snow Bunting and the dark extremes of McKay's are due to intergradation or simply the manifestation of standing variation within a taxon is unclear. For example, Portenko (1989:300) discussed a male Snow Bunting (Zoological Institute of St. Petersburg 73953) taken on the Pribilof Islands on 10 July 1843 as a specimen "transitional" between hyperboreus and nivalis; this specimen resembles UAM 42279 (see Figure 1, third Snow Bunting from left). The continuum between the extremes and more typical looking individuals from each location suggests that, at a minimum, the extremes are not the result of rare instances of hybridization (see below regarding known hybridization and gene flow).

Females buntings of both taxa present the trickiest identification issues (Figures 2 and 3). The darkest female McKay's (leftmost bird in Figure 2) can look nearly identical to the palest female Snow (second from left in Figure 2 ) when details of the wing and tail are not visible. In these two extreme examples, the McKay's (UAM 42250) has only a small amount of dark on rectrix three, no dark in the secondaries, broad white stripes on the outer vane of the primaries, only dark smudging to the bases of the greater primary 
coverts, and only the dark of the outer vane of the outer primaries reaches the primary coverts, attributes that are mostly not visible in this photograph, nor in many field situations. In this Snow Bunting (UAM 42294), rectrix three is nearly all dark, three secondaries have dark spots on the outer vanes, the white stripes on the outer vane of the primaries are present but reduced in comparison with McKay's, the dark at the bases of the greater primary coverts is black as opposed to brownish, and the dark on both vanes of many primaries extends to the primary coverts, again visible only when the wing and tail can be seen well. The palest female McKay's (right bird in Figure 2) could easily be mistaken for a male intergrade if the bird's sex were unknown. Even in hand, some of these pale female McKay's may be nearly indistinguishable from male intergrades by plumage alone. Females in fall and winter plumage, when the feathers have significant rusty fringes that obscure underlying patterns, present the trickiest identifications between these two taxa (see Figure 3).

The wings provide some of the best identification clues in both males and females. They are also less susceptible to the wear-induced plumage changes affecting other areas. The wings of some pale first-year male Snow Buntings can cause confusion with female McKay's, most of which have some dark in the primary coverts. But the dark in the primary coverts of first-year male Snow Buntings tends to be restricted to the tips of the coverts, in contrast to female McKay's, in which the dark (when present) is more uniformly distributed and almost always present at the base of the primary coverts as well (even if absent from the middle part of the primary coverts; Figure 4). Only one of the $20 \mathrm{fe}-$ male McKay's collected in 2018 (UAM 42241, not shown) shows a pattern like a young male Snow Bunting, and the dark tips to the primary coverts of this bird are reduced to mere specks, inviting confusion with the wings of first-year male McKay's. Female McKay's with all white primary coverts can usually be distinguished from male Snow Buntings by the distribution of black in the primaries themselves. The dark in the primaries of female McKay's often reaches the primary coverts (cf. Byers et al. 1995), but when it does, it tends to be only the dark on the outer vane of the primary. In McKay's, the dark of the inner vane fades away closer to the tip of the feather, on average, creating a striped pattern on a spread wing unlike the more abrupt and uniform ending of this dark area on a male Snow Bunting (Figure 4). This difference is not always observable on a folded wing. Additionally, the white outer fringe of the outer vane on female McKay's tends to be more pronounced than in the Snow Bunting, although Snow Buntings can have some minimal fringing too. On female McKay's this fringe serves to accentuate the striped effect on a spread wing. Many (11 of 29) male McKay's older than one year have a partially dark alula (cf. Swarth 1934, Pyle 1997), and this limited black is nearly always restricted to the largest alula feather (UAM 42237, Figure 1, second from left, with dark streaks on two feathers, is an exception). By contrast, in male Snow Buntings the black, in addition to being more extensive, is almost always present in significant amounts on the two longest alula feathers (see UAM 42279 in Figure 4 for an exception). First-year male McKay's usually (15 of 19) have a limited amount of black on the second alula feather (Swarth 1934), but which feathers have dark is nearly impossible to discern unless the bird is in hand. Nearly all female Snow Buntings have the black patch of the primaries extending onto the outer secondaries, but sometimes just to the outer vane of the outermost ones (Figure 
4). A minority (8 of 32) of breeding female McKay's can also have black on the outermost secondaries (usually no more than three, exceptionally five, see Figure 3) and it is always restricted to the outer vane. Sealy (1969) interpreted this variability among McKay's as evidence of interbreeding with the Snow Bunting, but the frequency of this trait is relatively high, and may be higher in fall before the usually minimal patches on the outer vane have worn much.

Within an individual, the formative plumage may be somewhat darker than in subsequent cycles (e.g., dark on primary coverts and outer tail feathers), but there is no evidence that individuals become appreciably paler with successive molts after their second basic plumage, as has been suggested (Byers et al. 1995). The variation seen in a population is thus probably the result of individual variation and not a mix of age classes beyond the second year (and see banding anecdote in Rogers 2005). Swarth (1934:56) observed that other than in the primary coverts and alula "there is overlapping and intergrading of every degree between immatures and adults" (and see above regarding the alula in a sample much larger than Swarth's). Portenko (1989), Smith (1992), and Rogers (2005) all came to similar conclusions about paleness in relation to age, and the considerable variation in first-cycle birds at UAM easily encompasses all variation seen in older birds.

\section{SPECIFIC STATUS OF PLECTROPHENAX HYPERBOREUS}

The biological species concept is the dominant species concept in birds (e.g., AOU 1998, Dickinson and Remsen 2013). Assessment and delimitation of isolated (allopatric) populations under the biological species concept is difficult, and here I operate under the expectation that these two taxa are similar enough that they would likely interbreed were they to occur in sympatry (see Toews 2015). I draw from various lines of evidence to infer that reproductive isolation has not yet arisen, despite phenotypic diagnosability. Thus they are not biological species in the sense of Mayr (1996) and Johnson et al. (1999), as informed by current issues thought to be important in avian speciation and its delimitation. On the basis of plumage McKay's Bunting would qualify as a phylogenetic species (i.e., it is diagnosable). But no genetic marker yet studied identifies the Snow and McKay's Buntings as reciprocally monophyletic (Klicka et al. 2003, Maley and Winker 2010, Winker et al. 2018), although nuclear markers allow for a diagnosis based on allele frequencies (Maley and Winker 2010, Winker et al. 2018). Treated as a subspecies, McKay's Bunting also presumably meets the operational definitions of an evolutionarily significant unit, a distinct population segment, and/or a management unit (see Winker et al. 2007 and citations therein).

McKay's Bunting has been treated by the American Ornithologists' Union (now American Ornithological Society) as a species since the very first edition of the AOU's checklist (1886) appeared a mere two years after Robert Ridgway's description (1884). By contrast, most investigators who have since made an explicit study of plumage variation in Plectrophenax as a whole have concluded that hyperboreus is merely a subspecies of nivalis (Salomonsen 1931, Hellmayr 1938, Vaurie 1959, Portenko 1989). Many other authorities treated it as a subspecies as well (Mayr and Short 1970, Paynter 1970, Cramp and Perrins 1994), influenced by evidence of extralimital pairings of male McKay's with reported female Snow Buntings at St. Lawrence Island (Sealy 
1969). Its stable taxonomic status within the AOU checklist belies a more skeptical undercurrent, e.g., "may be conspecific" (AOU 1998:630), "recognized plumage differences are no more pronounced than among many passerine subspecies" (Maley and Winker 2007:909), although both ultimately treated them as separate species.

Ridgway himself was equivocal regarding the specific status of hyperboreus. At the time he described hyperboreus (Ridgway 1884), trinomials were given only to birds known "to intergrade in physical characters" (AOU 1886:30). As Ridgway himself put it, "every local or geographical variation of size, form, or color, no matter how slight, if reasonably constant, is just so much evidence affecting the question of the derivation of species, and no excuse for the exclusion of such evidence can be allowed" (in Stejneger 1884:79). Because McKay's Bunting is nearly 100\% diagnosable (i.e., "constant"; in 1884 Ridgway was working from seven specimens), by the concept of species at the time (long before the development of the biological species concept), it was acceptable to treat it as such. However, Ridgway's own doubts about the status of this taxon are evident from the ambiguous title of his description ("Description of a new Snow Bunting from Alaska"), the fact that he begins it with "sUBSP. CH." (i.e., subspecies characters), and the designation "Plectrophanes nivalis hyperboreus Ridgw." written in his own hand on each of the original labels of the syntypes at the U. S. National Museum (C. Milensky in litt. 2019).

Snow and McKay's buntings do not display any known prezygotic reproductive isolating mechanisms in behavior or ecology. Their songs are usually described as similar, but Plectrophenax song is relatively complex and at least in Snow Buntings subject to regional, individual, and even annual variation (Espmark 1994, Baldo et al. 2014). Even if a rigorous quantification of song showed a difference between the two, it would remain to be demonstrated that any differences affected mate choice and levels of introgression. Differences in timing of migration and habitat saturation (Winker et al. 2002, Matsuoka and Johnson 2008) may be acting as isolating mechanisms, but these are likely too porous or too recent to allow or to have resulted in speciation (see below regarding gene flow levels). Under the biological species concept, geographic isolation alone, even if reinforced by differences in phenomena such as migration timing and habitat saturation, is not considered a reproductive isolating mechanism (Mayr 1996). However, this dynamic, a form of heteropatry, can be an important driver of divergence in birds (Winker 2010) and is probably operating to some extent here: Snow Buntings appear to be uncommon during spring migration at St. Matthew Island (Winker et al. 2002), but they are scarce there at other times (see Robinson et al. 2020). For example, in June of 2003, during transect counts of 2400 McKay's Buntings, zero Snow Buntings were identified and only five (all males) were seen off transects, the latest on 5 June (Matsuoka and Johnson 2008), suggesting that the two forms are effectively allopatric during the breeding season. A gap in breeding distribution of at least $264 \mathrm{~km}$, reinforced by a process of heteropatry, may be why intergrades are not rampant, but see above regarding significant variation that could be interpreted as evidence of intergradation, and below on gene flow. Field research into mate preference and heterospecific interactions would be instructive, but any differences are likely to be minor given the overall similarities. Furthermore, in many cases levels of assortative mating must be 
very high for that factor to be an effective isolator (Irwin 2020). "It is unlikely that effective postzygotic reproductive isolating mechanisms have evolved, and fertile hybrids would be expected" (Maley and Winker 2010:10).

The differences in juvenal plumage have been adduced as evidence for species rank (Maley and Winker 2007), but, like the adult plumage, the juvenal plumage is variable, and some individuals are borderline cases (see Figure 2a in Maley and Winker 2007; visual examination of 50+ juvenal-plumaged specimens of Plectrophenax at UAM). Furthermore, recognition that the Snow Buntings and longspurs constitute their own family Calcariidae (Chesser et al. 2010) frees them from an expectation that they have a distinctive juvenal plumage as is typical in the family Emberizidae (sensu lato) in which they were previously classified. Some evidence suggests those plumages are evolutionarily conserved (see citations in Maley and Winker 2007), a situation that informed the conclusions of that study (ibid.). Graber (1955), in his review of the juvenal plumages of the Emberizidae (as previously constituted), had already pointed out that Plectrophenax does not follow those patterns. In the closely related longspurs (Calcarius, Rhynchophanes), the juvenal plumage is reminiscent of the adult female plumage, as in Plectrophenax, so there may be no reason to assume any differences reflect a deep evolutionary divide, particularly when they are subtle (a matter of shading). Whether morphological integration of adult-like characters, selection, drift, phenotypic plasticity, and/or some other mechanisms are responsible for this difference remains to be discovered.

Initial genetic work on McKay's Bunting (Maley and Winker 2010) detected only small differences from the Snow Bunting. Their estimates of gene flow in mitochondrial DNA were not seen as robust enough to be a base for taxonomic conclusions. More recent genomic work on the buntings (Winker et al. 2018) found no fixed differences between the species across 3431 ultraconserved loci, few loci at which the frequency of alleles differed widely, and an overall $F_{\mathrm{ST}}=0.034$, genomic attributes that cast doubt on the reproductive isolation of McKay's Bunting. Most importantly, this work suggests that levels of long-term gene flow between McKay's and Snow buntings, far more robust estimates than the mtDNA-based methods of Maley and Winker (2010), are higher than expected between species (3-5 individuals per generation in each direction). The interplay among selection, drift, and the levels of gene flow necessary to counter divergence in practice are only beginning to be understood, but theory suggests that under neutral conditions gene flow from one individual or more per generation will prevent divergence from progressing (see Mills and Allendorf 1995, Lenormand 2002, Wang 2004, Postma and van Noordwijk 2005, Polechová and Barton 2015, Leaché et al. 2018, Winker 2018). Under selection, this number can rise, but how high is unclear; it is probably very low in relation to effective population size (e.g., Mallet 2008). Gene-flow estimates are perhaps the best proxy we have for inferring the aggregate effects of isolating mechanisms and thus potentially informative regarding species limits. Although gene-flow estimates are sensitive to violations of the model under which they are inferred (e.g., selective neutrality), they are likely to be informative in many cases, and in this case no isolating mechanisms producing selective pressures against hybrids are known.

Snow Buntings have never been documented breeding on St. Matthew Island (Winker et al. 2002, Robinson et al. 2020). The limited evidence for 
extralimital breeding by McKay's has rarely been accompanied by detailed documentation of the phenotypes involved, but phenotypic McKay's, usually males, are seen in very small numbers, less than annually, during the summer in the Pribilof Islands and on St. Lawrence Island (see Kenyon and Phillips 1965, Sealy 1967, 1969, Kessel and Gibson 1978, Lehman 2019, S. Schuette in litt. 2019, UAM unpublished data). The male McKay's Buntings collected by Spencer Sealy on St. Lawrence Island (University of British Columbia 13274, 13327, and 13328) are typical McKay's. As a parallel to this situation, in the North Atlantic P. n. insulae from Iceland occurs in winter on the British Isles and mainland Europe (see Banks et al. 1991, Winters 2013) but occasionally breeds on Jan Mayen, the Faroe and Shetland islands, and northern Scotland, where some birds are intermediate with nominate nivalis (Nethersole-Thompson 1966, Smith 1996, Shirihai and Svensson 2018). Subspecies insulae, distinguished from nominate nivalis by being darker in nearly all the same respects that hyperboreus is paler, offers an instructive analog to which McKay's Bunting may be compared.

Current evidence suggests that McKay's Bunting has not achieved reproductive isolation from the Snow Bunting and is maintaining its distinctiveness through an effectively allopatric breeding range, possibly reinforced by differences in migration timing, philopatry, and high density of the breeding population. Barring the discovery of some very effective reproductive isolating mechanism, it seems likely that the small differences between these two taxa would break down further if they were to come into significant contact while breeding. In many ways, the recognition of considerable phenotypic (plumage) variation in Plectrophenax, requiring the congruence of several attributes to yield an identification in some cases, mirrors the necessity of a genomic diagnosis based on allele frequencies. In this sense, the phenotypic evidence is congruent with the genetic evidence, and McKay's Bunting should be considered a subspecies of the Snow Bunting. In this case, diagnosability does not a biological species make.

\section{ACKNOWLEDGMENTS}

Ildiko Szabo provided photographs of buntings in the University of British Columbia's Beaty Biodiversity Museum. Vladimir Loskot provided photographs and information on buntings in the Zoological Institute, St. Petersburg, Russia. Rob Faucett kindly provided access to the University of Washington Burke Museum collection. The Alaska Maritime National Wildlife Refuge provided permits and access to St. Matthew Island aboard the R/V Tighla $\hat{x}$. Lauren Divine of the Aleut Community of St. Paul Island kindly provided permission to work on St. Paul. Dan Gibson, Kevin Winker, Jon Dunn, James Maley, and Dan Ruthrauff provided helpful comments on the manuscript.

\section{LITERATURE CITED}

American Ornithologists' Union (AOU). 1886. The Code of Nomenclature and Checklist of North American Birds. Am. Ornithol. Union, New York.

AOU. 1998. Check-list of North American Birds, $7^{\text {th }}$ ed. Am. Ornithol. Union, Washington, DC.

Arkhipov, V. Yu., and Lawicki, L. 2016. Nearctic passerines in Russia. Dutch Birding 38:201-214. 
Baldo, S., Mennill, D. J., Guindre-Parker, S., Gilchrist, H. G., and Love, O. P. 2014. Snow Buntings sing individually distinctive songs and show inter-annual variation in song structure. Wilson J. Ornithol. 126:333-338; doi.org/10.1676/13-157.1.

Banks, K. W., Clark, H., Mackay, I. R. K., Mackay, S. G., and Sellers, R. M. 1991. Origins, population structure and movements of Snow Buntings Plectrophenax nivalis wintering in Highland Region, Scotland. Bird Study 38:10-19; doi. org/10.1080/00063659109477062.

Byers, C., Curson, J., and Olsson, U. 1995. Sparrows and Buntings: A Guide to the Sparrows and Buntings of North America and the World. Houghton Mifflin, Boston.

Campbell, R. W., Dawe, N. K., McTaggart-Cowan, I., Cooper, J. M., Kaiser, G. W., Stewart, A. C., and McNall, M. C. E. 2001. The Birds of British Columbia, vol. 4. Royal Br. Columbia Mus., Victoria.

Chesser, R. T., Banks, R. C., Barker, F. K., Cicero, C., Dunn, J. L., Kratter, A. W., Lovette, I. J., Rassmussen, P. C., Remsen, J. V. Jr., Rising, J. D., Stotz, D. F., and Winker, K. 2010. Fifty-first supplement to the American Ornithologists' Union Check-list of North American Birds. Auk 127:726-744; doi.org/10.1525/auk.2010.127.3.726.

Cramp, S., and Perrins, C. M. (eds.). 1994. Birds of the Western Palearctic, vol. IX. Oxford Univ. Press, Oxford, England.

Dement'ev, G. P., and Gladkov, N. A. 1970. Birds of the Soviet Union, vol. V. Israel Program for Scientific Translations, Jerusalem.

Dickinson, E. C., and Christidis, L. 2014. The Howard and Moore Complete Checklist of the Birds of the World, $4^{\text {th }}$ ed., vol. 2. Aves Press, Eastbourne, England.

Dickinson, E. C., and Remsen, J. V. Jr. 2013. The Howard and Moore Complete Checklist of the Birds of the World, $4^{\text {th }}$ ed., vol. 1. Aves Press, Eastbourne, England.

Espmark, Y. 1994. Individual and local variations in the song of the Snow Bunting (Plectrophenax nivalis) on Spitsbergen. Bioacoustics 6:117-133; doi.org/10.108 0/09524622.1995.9753279.

Graber, R. R. 1955. Taxonomic and adaptive features of the juvenal plumage in North American sparrows. Ph. D. dissertation, Univ. Okla., Norman.

Hellmayr, C. E. 1938. Catalogue of birds of the Americas. Zool. Ser. Field Mus. 13, part XI.

Howell, S. N. G., Corben, C., Pyle, P., and Roger, D. I. 2003. The first basic problem: A review of molt and plumage homologies. Condor 105:635-653; doi.org/10.1093/ condor/105.4.635.

Irwin, D. E. 2020. Assortative mating in hybrid zones is remarkably ineffective in promoting speciation. Am. Nat. 195, in press; doi.org/10.1086/708529.

Johnson, N. K., Remsen, J. V. Jr., and Cicero, C. 1999. Resolution of the debate over species concepts in ornithology: A new comprehensive biologic species concept, in Proc. 22nd Int. Ornithol. Congr., Durban (N. J. Adams and R. H. Slotow, eds.), pp. 1470-1482. BirdLife South Africa, Johannesburg.

Kenyon, K. W., and Phillips, R. E. 1965. Birds from the Pribilof Islands and vicinity. Auk 82:624-635; doi.org/10.2307/4083224.

Kessel, B., and Gibson, D. D. 1978. Status and distribution of Alaska birds. Studies Avian Biol. 1.

Klicka, J. T., Zink, R. M., and Winker, K. 2003. Longspurs and snow buntings: Phylogeny and biogeography of a high-latitude clade (Calcarius). Molec. Phylogen. Evol. 26:165-175; doi.org/10.1016/S1055-7903(02)00360-3.

Leaché, A. D., Zhu, T., Rannala, B., and Yang, Z. 2018. The spectre of too many species. Syst. Biol. 68:168-181; doi.org/10.1093/sysbio/syy051.

Lehman, P. 2019. The Birds of Gambell and St. Lawrence Island, Alaska. Studies Western Birds 4. W. Field Ornithol., Camarillo, CA.

Lenormand, T. 2002. Gene flow and the limits to natural selection. Trends Ecol. Evol. 17:183-189; doi.org/10.1016/S0169-5347(02)02497-7.

Lyon, B., and Montgomerie, R. 1995. Snow Bunting (Plectrophenax nivalis) and 
McKay's Bunting (Plectrophenax hyperboreus), in The Birds of North America (A. Poole and F. Gill, eds.), no. 198-199. Acad. Nat. Sci., Philadelphia; doi. org/10.2173/bow.mckbun.01.

Maley, J. M., and Winker, K. 2007. Use of juvenal plumage in diagnosing species limits: An example using buntings in the genus Plectrophenax. Auk 124:907-915; doi. org/10.1093/auk/124.3.907.

Maley, J. M., and Winker, K. 2010. Diversification at high latitudes: Speciation of buntings in the genus Plectrophenax inferred from mitochondrial and nuclear markers. Molec. Ecol. 19:785-797; doi.org/10.1111/j.1365-294X.2009.04513.x.

Mallet, J. 2008. Hybridization, ecological races and the nature of species: Empirical evidence for the ease of speciation. Philos. Trans. Royal Soc. B 363:2971-2986; doi.org/10.1098/rstb.2008.0081.

Marshall, D. B., Hunter, M. G., and Contreras, A. L. (eds.). 2003. Birds of Oregon: A General Reference. Ore. State Univ. Press, Corvallis.

Matsuoka, S. M., and Johnson, J. A. 2008. Using a multimodel approach to estimate the population size of McKay's Buntings. Condor 110:371-376; doi.org/10.1525/ cond.2008.8492.

Mayr, E. 1996. What is a species, and what is not? Philos. Sci. 63:262-277; doi. org/10.1086/289912.

Mayr, E., and Short, L. L. 1970. Species taxa of North American birds. Publ. Nuttall Ornithol. Club 9.

Mills, L. S., and Allendorf, F. W. 1995. The one-migrant-per-generation rule in conservation and management. Cons. Biol. 10:1509-1518; doi.org/10.1046/j.15231739.1996.10061509.x.

Mlodinow, S. G., and Bartels, M. 2016. Tenth report of the Washington Bird Records Committee (2010-2013). W. Birds 47:86-119; doi.org/10.21199/WB47.2.1.

Nehls, H. 2014. The records of the Oregon Bird Records Committee through April 2014. Ore. Bird Records Committee; www.orbirds.org/acceptedthroughapril2014.6.pdf.

Nethersole-Thompson, D. 1966. The Snow Bunting. Oliver and Boyd, Edinburgh.

Patten, M. A., and Unitt, P. 2002. Diagnosability versus mean differences of Sage Sparrow subspecies. Auk 119:26-35; doi.org/10.1093/auk/119.1.26.

Paynter, R. A. Jr. 1970. Subfamily Emberizinae in Check-List of Birds of the World (R. A. Paynter Jr. and R. W. Storer, eds.), vol. 13, pp. 3-214. Mus. Comp. Zool., Cambridge, MA.

Polechová, J., and Barton, N. 2015. Limits to adaptation along environmental gradients. Proc. Natl. Acad. Sci. 112:6401-6406; doi.org/10.1073/pnas.1421515112.

Portenko, L. A. 1989. Birds of the Chukchi Peninsula and Wrangel Island, vol. 2. Smithsonian Inst. Libraries and Natl. Sci. Foundation, Washington, DC.

Postma, E., and van Noordwijk, A. J. 2005. Gene flow maintains a large genetic difference in clutch size at a small spatial scale. Nature 433:65-68; doi.org/10.1038/ nature 03083 .

Pyle, P. 1997. Identification Guide to North American Birds, part I. Columbidae to Ploceidae. Slate Creek Press, Bolinas, CA.

Pyle, P. 2008. Identification Guide to North American Birds, part II. Anatidae to Alcidae. Slate Creek Press, Point Reyes Station, CA.

Ridgway, R. 1884. Description of a new Snow Bunting from Alaska. Proc. U. S. Natl. Mus. 7:69-70; doi.org/10.5479/si.00963801.412.68.

Robinson, B. W., Withrow, J. J., Richardson, R. M., Matsuoka, S. M., Gill, R. E. Jr., Johnson, A. S., Lovette, I. J., Johnson, J. A., DeGange, A. R., and Romano, M. D. 2020. Further information on the avifauna of St. Matthew and Hall islands, Bering Sea, Alaska. W. Birds 51:78-91; doi.org/10.21199/WB51.2.1.

Rogers, J. 2005. Identifying McKay’s Buntings. Birding 37:618-626.

Salomonsen, F. 1931. On the geographical variation of the Snow-Bunting (Plectrophenax nivalis). Ibis 73:57-70; doi.org/10.1111/j.1474-919X.1931.tb01504.x. 
Sealy, S. G. 1967. The occurrence and possible breeding of McKay's Bunting on St. Lawrence Island, Alaska. Condor 69:531-532; doi.org/10.2307/1366160.

Sealy, S. G. 1969. Apparent hybridization between Snow Bunting and McKay's Bunting on St. Lawrence Island, Alaska. Auk 86:350-351; doi.org/10.2307/4083511.

Shirihai, H., and Svensson, L. 2018. Handbook of Western Palearctic Birds, vol. 2. Helm, London.

Smith, R. D. 1992. Age determination, wing-feather colour and wing-length change in Snow Buntings Plectrophenax nivalis. Ringing and Migration 13:43-51; doi.or g/10.1080/03078698.1992.9674014.

Smith, R. D. 1996. Racial composition of breeding and wintering Snow Buntings Plectrophenax nivalis in the north-east Scottish uplands. Ringing and Migration 17:123-136; doi.org/10.1080/03078698.1996.9674128.

Stejneger, L. 1884. On the use of trinomials in American ornithology. Proc. U. S. Natl. Mus. 7:70-81; doi.org/10.5479/si.00963801.413.70.

Svensson, L. 1992. Identification Guide to European Passerines, $4^{\text {th }}$ ed. Br. Trust Ornithol., Thetford, England.

Swarth, H. S. 1934. Birds of Nunivak Island, Alaska. Pac. Coast Avifauna 22.

Toews, D. P. L. 2015. Biological species and taxonomic species: Will a new null hypothesis help? (A comment on Gill 2014). Auk 132:78-81; doi.org/10.1642/ AUK-14-138.1.

Vaurie, C. 1956. Systematic notes on Palearctic birds. No. 23. Fringillidae: The genera Emberiza, Calcarius, and Plectrophenax. Am. Mus. Novitates 1805.

Vaurie, C. 1959. The Birds of the Palearctic Fauna. Passeriformes. H. F. and G. Witherby, London.

Wahl, T. R., Tweit, B., and Mlodinow, S. G. (eds.). 2005. Birds of Washington. Ore. State Univ. Press, Corvallis.

Wang, J. 2004. Application of the one-migrant-per-generation rule to conservation and management. Cons. Biol. 18:332-343; doi.org/10.1111/j.1523-1739.2004.00440.x.

Winker, K. 2010. On the origin of species through heteropatric differentiation: A review and a model of speciation in migratory animals. Ornithol. Monogr. 69:1-30; doi.org/10.1525/om.2010.69.1.1.

Winker, K. 2018. Systematics, population genetics, and taxonomy, and their importance for tracking avifaunal change, in Avifaunal Change in Western North America (W. D. Shuford, R. E. Gill Jr., and C. M. Handel, eds.), pp. 453-465. Studies of Western Birds 2. W. Field Ornithol., Camarillo, CA; doi.org/10.21199/SWB3.25.

Winker, K., and Withrow, J. J. 2013. Small collections make a big impact. Nature 493:480; doi.org/10.1038/493480b.

Winker, K., and Withrow, J. J. 2017. Collectively, we need to accelerate Arctic specimen sampling. Arctic Sci. 3:515-524; doi.org/10.1139/as-2016-0037.

Winker, K., Gibson, D. D., Sowls, A. L., Lawhead, B. E., Martin, P. D., Hoberg, E. P., and Causey, D. 2002. The birds of St. Matthew Island, Bering Sea. Wilson Bull. 114:491-509; doi.org/10.1676/0043-5643(2002)114[0491:TBOSMI]2.0.CO;2.

Winker, K., Rocque, D. A., Braile, T. M., and Pruett, C. L. 2007. Vainly beating the air: Species-concept debates need not impede progress in science of conservation. Auk 63:30-44; doi.org/10.2307/40166896.

Winker, K., Glenn, T. C., and Faircloth, B. C. 2018. Ultraconserved elements (UCEs) illuminate the population genomics of a recent, high-latitude avian speciation event. PeerJ 6:e5735; doi.org/10.7717/peerj.5735.

Winters, R. 2013. Snow Bunting: Sexing, ageing and subspecies. Dutch Birding 35:7-14. 


\title{
DISTRIBUTION AND ABUNDANCE OF COLONIAL HERONS AND EGRETS IN CALIFORNIA, 2009-2012 ${ }^{a}$
}

\author{
W. DAVID SHUFORD, Point Blue Conservation Science, 3820 Cypress Dr., \#11, \\ Petaluma, California 94954; dshuford-RA@pointblue.org (current address: 1040 \\ Helen Ct., Petaluma, California 94954) \\ JOHN P. KELLY (current address: 1424 Santa Fe Drive, Encinitas, California 92024) \\ and T. EMIKO CONDESO, Audubon Canyon Ranch, Cypress Grove Research \\ Center, P. O. Box 808, Marshall, California 94940 \\ DANIEL S. COOPER, Cooper Ecological Monitoring, Inc., 255 Satinwood Ave., \\ Oak Park, California 91377 \\ KATHY C. MOLINA, Section of Ornithology, Natural History Museum of Los \\ Angeles County, 900 Exposition Blvd., Los Angeles, California 90007 \\ DENNIS JONGSOMJIT, Point Blue Conservation Science, 3820 Cypress Dr., \#11, \\ Petaluma, California 94954
}

ABSTRACT: As part of an 11-state inventory in the western United States organized by the U.S. Fish and Wildlife Service, we coordinated censuses of 15 species of breeding colonial waterbirds throughout California from 2009 to 2012 . Here we describe the status of the five widespread species of colonial ardeids in California during that period, combining the results of surveys from the air, boats, and ground. Statewide, we estimate 5517 pairs of the Great Blue Heron (Ardea herodias) nesting at 399 sites, 7973 pairs of the Great Egret (Ardea alba) at 182 sites, 1888 pairs of the Snowy Egret (Egretta thula) at 79 sites, 2678 pairs of the Cattle Egret (Bubulcus ibis) at 20 sites, and 2443 pairs of the Black-crowned Night-Heron (Nycticorax nycticorax) at 104 sites. For four of these species, the numbers of colonies and breeding pairs were highest near the coast and in the Central Valley, much lower in the Great Basin, Cascade Ranges, Sierra Nevada, and southern deserts. By contrast, about twothirds of the statewide total of nesting pairs of the Cattle Egret was in the Imperial Valley. The Central Valley was particularly important to the two most numerous species, holding about three-quarters and one half of the state's nesting pairs of the Great Egret and Great Blue Heron, respectively. The survey period coincided with drought, which greatly reduced potential foraging habitat in many regions and may have restricted herons' distribution and depressed their abundance. In the lack of broad-scale surveys during a wet climatic period, no quantification of the effect of drought on herons is possible, though such data are available for other colonial waterbird species. Although the populations of the five herons appear to be stable or increasing, considerable uncertainty in the magnitude and direction of trends remains because of substantial year-to-year variation in numbers of nests and a lack of a robust broad-scale monitoring program suited to these species. Plans for longterm monitoring of ardeids and other colonial waterbirds must account for the large fluctuations in their distribution and abundance over short-term cycles of drought and flood, and factor in the expectation of greater environmental fluctuations with continuing climate change.

Initiatives to promote the conservation of waterbirds throughout North America recognize the importance of inventorying and monitoring. Such work is crucial for determining conservation status, detecting population

\footnotetext{
${ }^{a}$ Appendices 1 and 2 and Tables S1-S5 are available at archive.westernfieldornithologists. org/archive/V51/Shuford-et-al-herons.
} 
trends, assessing habitat health, and evaluating whether management and environmental change are affecting waterbirds (Kushlan et al. 2002). To help fulfill this need, from 2009 to 2012 the U.S. Fish and Wildlife Service coordinated the Western Colonial Waterbird Survey, a broad-scale inventory of 19 species of colonial waterbirds in 11 western states (www.fws.gov/mountainprairie/migbirds/species/birds/western_colonial/index.html). Goals were to document the species composition, size, and location of colonies; estimate minimum regional population sizes for each breeding species; produce an atlas of colonies; and establish a baseline for development of a long-term monitoring program for colonial waterbirds in the West. To date, a lack of adequate data on population sizes and trends of waterbirds has hampered efforts to set population and habitat goals for conservation of these birds in California (Shuford 2014b, Shuford and Dybala 2017).

To ensure adequate coverage of the vast expanse of the West, regional experts organized and implemented the surveys at the state level. In California, Point Blue Conservation Science coordinated surveys of 15 primary species of colonial waterbirds with the extensive aid of many collaborating organizations and individuals (Shuford 2014a). Results of those surveys, with comparisons to prior surveys in the late 1990s, have been published for three tern species and two gull species (Shuford et al. 2016, Doster and Shuford 2018). Here we report on the distribution, number of colonies, and estimated number of pairs nesting in California from 2009 to 2012 for five species of colonial ardeids: the Great Blue Heron (Ardea herodias), Great Egret (Ardea alba), Snowy Egret (Egretta thula), Cattle Egret (Bubulcus ibis), and Black-crowned Night-Heron (Nycticorax nycticorax). Early assessments of herons' status in California were based on anecdotal information, and more recent efforts to quantify the abundance of the state's nesting ardeids have substantial limitations (Belluomini 1978, Schlorff 1982). Nevertheless, we compare the 2009-2012 results to these prior assessments and other broad-scale and regional surveys or monitoring programs extending over multiple years and interpret results on the basis of environmental conditions during the 2009-2012 survey period. We discuss current and future threats to colonial waterbirds in California, and outline how the recent surveys can aid in development of a strategy for monitoring colonial waterbirds throughout the western United States.

\section{STUDY AREA AND METHODS}

\section{Background and Overall Approach}

In organizing statewide surveys, we based the timing and extent of field work on a combination of extensive information gathered on the locations of historical and recent colonies, broad-scale knowledge of wetlands and other potential foraging and nesting habitats from extensive surveys of migrant and breeding shorebirds and waterbirds across much of California since the 1980s (e.g., Shuford et al. 1998, 2006, 2007, Molina and Sturm 2004, Kelly et al. 2006, Shuford 2010), discussions with a broad network of collaborators developed over the years, and, of course, available funding.

Shuford supplemented searches for information on colonies from published and unpublished literature and databases (e.g., California Natural 
Diversity Database), by communicating with various field biologists prior to field work, and by pursuing additional leads when out in the field. These efforts were greatly enhanced by biologists who shared survey data from continuing local or regional monitoring projects or who, under subcontract to our project, conducted or coordinated surveys of one or more species in regions where they had extensive knowledge (and contacts) and/or had conducted surveys in the past.

Because it was not feasible to survey all 15 target species statewide in the same year under the same environmental conditions, we took a regional approach by year. Thus the five species of ardeids discussed here were surveyed by region along with other species of colonial waterbirds. Field work in 2009 focused on selected species that breed mainly in northeastern California; in 2010 on remaining species in northeastern California plus the Black Tern (Chlidonias niger) in the Central Valley; in 2011 on additional species in the Sacramento Valley, Sacramento-San Joaquin River delta, and the northern and central coastal slope (especially the San Francisco Bay area); and in 2012 on the San Joaquin Valley, the coastal slope of southern California, the Salton Sea and Imperial Valley, and the Owens, Mojave, and lower Colorado River valleys. Observers surveyed from the ground, boats, and aircraft. Methods varied by species, colony site, and region depending on the species' nesting habits and local conditions, such as variation in nest substrates, proximity of other nesting species, and accessibility of colony sites. Aerial surveys were particularly valuable for photographing some remote colonies and for visually covering large areas, such as the Central Valley, that would have been impossible to survey adequately by other methods alone.

At each colony, observers tried to count or estimate the number of active nests or nesting pairs for each species. Active nests were defined as those that, at the time of the survey, were attended by an adult(s), held eggs or young, or showed signs of occupancy (e.g., extensive guano) earlier in the current breeding season. Guano-stained nests were counted only during late-season surveys because of the likelihood of pairs from early-season nests later renesting. It was possible in some cases, but not in others, to identify the species responsible for guano-stained nests that were not occupied by adults or young. At four colonies in coastal southwestern California, we apportioned 156 nests of either the Black-crowned Night-Heron or Snowy Egret to species according to the ratio of the identified nests for each species (when the total of identified nests for the two species combined was at least one third the number of unidentified). At seven colonies that did not meet this criterion we were unable to apportion to species the 169 nests of this species pair, leading to an undercount of nests for the two species. At the few sites where it was not possible to estimate the number of nesting pairs by counting nests, we relied on counts of adults and converted these to an estimate of active nests or nesting pairs (see Appendix 2 and Tables S1-S5; see Appendix 1 for glossary of abbreviations used in this supplemental material available at archive. westernfieldornithologists.org/archive/V51/Shuford-et-al-herons).

As much as possible, we timed surveys around peak nesting according to published accounts (e.g., Pratt and Winkler 1985, Kelly et al. 2006, 2007) or the personal knowledge of local experts. To do so, we needed to account for phenology varying by species in multi-species colonies. Individuals within 
a colony may breed asynchronously, or the time of breeding may vary from year to year or from site to site in the same year (e.g., Kelly et al. 2006, 2007). Because logistical constraints usually allowed for only one count per site, we tried to time visits to a colony to optimize counts for all species, given these complications of phenology. Phenological variation was less of an issue where multiple counts were possible. For example, some collaborators identified "peak nesting" for each species as the highest of multiple counts across the season (e.g., Kelly et al. 2007). Others, such as those covering the Sacramento and San Luis National Wildlife Refuge (NWR) complexes and the Sacramento Regional County Sanitation District Bufferlands, provided the raw data from multiple counts from which we identified the time of peak nesting.

\section{Estimating Regional and Statewide Populations}

Although surveys for many of the species addressed by the Western Colonial Waterbird Survey included only the interior of California (see Shuford 2014a for definition), those for herons covered the entire state, including the coast, and hence provide minimum statewide population estimates. To obtain a statewide estimate for each species, we summed the regional estimates, which, with a few exceptions, included the single best (peak) count for each colony during the specific year of the regional survey. The totals approximate the number of nests, which we used as a proxy for the number of nesting pairs (i.e., one nest equals one pair).

\section{Survey Protocols}

In California, observers generally followed the protocols of the Western Colonial Waterbird Survey (Jones 2008). Still, it was necessary to refine these or adopt other methods for situations not covered by that document. Here we summarize the methods by survey region and year; further details of methods are in Appendix 2. We selected census methods and protocols that we judged that would provide the most accurate estimates depending on the species involved, logistical constraints around the colony, the need to minimize disturbance, and the difficulty of covering such a large state.

\section{Northeastern California: 2009}

This study area included all or portions of Siskiyou, Modoc, Shasta, Lassen, Plumas, Sierra, Nevada, Placer, El Dorado, Alpine, and Mono counties. Although much of this sparsely populated region is relatively arid, marshes, lakes, and reservoirs offer extensive potential nesting habitat for waterbirds. These habitats are scattered widely, primarily at elevations from 1220 to 1830 $\mathrm{m}$ (4000 to $6000 \mathrm{ft}$ ) on plateaus, in large valleys, or in basins receiving drainage from nearby mountains. The breeding season of 2009 followed 3 years of drought, as documented by data for the two geographic climate divisions that together compose most of our northeastern California study area (Figure 1A). Consequently, several terminal lakes, reservoirs, or wetlands in this region were nearly or completely dry.

Although field work in this region in 2009 focused on other species of colonial waterbirds that in California breed entirely or mainly in the interior on islands in lakes, reservoirs, or wetlands, we also censused any herons nesting on these islands, those nesting (mainly in marshes) at Clear Lake, Lower 
Klamath, and Tule Lake national wildlife refuges, and colonies of Great Blue Herons at other known or potential colony sites in the region (Appendix 2).

\section{Northeastern California: 2010}

Although the main target species in 2010 were three other widespread or locally numerous breeders not surveyed in this region in 2009, the Eared Grebe (Podiceps nigricollis), Black Tern, and Forster's Tern (Sterna forsteri), we also surveyed for local colonies of herons and ibis. Our efforts focused on valleys of the Cascade Range, Klamath Mountains, and Sierra Nevada, the Modoc Plateau, and the Great Basin desert of all or portions of Siskiyou, Shasta, Modoc, Lassen, Plumas, Sierra, Nevada, Placer, and El Dorado counties. Although precipitation in northeastern California in the winter of 2009-10 was close to the long-term mean (Figure 1A), the previous three years of drought still left many shallow marshes or lakes in the region as small remnants if not dry.

At the two sites in northeastern California where we found egrets and night-herons nesting in 2010, we estimated the number of nesting pairs from a count of adults because our visits were late in the season and/or nests were tucked in dense patches of trees (Appendix 2)

\section{Central Valley: 2011 and 2012}

The Central Valley, surrounded by mountains except at its western outlet into the San Francisco Bay estuary, is about $645 \mathrm{~km}$ long and $65 \mathrm{~km}$ wide. It is divided into the Sacramento Valley, draining southward, the San Joaquin Valley, draining northward, and the Sacramento-San Joaquin River delta, where these rivers converge. The San Joaquin Valley is further divided into the San Joaquin Basin and the usually closed Tulare Basin. Over $90 \%$ of the Central Valley's historic wetlands have been lost (Frayer et al. 1989, Fleskes 2012), and, overall, habitat for breeding waterbirds typically is scarce. The dominant land use in the Central Valley is agriculture, and certain irrigated crops can provide habitats in which breeding ardeids forage. These include the extensive areas of cultivated rice (Oryza sativa) in the Sacramento Valley and smaller areas in the delta and San Joaquin Basin, and flood-irrigated alfalfa (Medicago sativa) throughout the Central Valley. Other potential habitats for foraging herons in the Central Valley include managed wetlands on refuges and duck clubs (limited summer water), basins for storage of flood water or recharge of groundwater (e.g., South Wilbur Flood), reservoirs, stream and river edges, agricultural lands flooded by spring runoff after winters of exceptionally high precipitation, and grasslands and other uplands that provide suitable prey such as small rodents. In the Central Valley most herons nest in riparian woodland, various exotic trees in suburban parks and residential areas, and large stands of eucalyptus in rural areas.

Our censuses of ardeids in the Central Valley spanned two breeding seasons. We surveyed the Sacramento Valley and the delta in 2011. Precipitation in this region in the winter of 2010-11, preceding the 2011 breeding season, was well above average, but was preceded by a winter of average precipitation following three very dry winters (Figure 1A). In 2011, we searched ardeid colonies in the Sacramento Valley and delta by a combination of (extensive) 


\section{DISTRIBUTION OF CALIFORNIA HERON AND EGRET COLONIES}

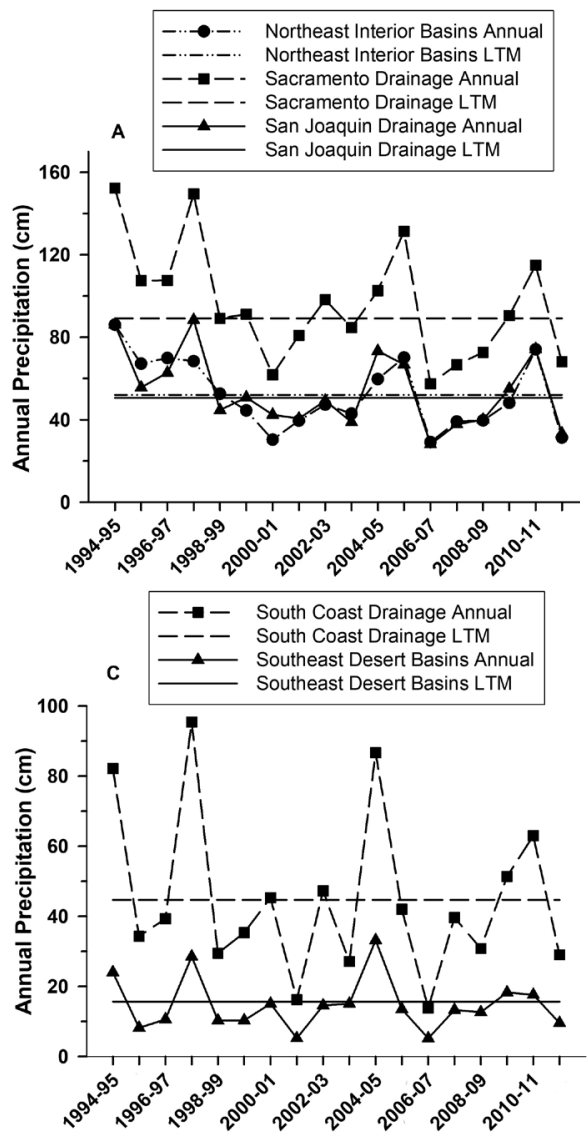

Climate Year
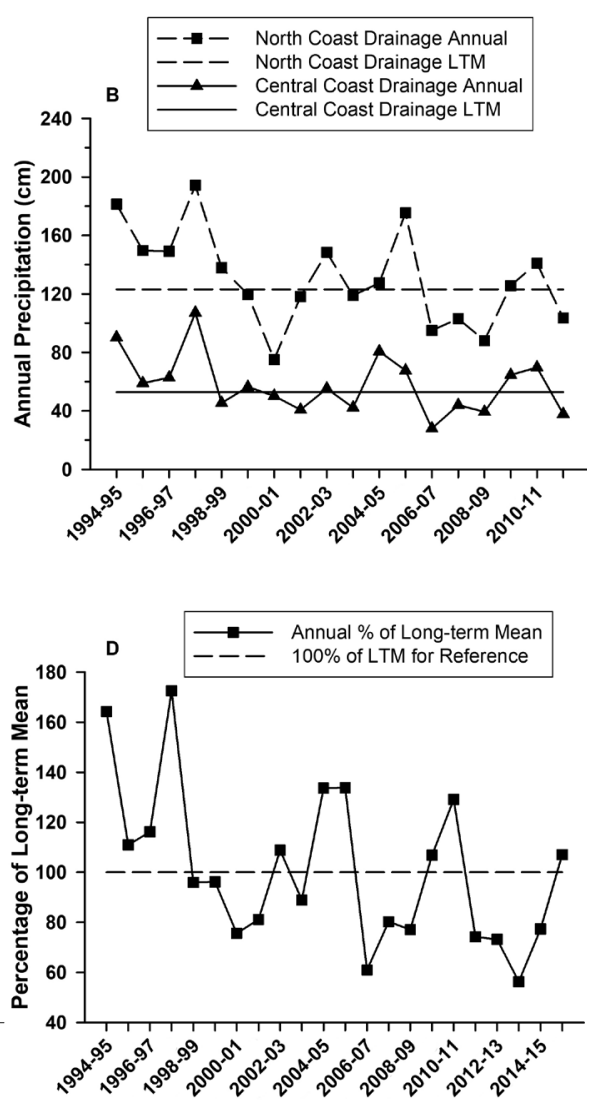

Climate Year

Figure 1. Annual precipitation for the climate years (1 July-30 June) 1994-95 to 2011-12, compared to the respective long-term means (LTM, $n=117 \mathrm{yrs),} \mathrm{for}$ the following climate divisions of California: (A) the Northeast Interior Basins, Sacramento Drainage, and San Joaquin Drainage; (B) the North Coast Drainage and the Central Coast Drainage; (C) the South Coast Drainage and the Southeast Desert Basins; and (D) annual precipitation for all of California, as a percentage of the longterm mean (LTM, $n=119$ yrs), for the climate years 1994-95 to 2015-16. Data from the Western Regional Climate Center (www.wrcc.dri.edu/divisional.html).

aerial, ground, and (limited) boat surveys (Appendix 2). Although most potential habitat was on the floor of the Central Valley, we also looked for colonies along rivers, creeks, wetlands, ponds, and reservoirs in the Sierra Nevada foothills on the east and along east-flowing drainages of the Coast Ranges to the west. 
We surveyed the San Joaquin Valley for ardeids in 2012, locating and counting colonies by the same methods described for the Sacramento Valley and delta in 2011. Although drier than the Sacramento Valley and delta, the San Joaquin Valley is also dominated by agriculture. Habitat for nesting and foraging waterbirds persists mainly at managed wetlands, along rivers and streams, and at water-recharge basins, reservoirs, and other water bodies. The breeding season of 2012 was preceded by a very dry winter; the drought prevailing since 2006-07 had been broken only in 2010-11 (Figure 1A).

\section{Northern and Central Coast: 2011}

This region, from the Oregon border on the north to San Luis Obispo County on the south, includes the intensively developed counties around San Francisco Bay, with its extensive (primarily estuarine) wetlands. In the more sparsely populated counties to the north and south, the land generally rises steeply from the sea and the coast is punctuated with only occasional estuaries and river mouths. In these regions, precipitation in the winter preceding the 2011 breeding season was well above average, in contrast to the prior winter of slightly above average precipitation following three very dry winters (Figure 1B). Surveys in this region were largely ground-based nest counts; aerial and boat surveys were limited (Appendix 2).

\section{Southern Coast: 2012}

The area surveyed for ardeid colonies on the coastal slope of southern California included the coastal plain, interior valleys, and some montane valleys or depressions, all draining west to the Pacific Ocean. This region, much of which is highly developed, encompasses southern Santa Barbara, southern Ventura, southern Los Angeles, Orange, western Riverside, southwestern San Bernardino, and western San Diego counties. The pattern of rainfall in the years preceding the survey of this region paralleled that over most of the rest of California: three very dry winters from $2006-07$ to 2008-09, above-average precipitation in 2009-10 and 2010-11, and a very dry winter in 2011-12 (Figure 1C).

Colonies were largely in plantings of non-native trees near estuaries, wetlands, and reservoirs or other water bodies. Surveys in this region were almost exclusively of nests counted from the ground (Appendix 2).

\section{Salton Sea and Imperial Valley: 2012}

The Salton Sea, in Imperial and Riverside counties, is a large saline lake formed in the early 1900s when floodwaters of the Colorado River overwhelmed water-diversion structures and flowed unconstrained into the Salton Sink for over a year. Its current input consists mainly of tailwater from irrigation of the adjacent Imperial Valley to the south by water imported from the Colorado River. The sea's level is currently on a trajectory of steady decline. Around the south end of the Salton Sea, wetlands of the Sonny Bono Salton Sea NWR and the Wister and Finney-Ramer units of Imperial Wildlife Area (WA) offer additional waterbird habitat. Ardeids also sometimes nest in stands of eucalyptus or other large trees in the Imperial Valley and, more recently, the Coachella Valley. The 2012 breeding season in this region was preceded by a very dry winter in 2011-12, preceded by two winters of above 
average precipitation after three very dry ones starting in 2006-07 (Figure 1C). Precipitation's effect on waterbirds in this desert region appears minimal, however, as inflows to the sea are primarily from agricultural tailwater.

Along with the goals of the broader 11-state project, surveys of colonial waterbirds at the Salton Sea and Imperial Valley in 2012 aimed to provide a basis for comparison with the results of comprehensive surveys in this region in 1999 (Shuford et al. 2000, Molina and Sturm 2004, Molina and Shuford 2013). In this area, observers used a combination of aerial, airboat, and ground surveys (Appendix 2).

\section{Lower Colorado River, Mojave River, and Owens River Valleys: 2012}

Elsewhere in the deserts of southern California, there is limited habitat for nesting ardeids along the lower Colorado River, Mojave River, and Owens River where flood-irrigated crops and pastures, and some adjacent wetlands, allow foraging. Precipitation patterns for these areas were like those for the Salton Sea (Figure 1C). Searches for colonies in this region were largely aerial, supplemented by ground-based counts at newly discovered or previously known colonies (Appendix 2).

\section{Klamath River Country: 2012}

Using prior data on colony locations (from Bob Claypole, California Natural Diversity Database, and John Hunter) and knowledge of potential nesting habitats, from 27 May to 2 June Shuford searched from the ground for active heron colonies in Shasta, (mainly) western Siskiyou, and northern Humboldt counties as detailed in Appendix 2.

\section{DATA SUMMARY AND PRESENTATION}

\section{Ecoregions}

We summarize the distributions of colonies of the five species of ardeids by "ecoregions" as defined in the Jepson Manual (Hickman 1993). The Jepson system is hierarchical, apportioning California among three floristic provinces divided into 10 regions and 23 subregions. The California Floristic Province, the largest, encompasses six regions: Northwestern California, Cascade Ranges, Sierra Nevada, Great Central Valley, Central Western California, and Southwestern California. The Great Basin Province includes the Modoc Plateau and East of Sierra Nevada regions; the Desert Province the Mojave Desert and Sonoran Desert regions. In our results we also distinguish the Sacramento Valley and San Joaquin Valley subregions of the Great Central Valley (Figure 2). In the Jepson system, the Sacramento-San Joaquin River delta is not a distinct subregion but parts of it are included in both the Sacramento Valley and San Joaquin Valley subregions.

\section{Mapping}

The maps showing the distribution and relative size of colonies of each species were created in ArcMap version 10.5.1 (ESRI, Inc.); values for categories of relative abundance were based on natural breaks in the data. 


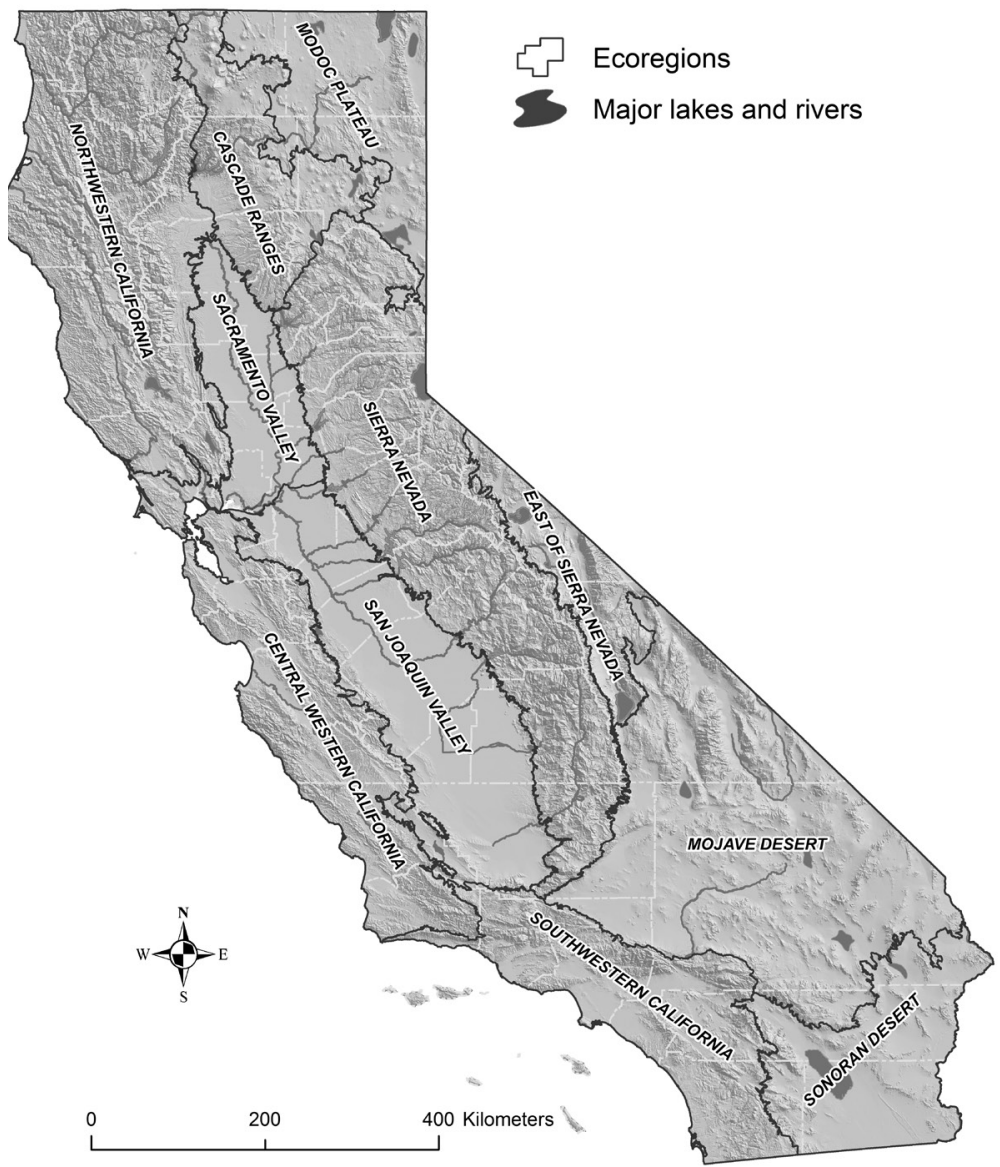

FIgURE 2. Ecoregions-based on the Jepson Manual's geographic subdivisions of California (Hickman 1993) - used for mapping and summarizing data from statewide surveys of waterbird colonies, 2009-2012.

\section{RESULTS}

Here we describe the patterns of distribution and abundance of the five species from 2009 to 2012 by region. Details on the location and size of individual colonies are in Tables S1-S5 (archive.westernfieldornithologists.org/ archive/V51/Shuford-et-al-herons).

\section{Great Blue Heron}

During our study, an estimated 5517 pairs of Great Blue Herons were breeding at 399 sites in California (Table 1). Colony sites ranged in elevation from about $-71 \mathrm{~m}(-233 \mathrm{ft})$ below sea level at the Salton Sea, Imperial County, to $2163 \mathrm{~m}$ (7095 ft) along the upper Owens River, Mono County 
TABLE 1 Estimated Minimum Numbers of Pairs (and Colonies) of Five Species of Ardeids from Broad-scale Surveys throughout California ${ }^{a}$

\begin{tabular}{lccccc}
\hline Years & $\begin{array}{c}\text { Great Blue } \\
\text { Heron }\end{array}$ & Great Egret & Snowy Egret & Cattle Egret & $\begin{array}{c}\text { Black-crowned } \\
\text { Night-Heron }\end{array}$ \\
\hline 1969 & $1737(56)$ & $401(11)$ & $227(4)$ & $0(0)$ & $822(10)$ \\
1970 & $2298(76)$ & $594(20)$ & $303(5)$ & $0(0)$ & $1205(11)$ \\
1971 & $2004(104)$ & $432(13)$ & $525(6)$ & $50(1)$ & $1225(10)$ \\
1972 & $2553(112)$ & $725(21)$ & $985(8)$ & $100(1)$ & $1035(11)$ \\
1978 & $3065(133)$ & $853(30)$ & $3704(12)$ & $7612(7)$ & $939(16)$ \\
1982 & $2859(111)$ & $1245(34)$ & $851(15)$ & $3400(5)$ & $1192(17)$ \\
$2009-2012$ & $5517(399)$ & $7973(182)$ & $1888(79)$ & $2678(20)$ & $2443(104)$ \\
\hline
\end{tabular}

${ }^{a}$ Data for 1969-1982 from Schlorff (1982), for 2009-2012 from this study. See text for cautions warranted in interpreting differences, given the limited information on the thoroughness of the surveys 1969-1982.

(Table S1). Although not the most numerous, the Great Blue Heron was the most widespread species of ardeid in the state, occurring in all 11 ecoregions. The number of colonies was greater than that of any other species (Tables 1 and S1, Figure 3). Over half (54\%) of the Great Blue Heron colonies observed during our survey were small ( $<10$ active nests each; Table S1). Smaller colonies tended to occur in areas far from extensive wetlands or flood-irrigated agriculture, including suburban neighborhoods with fairly limited foraging habitat nearby. Colonies were particularly concentrated in the Sacramento and San Joaquin valleys, which each accounted for about $27 \%$ of all breeding pairs (Table 2). These herons were also numerous in the three coastal ecoregions and at the Salton Sea. Colonies were located mainly in stands of tall trees around coastal estuaries, large inland water bodies, and along major rivers and creeks adjacent to rice fields, other flooded-irrigated forage crops, or wetlands. Less frequently nest sites were on rocky or tule-mat islands, and on artificial structures. Colonies around the periphery of the Central

TABLE 2 Percentage of Nesting Pairs by Ecoregion for Five Species of Ardeids from Statewide Surveys in California, 2009-2012

\begin{tabular}{lccccc}
\hline Ecoregion $^{a}$ & $\begin{array}{c}\text { Great Blue } \\
\text { Heron }\end{array}$ & $\begin{array}{c}\text { Great } \\
\text { Egret }\end{array}$ & $\begin{array}{c}\text { Snowy } \\
\text { Egret }\end{array}$ & $\begin{array}{c}\text { Cattle } \\
\text { Egret }\end{array}$ & $\begin{array}{c}\text { Black- } \\
\text { crowned } \\
\text { Night-Heron }\end{array}$ \\
\hline Northwestern California & 7 & 3 & 7 & 1 & 13 \\
Central Western California & 8 & 8 & 32 & 0 & 14 \\
Southwestern California & 9 & 2 & 20 & 5 & 18 \\
Sacramento Valley & 27 & 56 & 29 & 14 & 36 \\
San Joaquin Valley & 27 & 19 & 6 & 17 & 9 \\
Cascade Ranges & 1 & 1 & 0 & 0 & 0 \\
Sierra Nevada & 5 & 3 & $<1$ & 0 & 0 \\
Modoc Plateau & 1 & 6 & 2 & 0 & 7 \\
East of Sierra Nevada & 1 & 0 & 0 & 0 & 3 \\
Mojave Desert & $<1$ & 0 & 0 & 0 & $<1$ \\
Sonoran Desert & 13 & 2 & 4 & 64 & $<1$ \\
\hline
\end{tabular}

${ }^{a}$ As defined in the Jepson Manual: Higher Plants of California (Hickman 1993; Figure 2). 


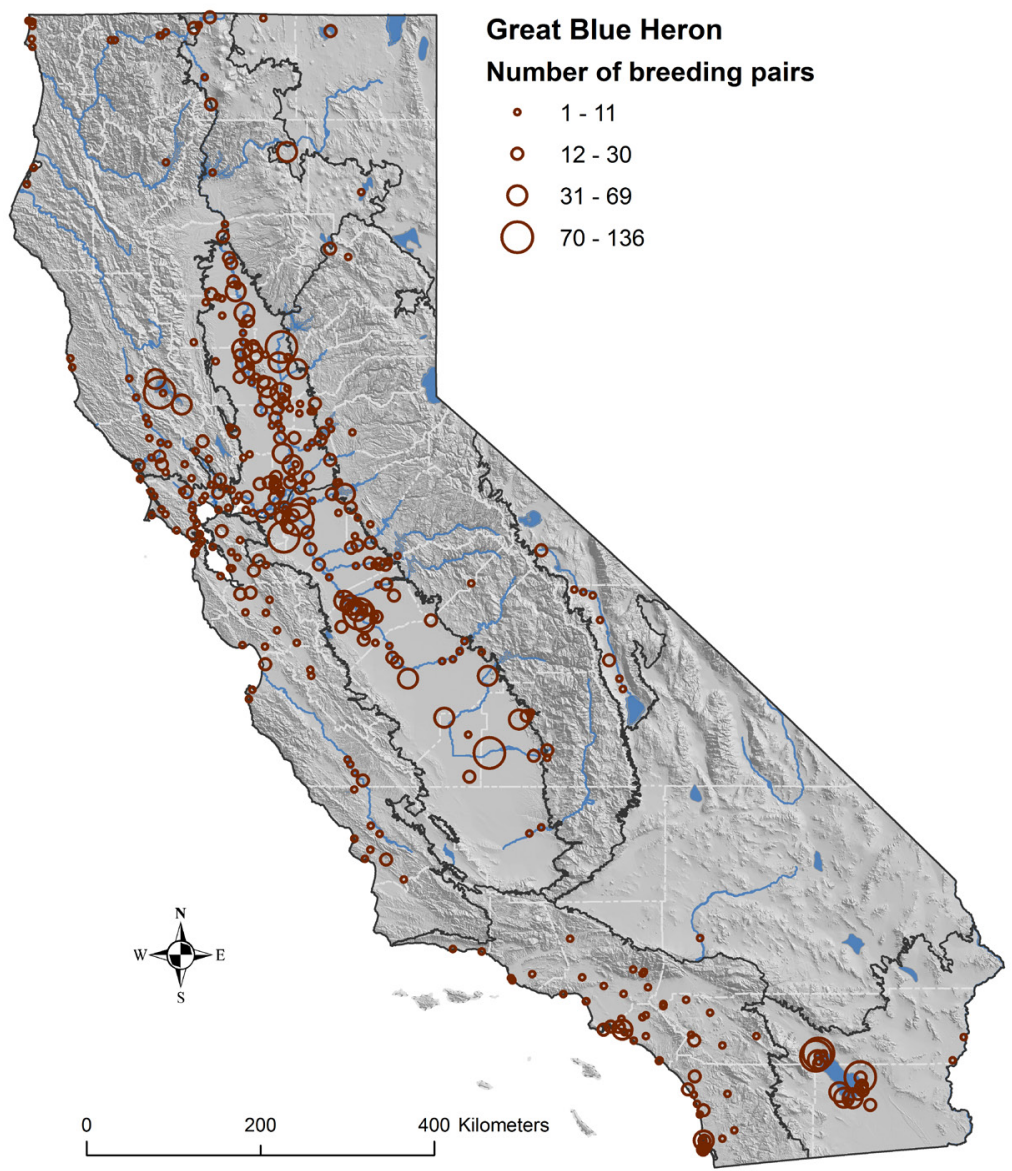

FIgURE 3. Distribution and relative size of Great Blue Heron colonies in California from statewide surveys, 2009-2012 (colony details in Table S1, archive. westernfieldornithologists.org/archive/V51/Shuford-et-al-herons).

Valley and in the adjacent foothills tended to be smaller. Most colonies in the Sacramento Valley and northern San Joaquin Valley were along the main rivers (Figure 4). Most of the largest colonies in southern California were at the Salton Sea (Table S1, Figure 3).

\section{Great Egret}

We estimate a total of 7973 pairs of Great Egrets distributed among 182 colonies (Table 1). These ranged in elevation from about $-68 \mathrm{~m}(-224 \mathrm{ft})$ at the Salton Sea, Imperial County, to $1367 \mathrm{~m}(4484 \mathrm{ft})$ at Clear Lake NWR, Modoc County (Table S2). Great Egret colonies occurred in 9 of 11 ecoregions, being 


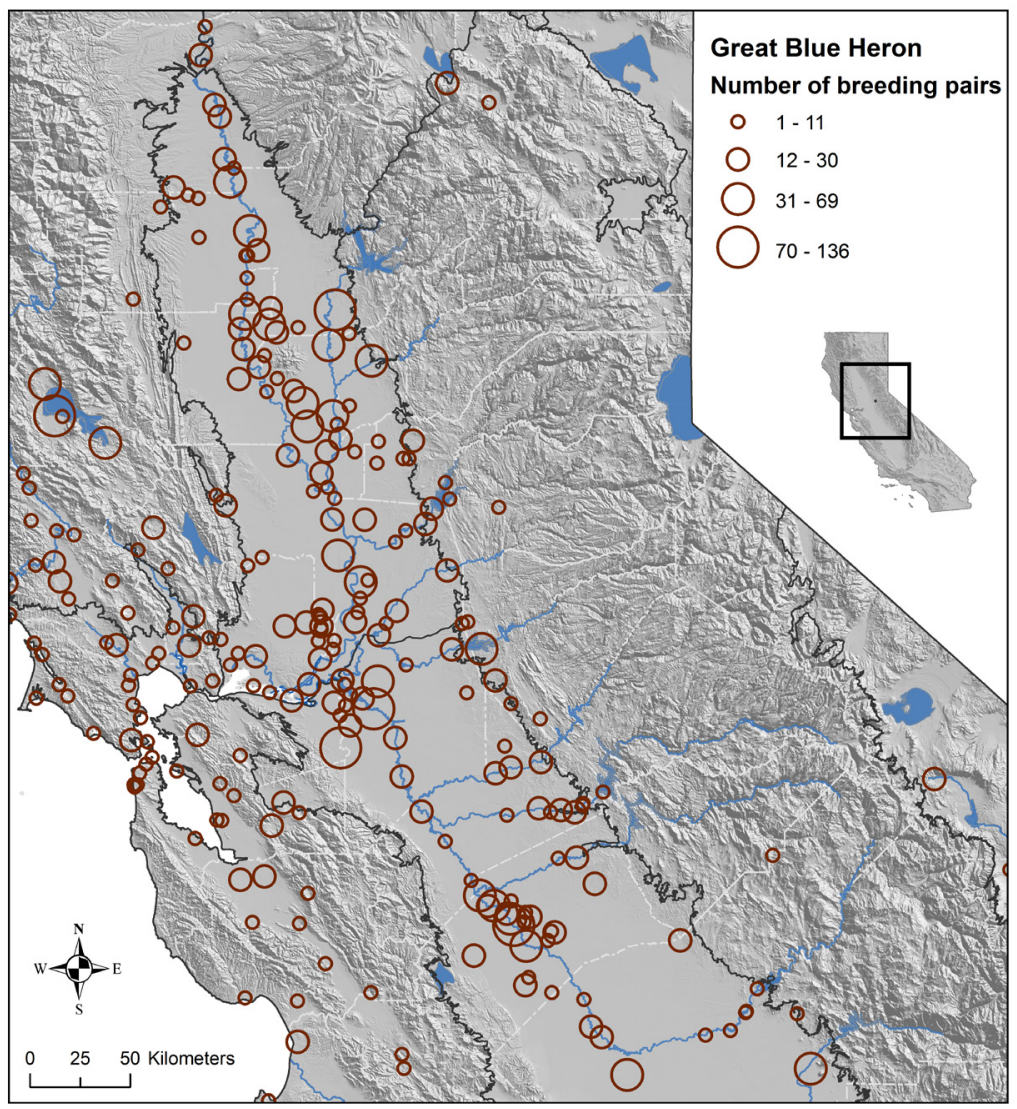

Figure 4. Distribution and relative size of Great Blue Heron colonies in areas of concentration in the Sacramento Valley, Delta, northern San Joaquin Valley, and central coast of California from statewide surveys, 2009-2012 (colony details in Table S1, archive.westernfieldornithologists.org/archive/V51/Shuford-et-al-herons).

absent only in the East of the Sierra and Mojave Desert ecoregions (Table S2, Figure 5). Otherwise the overall distribution of the Great Egret was fairly similar to that of the Great Blue Heron. The Great Egret, however, nested in fewer and generally larger colonies (only $31 \%$ with $<10$ nests each) than the Great Blue Heron. Also, in comparison to the Great Blue, it was more concentrated in some ecoregions and sparser in others (cf. Figures 3-4 with 5-6). Great Egrets were particularly concentrated in the Sacramento and San Joaquin valleys, home to $56 \%$ and $19 \%$, respectively, of the statewide total of estimated breeding pairs (Tables 2 and S2). Like those of the Great Blue Heron, colonies of the Great Egret tended to be smaller toward the periphery of the Central Valley and in the adjacent foothills. Colonies were closely associated with the major rivers 


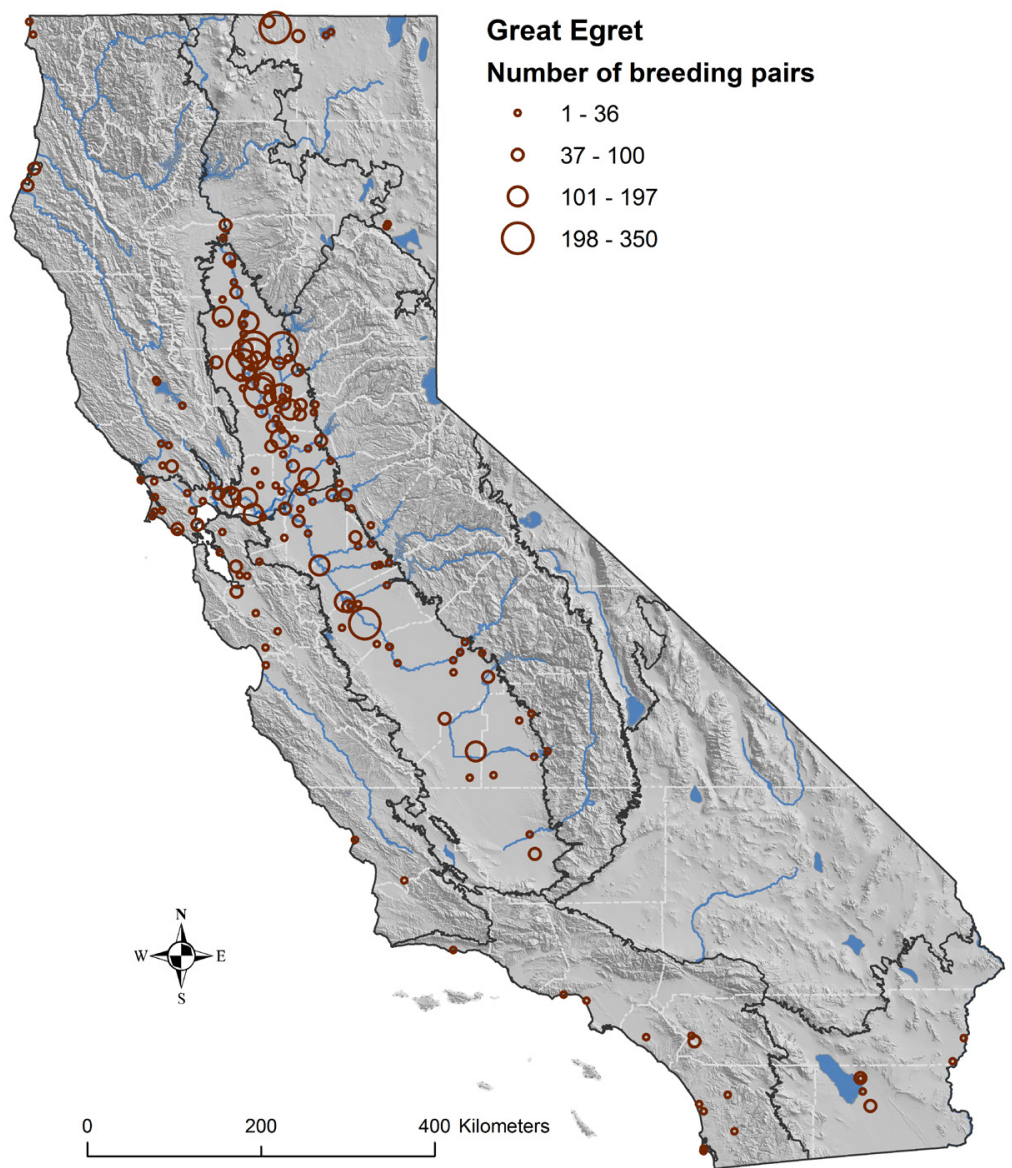

FIgURE 5. Distribution and relative size of Great Egret colonies in California from statewide surveys, 2009-2012 (colony details in Table S2, archive. westernfieldornithologists.org/archive/V51/Shuford-et-al-herons).

(Figure 6). Great Egrets and Great Blue Herons frequently nested in mixed colonies; the two species' nesting and foraging habitats overlap substantially. The Great Egret's particularly high concentration in the Sacramento Valley may reflect its heavy use for foraging of that region's extensive rice fields. Roadside surveys across the Sacramento Valley in the late May and early June 2012 found densities of the Great Egret greater than those of the Great Blue Heron in flooded wetlands, alfalfa, rice, and irrigated pastures (Point Blue unpubl. data).

\section{Snowy Egret}

We estimate that 1888 pairs of the Snowy Egret, distributed among 79 sites, nested in California between 2009 and 2012 (Table 1). This estimate is 


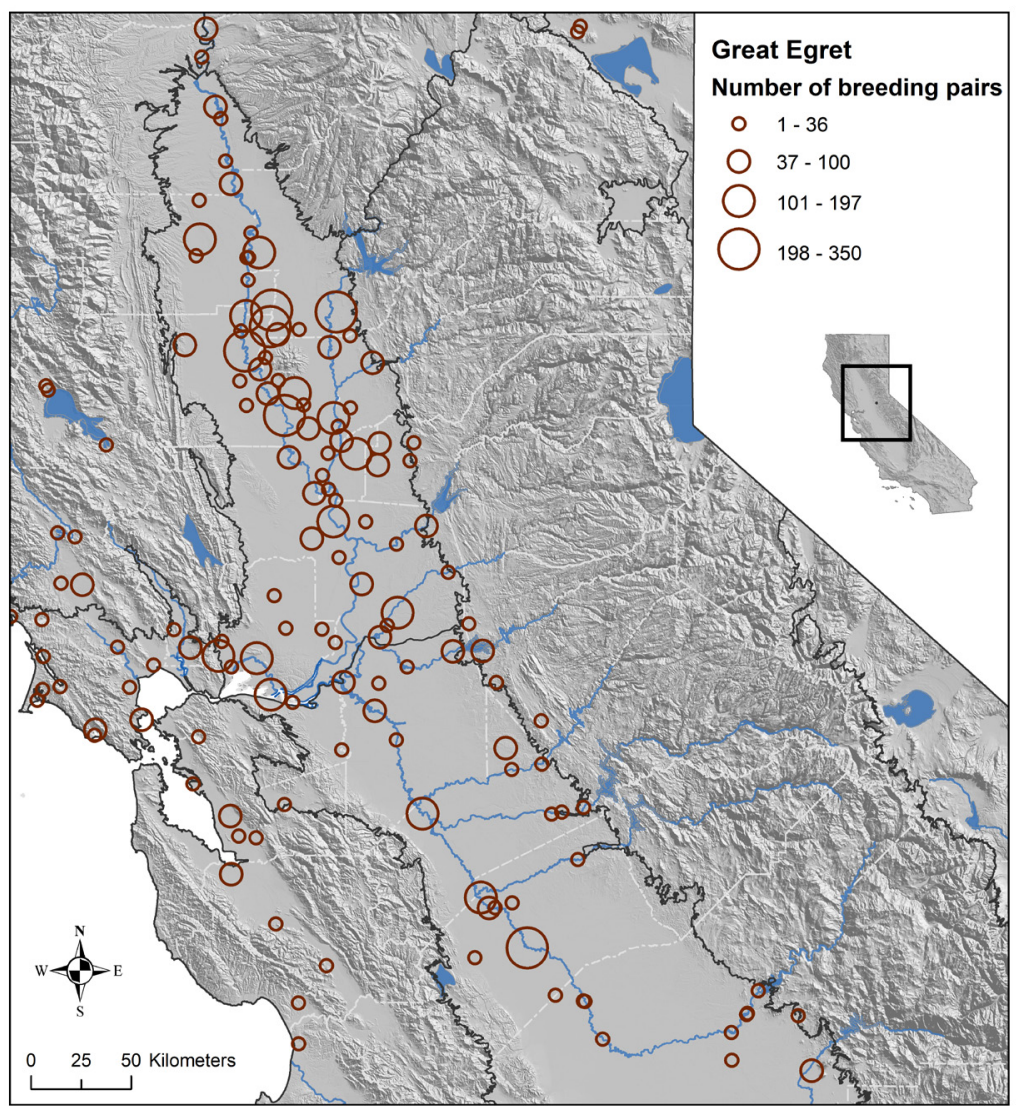

FIGURE 6. Distribution and relative size of Great Egret colonies in areas of concentration in the Sacramento Valley, Delta, northern San Joaquin Valley, and central coast of California from statewide surveys, 2009-2012 (colony details in Table S2, archive. westernfieldornithologists.org/archive/V51/Shuford-et-al-herons).

probably low, as it was not possible to distinguish used nests of the Snowy Egret from those of the Black-crowned Night-Heron or Cattle Egret at several sites surveyed late in the season. Similarly, at the East Hacienda Flood Basin in the southern San Joaquin Valley, large numbers of small white egrets on nests within dense tamarisk or willows could not be distinguished to species during an aerial survey. In addition, because nesting of these species is less synchronized than that of the larger herons (Kelly et al. 2007), peak colony sizes and the number of breeding pairs may have been substantially greater than reflected in our observations. Still, we confirmed Snowy Egret colonies in 8 of the 11 ecoregions. Only in the Cascade Ranges, East of the Sierra, and Mojave Desert ecoregions were they lacking (Tables 2 and S3, Figure 7). Colonies ranged in elevation from about $-68 \mathrm{~m}(-224 \mathrm{ft})$ at the Salton Sea, 
Imperial County, to $1250 \mathrm{~m}(4100 \mathrm{ft})$ at Leavitt Lake, Lassen County (Table S3). The numbers of pairs and colonies of the Snowy Egret were greatest in the San Francisco Bay area, the Sacramento Valley, and southwestern California (Tables 2 and S3, Figure 7). The smaller species-Snowy Egret, Cattle Egret, and Black-crowned Night-Heron-frequently established mixed colonies in trees in residential neighborhoods, parks, or other human-dominated environments, as well as in some more remote locations in the lower strata of trees in which Great Blue Herons and Great Egrets were also nesting.

\section{Cattle Egret}

During our study, an estimated 2678 pairs of Cattle Egrets nested at 20 sites in California (Table 1). Colonies ranged in elevation from about $-68 \mathrm{~m}$ $(-224 \mathrm{ft})$ at the Salton Sea, Imperial County, to $456 \mathrm{~m}(1495 \mathrm{ft})$ at the San Jacinto wastewater-treatment plant, Riverside County (Table S4). Cattle Egret colonies occurred in only 5 of the 11 ecoregions, and the vast majority of egrets were in just 3 (Tables 2 and S4, Figure 8). The Imperial, San Joaquin, and Sacramento valleys held $64 \%, 17 \%$, and $14 \%$ of the statewide total, respectively (Table 2). In the Imperial Valley, most of the egrets were at a single colony at Ramer Lake in the Finney-Ramer Unit of the Imperial WA; the remainder were at two sites at the Salton Sea. Away from the Imperial Valley, most Cattle Egrets nested in mixed-species colonies (mainly with Snowy Egrets and nightherons) in ornamental trees close to human habitation.

\section{Black-crowned Night-Heron}

Our estimate for the Black-crowned Night-Heron is 2443 pairs nesting at 104 sites (Table 1), ranging in elevation from about $-68 \mathrm{~m}(-224 \mathrm{ft}$ ) at the Salton Sea, Imperial County, to $2173 \mathrm{~m}$ (7128 ft) at Laurel Pond, Mono County (Table S5). These night-herons occupied 9 of the 11 ecoregions, but three coastal ecoregions and the two in the Central Valley accounted for $90 \%$ (Tables 2 and S5, Figure 9). Of these, the Sacramento Valley held the greatest proportion at $36 \%$ of the statewide total. Although many night-herons were nesting in mixed-species colonies with small egrets in ornamental trees close to human habitation, many others were nesting in native trees in more isolated settings in mixed-species colonies that also included Great Blue Herons and Great Egrets.

\section{Other Species}

Surveys on the coastal slope and deserts of southern California in 2012 documented breeding of two other species of herons that have spread north into California in recent decades. In 2012, three pairs of the Little Blue Heron (Egretta caerulea) were nesting with Snowy Egrets on the grounds of Sea World, Mission Bay, San Diego County (F. Zern and J. Pea pers. comm.), where it has nested at least intermittently since 1992. Likewise, Yellow-crowned NightHerons (Nyctanassa violacea) nested in 2012 at Sea World (1 nest) and at the Imperial Beach Sports Park adjacent to the Tijuana River estuary, San Diego County (2 nests; F. Zern, J. Pea, and J. Szabo pers. comm.). At least one pair of the Yellow-crowned Night-Heron has nested at the latter site annually since California's first confirmation of the species' successful nesting there in 2006. 


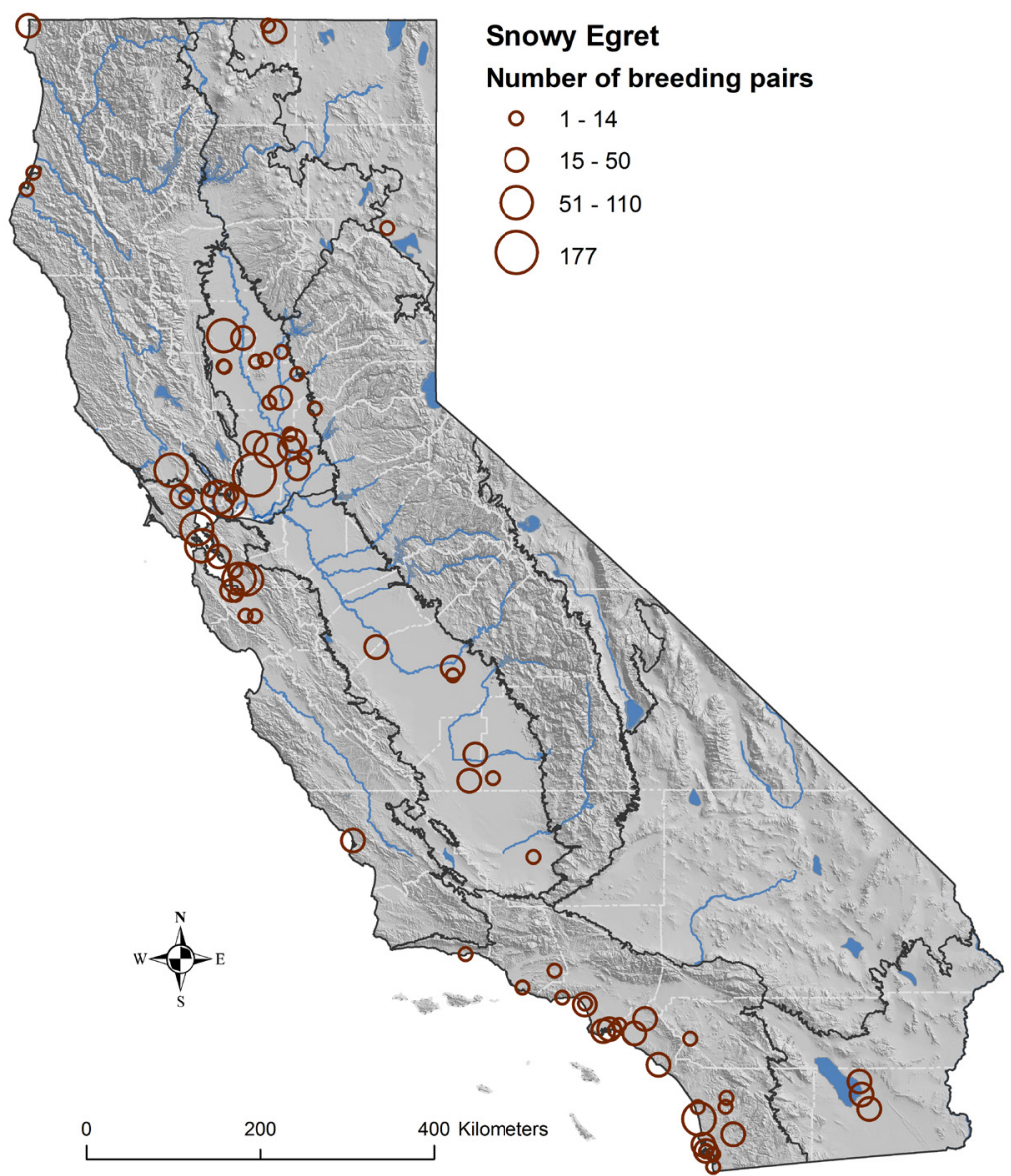

Figure 7. Distribution and relative size of Snowy Egret colonies in California from statewide surveys, 2009-2012 (colony details in Table S3, archive. westernfieldornithologists.org/archive/V51/Shuford-et-al-herons).

\section{DISCUSSION}

\section{Population Trends}

Most colonial ardeids in California experienced historical declines and have since recovered to an unknown degree. The Great and Snowy egrets were decimated by the ravages of plume hunters at the end of the 19th century but began to rebound by about 1910 (Grinnell and Miller 1944). By 1943, the Great Egret was "considered common on the remaining suitable portions of its former range" (p. 58), and the latter was then "fairly common in favored places" (p. 59). These authors also reported numbers of the Great Blue Heron as reduced in "recent years" (p. 56), especially in southern California, and the 
Black-crowned Night-Heron as "formerly abundant, now greatly depleted locally" (p. 60). By contrast, the Cattle Egret was first recorded in California in 1962 and first documented breeding in the state at the Salton Sea in 1970 (120 nests). Its numbers increased rapidly at least until the 1990s (Schlorff 1982, Patten et al. 2003, Molina and Sturm 2004).

Statewide, regional, and local inventorying and monitoring of California's heron colonies did not commence in earnest until the late 1960 s (e.g., Schlorff 1982, Pratt 1983). The California Department of Fish and Game conducted statewide inventories of colonial ardeids in six years from 1969 to 1982 (Schlorff 1982; Table 1). The results are hard to interpret because the limited information on those surveys' methods (Schlorff 1982) suggests they were far less complete than those from 2009 to 2012 (see Methods). Belluomini (1978), however, judged that the steady increase in numbers of nests over the span of at least the first four inventories, 1969-1972, was "as much an increase in the knowledge of heronry locations as an increase in breeding activity." Still, from 1969 to 1982 , the various species' patterns of change in the number of breeding pairs (nests) and colony sites differed (Table 1). The numbers of pairs and colonies of the Great Blue Heron and Great Egret increased overall, but for the Great Blue both metrics dipped in 1982. Overall the number of pairs and colonies of the Snowy Egret increased, with a large spike in pairs in 1978. For the Cattle Egret, one small colony in 1971 and 1972 grew to a peak of 7612 pairs at 7 colonies in 1978 then declined to 3400 pairs at 5 colonies in 1982. Numbers of pairs of the Black-crowned Night-Heron were relatively stable over time while the number of colonies increased modestly. The number of colonies of each species detected from 2009 to 2012 was much greater than in any year from 1969 to 1982 (Table 1), likely reflecting increased survey effort. With respect to the number breeding pairs, however, those for 2009-2012 were much greater than those for 1969-1982 for the Great Blue Heron, Great Egret, and Black-crowned Night-Heron but not for the Snowy and Cattle egrets, whose numbers were more variable (Schlorff 1982).

Regional studies clarify trends in portions of California. Kelly et al. (2006) reported stability or increases in the number of nests of the four main species nesting in the San Francisco Bay region from 1994 to 2005. The Great Blue Heron and Black-crowned Night-Heron showed no significant linear trend, the Snowy Egret showed a marginally significant linear increase, and the Great Egret showed a significant increase, reflecting primarily a sharp increase in 2004 and 2005. From 2001 to at least 2016, the number of Black-crowned Night-Herons nesting in the central and northern San Francisco Bay region declined steeply, at an average rate of $-4.9 \%$ per year $(b=-0.049, P<0.0001)$. Apparently the decrease is related to increases in the frequency of potential nest predators disturbing the colonies (Kelly and Robinson-Nilsen 2011; Audubon Canyon Ranch unpubl. data).

In coastal southern California, the numbers of breeding herons have increased in recent decades, particularly since the 1990s. The increases have been driven largely by the establishment of new colonies in urban settings, though patterns vary by species and subregion. The Great Egret, however, is the one species that has shown a pattern of consistent increase across the region (Unitt 2004, Lehman 2019, Cooper and R. A. Hamilton unpubl. data). In 2012 the total population in southwestern California was about 150 pairs 
or $<2 \%$ of the statewide total (Tables 2 and S2). Although in the last 20 years the number of Snowy Egret colonies in Los Angeles, Santa Barbara, and San Diego counties has increased, in the latter county the increase in colonies has not been accompanied by a clear increase in the species' numbers (Unitt 2004:133, San Diego CBC data fide P. Unitt). Likewise, there is evidence of increases in nesting Black-crowned Night-Herons in Los Angeles County (Cooper and R. A. Hamilton unpubl. data) and at one site in Santa Barbara County (Lehman 2019), but little evidence for changes in the species' abundance in San Diego County (Unitt 2004:144, P. Unitt pers. comm.).

Molina and Sturm (2004) described annual variation in the number of breeding pairs and colonies of five species of ardeids at the Salton Sea from 1986 to 1999. That variation was greatest in the Snowy Egret, Cattle Egret, and Black-crowned Night-Heron, which all reached peaks in 1992 or 1993 when numbers dwarfed those in most other years. By contrast, the number of nesting pairs of the Great Blue Heron was lowest in the early 1990s, and annual variation in the Great Egret was the lowest of the five species. The overall patterns are uncertain, however, as survey effort varied annually, especially prior to 1991 (Hurlbert et al. 2007). Our surveys at the Salton Sea in 2012 found numbers of all five ardeid species lower than in 1999, the year of the last comparable survey (Molina and Shuford 2013).

The applicability of sources of data on ardeid numbers away from colonies is limited. Although all of the five species we address occur in California year round, it is not clear whether numbers in winter are augmented substantially by seasonal influxes of birds from outside of California or how well-suited Christmas Bird Counts (CBC) are to tracking trends in these waterbirds. The Breeding Bird Survey (BBS) gathers data on many species of birds, including ardeids, but its methods are not adapted to surveying colonial waterbirds and undersample marshes (Bystrak 1981, Robbins et al. 1986).

For the periods 1968-2012 and 2002-2012 (i.e., through the last year of our surveys), the BBS showed no significant trends for California for four of the five species we considered (Sauer et al. 2014). The exception was the Great Egret, which showed a significant positive trend in both periods. Although the Cattle Egret showed no significant trends, the BBS data for it were particularly inadequate.

Hurlbert et al. (2007) also assessed variation in the numbers of waterbirds at the Salton Sea, using data from local colony surveys (1987-1999), the two local CBCs (mainly 1968-2004), and the BBS for the western United States (1968-2002). Fluctuations in fish-eating waterbirds, including ardeids, tracked fish populations closely over their two cycles of boom and bust from the 1970s to the early 2000s. Molina and Sturm (2004) concluded that because potentially suitable habitat for colonial waterbirds had remained constant from the mid-1980s to late 1990s, rapid increases in the numbers of nests of some waterbirds, including the Great Blue Heron but no other ardeid, in the mid- to late 1990s were best explained by changes in the availability of food rather than of nest sites (but see under Threats below).

For the period 1978-2014, Pandolfino and Handel (2018) compared trends of various species, including ardeids, on CBCs in the Central Valley with those from the BBS for all of California and the West. The Great and Snowy egrets both showed significant increases on both the Central Valley 


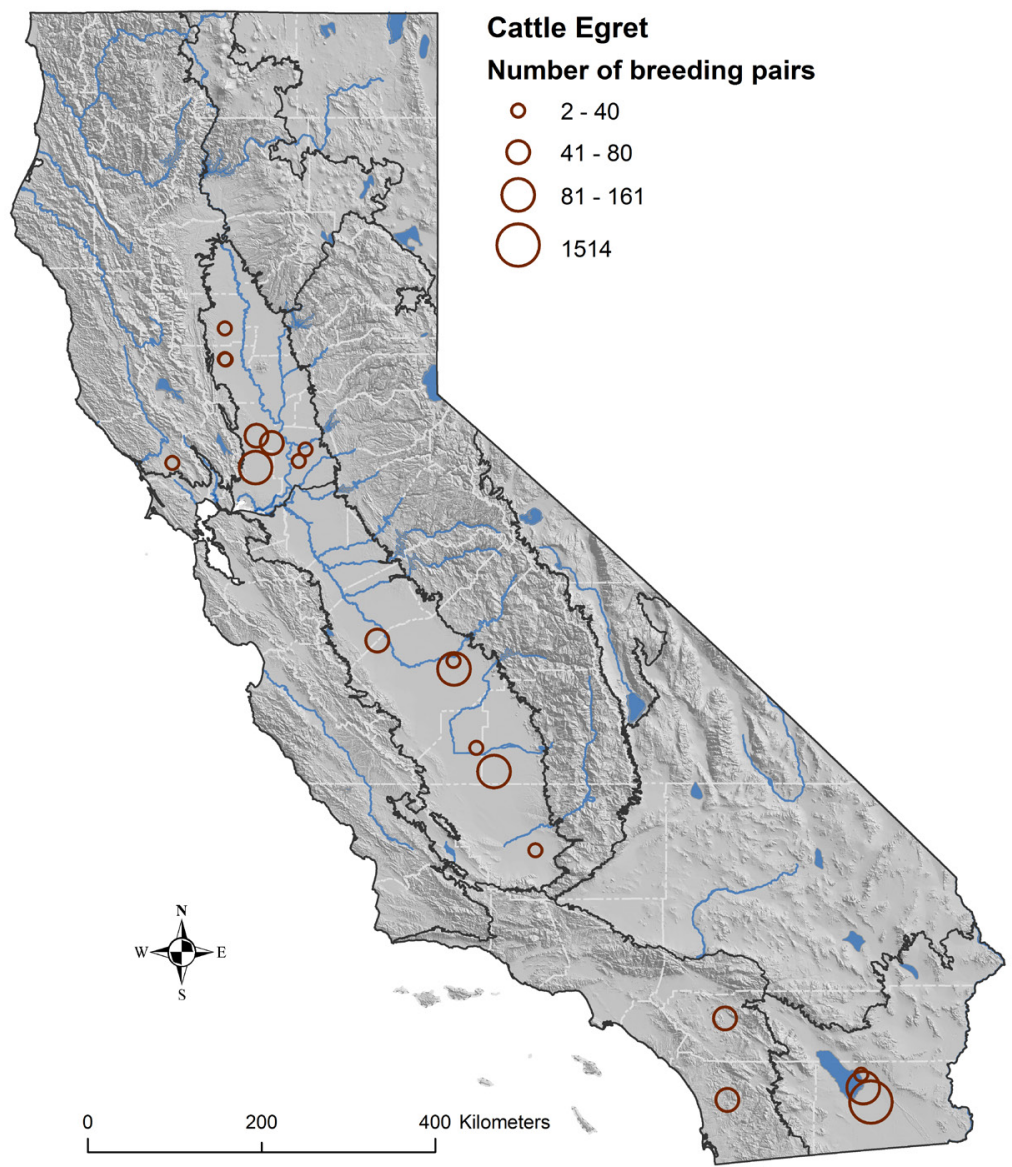

FiguRE 8. Distribution and relative size of Cattle Egret colonies in California from statewide surveys, 2009-2012 (colony details in Table S4, archive. westernfieldornithologists.org/archive/V51/Shuford-et-al-herons).

CBCs and California BBS routes. By contrast, the Great Blue Heron showed a small but significant decrease on $\mathrm{CBCs}$ and no significant trend on the BBS. For the Black-crowned Night-Heron there was no significant trend in either set, and for the Cattle Egret the lack of a significant trend on CBCs was paired with an increasing but weakly supported significant trend on the BBS.

It is possible that some of the patterns Pandolfino and Handel (2018) described from Central Valley CBCs may in part reflect changes in distribution rather than in abundance. Fleskes et al. (2018) analyzed trends in the abundance and distribution of waterfowl and their habitats in the Central Valley from 1973 through 2000. During this period, wetlands increased throughout the Central Valley. By contrast, the extent of rice fields flooded after harvest 


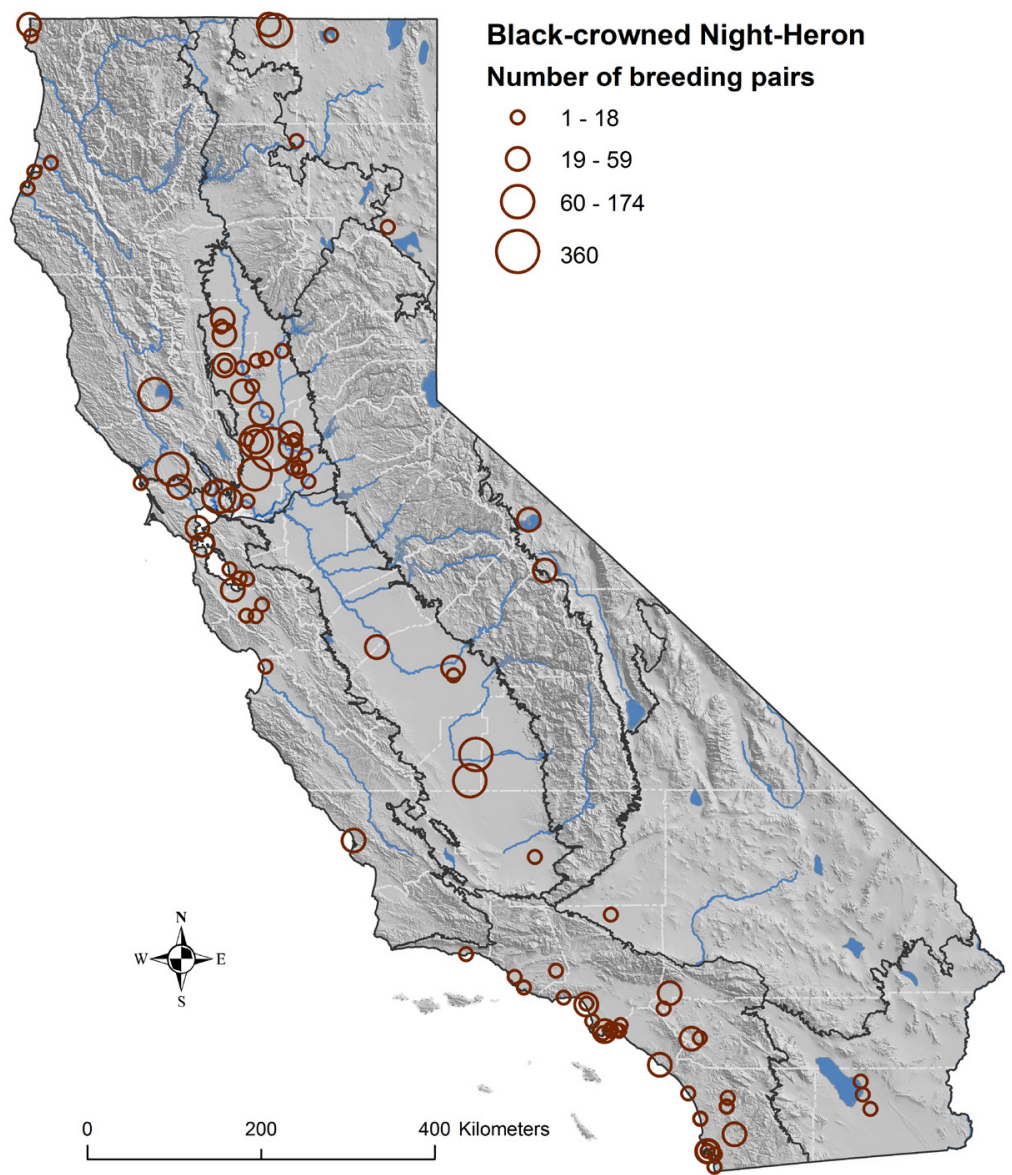

Figure 9. Distribution and relative size of Black-crowned Night-Heron colonies in California from statewide surveys, 2009-2012 (colony details in Table S5, archive. westernfieldornithologists.org/archive/V51/Shuford-et-al-herons).

increased greatly to the north in the Sacramento Valley but decreased to the south in the San Joaquin Valley. The result was a pronounced shift in the availability of winter waterfowl habitat, and of the waterfowl themselves, to the north. Some heron species might have shifted north as well. Although numbers of Great Blue Herons on CBCs in the Central Valley did not increase, this species' apparent stability might in part reflect the Great Blue's relying less on rice fields than does the Great Egret; in 2012 we found the egret's density in rice fields to be greater than that of the heron (Point Blue unpubl. data). The sample of CBC circles Pandolfino and Handel (2018) analyzed was more heavily weighted to the Sacramento Valley, where most of the Central Valley's rice is grown, than to other subregions, so the Great Egret might be 
overrepresented because of disproportionate coverage of areas where rice cultivation was expanding.

Given the limitations of all these studies, there is still considerable uncertainty in the direction and magnitude of changes in populations of California's breeding herons over the last 40 to 50 years. The clearest case is that of the Cattle Egret, which increased rapidly soon after the initial discovery of a colony of about 120 pairs at the Salton Sea in 1970 (Patten et al. 2003). By 1978 the Imperial Valley hosted over 7000 breeding pairs (Belluomini 1978), and in 1992 it reached a peak of about 30,000 pairs (Molina and Sturm 2004). From 1986 to 1999 , however, numbers (of uncertain accuracy) varied greatly from one year to the next, often by many thousands (Molina and Sturm 2004). Thus annual variation rather than a downward trend could account for the 2012 estimate for the Imperial Valley/Salton Sea being only 25\% of the total in 1999, when last surveyed (Molina and Sturm 2004, Molina and Shuford 2013). Water conservation mandated by recent transfers of water from the Imperial Valley to San Diego and other coastal cities may also have reduced the suitablility of this valley to the Cattle Egret, given its dependence there on irrigated agriculture for foraging. Notably, from 2003 to 2011, an average of 85,869 acre-feet of water was saved annually by fallowing of fields and increased efficiency of irrigation (Velasco 2013). Alternatively, it may simply be that after peaking the number of Cattle Egrets nesting in that region has dropped to a lower level around which it is currently fluctuating.

Data for the other four species suggest their numbers have been stable or increasing in recent decades (Schlorff 1982, Molina and Sturm 2004, Kelly et al. 2007, Sauer et al. 2014, Pandolfino and Handel 2018). Among these, however, the Great Egret is the only species that shows strong evidence of an increasing population in California. Annual variation for the Snowy Egret and Black-crowned Night-Heron may be so great that it masks any underlying long-term trends, as it does for the Cattle Egret in recent years.

\section{Elevational and Latitudinal Ranges}

The upper elevational limits of breeding of each of the five species in California was closely associated with the northern latitudinal limit of its breeding in western North America. The Great Blue Heron and Black-crowned NightHeron, which each bred up to about $2160 \mathrm{~m}$ (7100 ft) in California, breed the farthest north (Dunn and Alderfer 2017). By contrast, the Cattle Egret bred up to just $456 \mathrm{~m}$ (1495 ft) in California, and it does not breed as far north as the other four species. The Great and Snowy egrets are intermediate in these limits with respect to the other species.

\section{Climatic Variation}

Over the last 20 years California's climate has varied widely, from very wet to extremely dry. Surveys of the state's interior from 1997 to 1999, a period with precipitation well above average (Figure 1D), addressed some colonial waterbirds but not herons (Shuford 2010). Conversely, the 2009-2012 surveys, which did include them, overlapped with the extended drought that began in 2006-07. Despite being interrupted by one year of heightened precipitation ( $129 \%$ of long-term mean), this dry period persisted four years beyond the completion of our surveys in 2012 (Figure 1D). The dry period 
from 2011-12 to 2015-16, alone, is considered the most severe statewide drought in the historical record (Swain 2015, Wang et al. 2017). Furthermore, the 2000-2018 drought in southwestern North America, including California-driven by natural variability superimposed on drying from anthropogenic warming-was the second driest 19 -year period since 800 CE (Williams et al. 2020).

The lack of long-term monitoring of the populations of colonial waterbirds in most of the interior of California limits the conclusions we can draw on the drought's effects. But data for this region for a set of species inventoried both 1997-1999 and 2009-2012 provides some potentially valuable insights (Shuford 2014a, Shuford et al. 2016, Doster and Shuford 2018). In the latter period, breeding populations of the Ring-billed Gull (Larus delawarensis), California Gull (L. californicus), Caspian Tern (Hydroprogne caspia), Black Tern, and Forster's Tern were greatly reduced in northeastern California. Those of the latter three species were also much reduced in the Central Valley and so throughout the inland portion of their California breeding ranges. Drought likely affected herons and other waterbirds unsurveyed in one or both periods. Effects on most species, whether monitored or not, undoubtedly intensified after 2012, as the drought continued four more years. Kelly and Condeso (2014) investigated the effects of the amounts and volatility (storminess) of seasonal rainfall on changes in the numbers of heron nests in the San Francisco Bay area, 1991-2010. They found that the number of nests of the Great Blue Heron and Great Egret in this region declined or grew more slowly after winters of both wetter- or drier-than-average rainfall. Those of the Snowy Egret and Black-crowned Night-Heron declined or grew more slowly immediately after spring (nesting) seasons when the volatility of rainfall was greater than usual and two years after winters when this measure was greater than usual. From this they predicted regional declines in the growth or resilience of heron population should the amount and volatility of rain in northwestern California increase. Furthermore, future effects may be even greater, given projections of 21st-century increases in the frequency of wet extremes and smaller increases in dry extremes (Swain et al. 2018).

\section{Accuracy and Challenges of Nest Counts}

It is often difficult to determine how close counts or estimates of the numbers of nests or breeding pairs of ardeids are to the actual number present. Many factors can influence the counts' accuracy, such as the size of the area to be searched and availability of resources. Cycles of wet and dry affect habitat availability in different regions from year to year, complicating comparisons when colonies in different regions are surveyed in only one year during a multi-year survey period. The number of nests or adults present (or visible) varies through a breeding season, hindering comparisons when counts of different colonies span an extended period within that season. The detecability of nests and adults varies with the surrounding landscape, nest substrate or vegetation type, the species' behavior and color, observers' experience, etc. We were not able to quantify how such factors might have influenced the accuracy of counts from 2009 to 2012.

Ideally, all surveys should be conducted in a single year, as colonies' locations and size can change as water levels and the availability of nest sites 
or foraging areas fluctuates annually. Our regional approach of spreading surveys over several years encompasses potentially substantial unknown annual variation in colonies' size and distribution. However, annual variation in colony-site selection and use largely reflects the adaptive responses of herons and egrets to the local landscape within their foraging range. Local annual responses are substantially masked (or averaged out) at larger scales of measurement (Kelly et al. 2018). Thus our analysis of regional or multiregional differences in the numbers of nesting herons is unlikely to be affected strongly by smaller-scale processes and colony-site differences between years. Nonetheless, unknown interregional shifts of the population could confound interpretation of the results of a four-year survey partitioned among regions.

Regardless, summing counts taken over more than one year, as we have done, is often the only feasible way to estimate a total population size when the goal is a census of multiple species distributed among large numbers of colonies spread over a broad area (e.g., see Carter et al. 1992 for California seabirds). In just one of four years from 2009 to 2012 was precipitation above average, which likely reduced the year-to-year variation in numbers of nests within that interval. Still, it seems likely that summing the regional estimates yielded a minimum value for the statewide populations of the five species, as very dry conditions in two years may be expected to have depressed the numbers. Furthermore, given the huge area we surveyed, we undoubtedly missed some colonies.

Timing the counts to the peak of nesting is always desirable. This is not always easy to do, however, particularly for species such as the Black-crowned Night-Heron and Snowy Egret for which the timing of peak nesting may vary considerably, annually or by site in the same year (Kelly et al. 2006). For such species, it is preferable, if feasible, to take multiple counts across the season. Late-season counts may include so many used nests that it may not be possible to assign them to species by the ratio of nests of these species still active in the colony. For some seabirds, however, peak nest counts can substantially underestimate the number of breeding pairs (Seavy and Reynolds 2009). It is unclear to what degree this potential bias affected our estimates of the numbers of nesting herons. Nevertheless, our counts are indices of the population so should be comparable to future estimates if surveys follow the same methods, are done at the same time in the nesting cycle, and are done under reasonably similar environmental conditions.

Species that nest on varied substrates may be relatively easy to count on one substrate but not on another. For example, nests of the Great Blue Heron on open islands are straightforward to count from aerial photos, but this technique works poorly when the birds are nesting in trees with leafy canopies. In such cases visual counts of nests from the air or ground are preferable.

When nests are partially screened by vegetation the accuracy of nest counts may vary with the vegetation type. At the extreme end, species like egrets and night-herons may nest in tall marsh vegetation where few if any nests are visible from the periphery of the marsh. In such cases, numbers of nests can be estimated from counts of the number of adults flying out of the colony. Converting numbers of adults to an estimate of pairs, however, introduces uncertainty, as the proportion of adults remaining at the nest site may vary over the course of the breeding season. Using a conversion factor 
implies the assumption that all adults present are breeding and their nests are at the same stage of the breeding cycle. The latter in particular is a risky assumption because the timing of nesting in a colony may vary considerably by species, by individual within a species, and from year to year (Kelly et al. 2006, 2007, Hothem et al. 2010).

A more typical challenge is obtaining good counts of nests in leafed-out trees. The foliage may obscure a nest, or an entire tree may block the view of more distant trees in which herons are nesting. Observers may compensate by surveying from multiple vantage points, but such options may be limited by impenetrable vegetation or restricted access to private property. For earlynesting species like the Great Blue Heron it may be possible to count nests before the trees are well leafed out. But this often is just a partial solution. In multi-species colonies other species may start nesting later when trees are fully leafed out. Such seasonal variation in foliage is not an issue for colonies in evergreen trees.

Aerial surveys can provide a good overview of a colony, particular those of the Great Egret and Great Blue Heron, which tend to nest at or near the top of the canopy. From a fast-moving plane, however, the time available for counting nests is short. This problem can be alleviated somewhat if the colony can be circled several times. Also, the ease of locating a colony on an aerial survey depends on the colony's size and species composition. Large colonies, particularly those dominated by white-plumaged egrets, are much easier to detect than are smaller colonies, particularly those with just a few pairs of drab-plumaged herons. Censusing arboreal colonies by means of photographs is challenging because nests may be within multiple layers of the canopy, making it hard to piece together photos of a three-dimensional object taken from various angles. During aerial surveys, it is usually not feasible to photograph large numbers of colonies because of the costs of additional flight time and photo counting. Our study entailed many days of aerial surveys, particularly for colonies along the rivers of the Central Valley. We initially contemplated making rough counts of the nests from the plane and then going back on the ground to make a more leisurely and accurate count. It was often not possible, however, to get close to colonies on the ground because of private property, impenetrable vegetation, or sloughs to cross. Or, just a portion of the colony might be visible from the only access point. In such cases, mapping the locations of nests is helpful, as is watching the colony long enough that young may stand up in nests that were not initially visible, or adults returning to the colony may reveal nests when they land.

To facilitate comparisons of the results of future statewide inventories with ours, we recommend the use of the most accurate method of counting for each species, nest substrate, and time of the season and, insofar as possible, replication of our protocols and methods. Modifications may, of course, be needed or desirable depending on conditions at the time of a future inventory or advances in knowledge or technology that may improve surveys' accuracy over what is currently possible.

\section{Future Monitoring}

One of the primary goals of the Western Colonial Waterbird Survey was to establish a baseline for long-term monitoring of these species throughout 
the western United States (Seto 2008). Such an inventory is a prerequisite for a long-term monitoring program, as are standardized protocols and methods for surveying colonial waterbirds (e.g., Steinkamp et al. 2003, Jones 2008). Steinkamp et al. (2003) emphasized thinking beyond measuring change in numbers over time so that the information collected can be used effectively to improve management. They noted that the geographic scale and objectives will greatly influence the design of the program. For example, is the main objective to detect population declines that may require action to remediate, or is the main interest in documenting colony locations? Another key element is deciding the scale on which the program will focus for evaluating the status and trends of waterbird populations. Any monitoring at the scales of the state or the West as a whole will require collaboration with groups that focus their current monitoring at smaller scales. Ideally, protocols and methods can be standardized, modified, or adapted so that trends can be accurately assessed, and compared geographically, for the range of scales important to collaborators.

Other key decisions are whether particular species or populations deserve priority for monitoring, whether to monitor all populations or just sample or select populations, the frequency of surveys within and in successive years, and the magnitude of change targeted for detection with reasonable precision over a specified period (Steinkamp et al. 2003). The Pacific Flyway Council $(2013,2018)$ considered these factors when prioritizing the monitoring of western populations of the Double-crested Cormorant (Phalacrocorax auritus) and American White Pelican (Pelecanus erythrorhynchos) in response to predation of these species on fish of conservation concern or economic or social value.

In California, decisions on a frequency for monitoring of ardeid colonies should take into account the state's great annual variation in precipitation, the substantial annual variation in the breeding numbers of some species, and the rates of abandonment of old and establishment of new colonies. We recommend surveys at short intervals, ideally annually, as the extent of wetlands or other water bodies may vary markedly over short periods, the extent of flood-irrigated crops in which herons forage may decrease substantially during severe droughts, and the variability of precipitation may increase with climate change (Swain et al. 2018). While the desired levels of precision and ability to detect trends should inform sampling effort, resource limitations may dictate survey frequency.

Given that attempts to inventory all heron colonies in California on a regular basis are not feasible, any statewide monitoring program will need to adopt a statistically robust sampling framework. This should reduce sampling error resulting from spatial and temporal variation in densities of waterbirds influenced by habitat or other factors, variability in colony attendance by the stage of the nesting cycle, and differences in the probability of detecting birds by species and habitats and over time (Steinkamp et al. 2003).

Any monitoring program for ardeids in California can draw lessons from efforts at the local and regional level (e.g., Molina and Sturm 2004, Kelly et al. 2006), from the California-wide surveys 1997-1999 (Shuford 2010) and 2009-2012 (Shuford 2014a), and from the recent multi-state surveys (Cavitt et al. 2014). The results of experiments with unmanned aerial drones for 
wildlife surveys (e.g., Ogden 2013) suggest that the way biologists monitor waterbirds may change rapidly in coming years.

Even a well-designed and -executed monitoring program may falter without institutional support to maintain training of biologists and volunteers to survey in a standardized manner. The program's administration must coordinate the collection and analysis of the data, disseminate the results, and instigate research and management when action is warranted.

\section{Threats to Waterbirds}

Colonial waterbirds face a host of threats, which have changed over time. But the greatest threat to these birds in California currently is the combination of habitat loss, degradation, and fragmentation, driven by an expanding human population. Other threats to waterbirds in California include increasing competition for water from municipal and agricultural interests; changing or detrimental agricultural, municipal, or industrial practices in altered habitats; poor or toxic water quality and oil spills; diseases; subsidized and introduced predators; invasive species; human disturbance; conflicts with human interests; interspecific conflicts; and the long-term effects of climate change (Shuford 2010, 2014b).

California's drought from 2006 to 2016 emphasizes the importance of reliable water supplies for wetlands and irrigated crops that are prime foraging habitats for waterbirds. Although waterbirds are adapted to periodic droughts, there are, of course, limits to their adaptability. The effect of precipitation may cut both ways, however, as Kelly and Condeso (2014) reported that on the central California coast both too much or too little rainfall, or increases in the volatility of that rainfall, are likely to depress the growth rates of heron populations. It remains to be seen if these patterns are similar in the interior, where foraging habitats tend to be more ephemeral, than on the coast, where herons forage predominantly in tidal wetlands.

Furthermore, water diversions for human uses may increase the frequency of predators' access to heron nests if water levels drop or sites dry up until islands, marshes, or emergent trees and snags are no longer surrounded by water. Unless conservation of water improves greatly, competition for water will only increase as the human population expands. In agriculture, ironically, water-conservation measures may decrease the value of some crops to foraging waterbirds if there is a move to drip or sprinkler irrigation of crops that are currently flood irrigated.

Areas of California where overallocation of water supplies has been a particular problem in recent years include the Klamath Basin, Central Valley, and Salton Sea (summaries in Shuford 2010). Some of the potential threats previously identified in these regions have been realized. By 2014, the steady decline in the levels of the Salton Sea had forced the abandonment of the huge colony of Double-crested Cormorants and smaller colony of Great Blue Herons on Mullet Island; the cormorant colony had been by far the largest in the interior of California (Shuford 2014a) and the second largest in the Pacific states (Adkins et al. 2014). Similarly, some nearshore snags herons and egrets formerly used were out of the water in 2012 and no longer suitable for nesting; as of 2020, many snags have fallen and remaining ones are subject to disturbance as water levels have receded further (T. Anderson and S. Przeklasa née 
Haynes in litt.). Also, the Salton Sea's increasing salinity as its water levels drop will ultimately decimate the fish prey crucial to nesting waterbirds. Since our surveys in 2012 the decline in the sea's level has accelerated (waterdata.usgs. gov/ca/nwis/dv?referred_module=sw\&site_no=10254005) and is projected to continue. Although the California populations of five species of ardeids appear to be stable or increasing, vigilance is essential as threats like these may increase with an expanding human population and changing climate.

\section{ACKNOWLEDGMENTS}

For a project of this scope, the individual and organizational contributions were synergistic and their worth far greater than the sum of the parts. Our debt to those who helped in any capacity is deep and wide. For starters, we thank the many people (listed individually in Shuford 2014a) who provided valuable information or advice, help on field surveys, data from their own surveys, logistical support, or access to private or restricted public lands, without which this study would not have been possible.

The following individuals conducted, coordinated, or otherwise made major contributions to surveys of particular species or geographic areas of the state: David Haines and Phil Henderson (northeastern California in 2010 and 2009, respectively); John Beckstrand and Dave Mauser (Klamath Basin refuges in 2009); Caitlin Robinson-Nilsen (ardeid colonies in San Francisco Bay area in 2011); John Sterling (parts of the northern and central coast in 2011); Michelle Gilbert, Cory Gregory, and Khara Strum (Central Valley in 2011 or 2012); and Kim Oldehoeft (Los Angeles and Orange counties), Julie Szabo (Riverside Co.), Matt Whitmire (Los Angeles Co.), and Francesca Zern (San Diego Co.), all in 2012. The following individuals kindly shared data from colonies on military bases in California: Kirsten Christopherson (Beale Air Force Base), Francesca Ferrara (Naval Base Ventura County), Bob Schallmann (Naval Weapons Station Seal Beach), Barak Shemai (Marine Corps Base Camp Pendleton), and Tiffany M. Shepherd and Andrew Wastell (various naval installations around San Diego Bay).

Because of California's large size and the inaccessibility of many colonies from the ground or water, aerial surveys were essential for searching far and wide for the many colonies we otherwise would have missed. California Department of Fish and Wildlife (CDFW) biologists Esther Burkett and, particularly, Lyann Comrack arranged for plane time and coordinated flights with individual pilots and Ron VanBenthuysen, senior pilot with CDFW's Air Services Unit in Sacramento. Many thanks to CDFW's highly skilled pilots: Michael Breiling, Tom Evans, Gary Schales, Jeff Veal, and Gavin Woelfel. Shuford was accompanied on one or more of these flights by biologists Justin Boster, Rob Doster, Michelle Gilbert, David Haines, Dave Mauser, Kristie Nelson, John Sterling, and Khara Strum. John Beckstrand and Dave Mauser also contributed data on ardeids from their flights for other species. Tom Anderson, Sonny Bono Salton Sea NWR, provided airboat support for surveys at the Salton Sea. Brian Accord kindly shared data on historical colonies from the California Natural Diversity Database, and Greg Golet provided locations of colonies visible on The Nature Conservancy's aerial images of riparian areas in the Sacramento Valley; we used both to focus our searches from both the air and ground.

The scope of the survey effort was greatly expanded by in-kind contributions from collaborating agencies and nonprofit organizations, including Audubon California, Audubon Canyon Ranch, CDFW, Los Angeles Department of Water and Power, Natural History Museum of Los Angeles County, other projects and divisions of Point Blue Conservation Science, San Francisco Bay Bird Observatory, The Nature Conservancy, and U.S. Fish and Wildlife Service (particularly the Klamath 
Basin, Sacramento, and San Luis NWR complexes and the Migratory Birds office of Region 8 in Sacramento).

Crucial administrative, logistical, and funding support was provided or facilitated by Bob Altman, Lance Benner, Esther Burkett, Paul Buttner, Neil Clipperton, Lyann Comrack, Rob Doster, Catherine Hickey, Rob Holbrook, Bob Shaffer, Dale Steele, Marie Strassburger, and Bruce Wilcox. We especially thank Lyann Comrack and Rob Doster for their unwavering support and encouragement of this project, which ensured its success. The manuscript was substantially improved by comments from Robert H. Doster, Robert E. Gill Jr., John Neill, and Philip Unitt.

Funding for this work was provided by the CDFW (Wildlife Branch-Nongame Wildlife Program), California Rice Commission, Imperial Irrigation District, Pasadena Audubon Society, S. D. Bechtel, Jr. Foundation, U.S. Fish and Wildlife Service's Migratory Bird Program (Region 8) and State Wildlife Grant F10AF00647 to CDFW, and individual contributions to Point Blue Conservation Science. ArcGIS software was generously provided through ESRI's program for nonprofit organizations. This is Point Blue contribution 2273.

\section{LITERATURE CITED}

Adkins, J. Y., Roby, D. D., Lyons, D. E., Courtot, K. N., Collis, K., Carter, H. R., Shuford, W. D., and Capitolo, P. J. 2014. Recent population size, trends, and limiting factors for the Double-crested Cormorant in western North America. J. Wildl. Mgmt. 78:1131-1142; doi.org/10.1002/jwmg.737.

Belluomini, L. A. 1978. Statewide heron rookery inventory. Nongame Wildl. Investigations Rep., Proj. W-54-R-10, Job IV-1, Calif. Dept. Fish Game, Sacramento (available from Calif. Dept. Fish Wildl., P.O. Box 944209, Sacramento, CA 94244-2090).

Bystrak, D. 1981. The North American Breeding Bird Survey. Studies Avian Biol. 6:34-41.

Carter, H. R., McChesney, G. J., Jaques, D. L., Strong, C. S., Parker, M. W., Takekawa, J. E., Jory, D. L., and Whitworth, D. L. 1992. Breeding populations of seabirds in California, 1989-1991, vols. 1 and 2. Report to U.S. Fish Wildl. Serv., Dixon, CA; https://farallones.noaa.gov/eco/seabird/pdf/news/journal/monitoringandstatus.pdf.

Cavitt, J. F., Jones, S. L., Wilson, N. M., Dieni, J. S., Zimmerman, T. S., Doster, R. H., and Howe, W. H. 2014. Atlas of breeding colonial waterbirds in the interior western United States. Res. Rep., U.S. Fish Wildl. Serv., Denver; www.fws.gov/ mountain-prairie/migbirds/species/birds/western_colonial/.

Doster, R. H., and Shuford, W. D. 2018. Recent trends in population size and distribution of Ring-billed and California gulls in the western United States, in Trends and traditions: Avifaunal change in western North America (W. D. Shuford, R. E. Gill Jr., and C. M. Handel, eds.), pp. 161-179. Studies of Western Birds 3. W. Field Ornithol., Camarillo, CA; doi.org/10.21199/SWB3.8.

Dunn, J. L., and Alderfer, J. 2017. Field Guide to the Birds of North America, 7th ed. Natl. Geogr., Washington, DC.

Fleskes, J. P. 2012. Wetlands of the Central Valley of California and Klamath Basin, in Wetland Habitats of North America: Ecology and Conservation Concerns (D. Batzer and A. Baldwin, eds.), pp. 357-370. Univ. of Calif. Press, Berkeley.

Fleskes, J. P., Casazza, M. L., Overton, C. T., Matchett, E. L., and Yee, J. L. 2018. Changes in the abundance and distribution of waterfowl wintering in the Central Valley of California, 1973-2000, in Trends and traditions: Avifaunal change in western North America (W. D. Shuford, R. E. Gill Jr., and C. M. Handel, eds.), pp. 50-74. Studies of Western Birds 3. W. Field Ornithol., Camarillo, CA; doi. org/10.21199/SWB3.2. 
Frayer, W. E., Peters, D. D., and Pywell, H. R. 1989. Wetlands of the California Central Valley: Status and trends. Report of U.S. Fish Wildl. Serv., Portland, OR; catalog. hathitrust.org/Record/102513976.

Grinnell, J., and Miller, A. H. 1944. The distribution of the birds of California. Pac. Coast Avifauna 27.

Hickman, J. C. (ed.). 1993. The Jepson Manual: Higher Plants of California. Univ. of Calif. Press, Berkeley.

Hothem, R. L., Brussee, B. E., and Davis, W. E., Jr. 2010. Black-crowned NightHeron (Nycticorax nycticorax), in The Birds of North America Online (A. F. Poole, ed.), no. 74. Cornell Lab Ornithol., Ithaca, NY; doi.org/10.2173/bna.74.

Hurlbert, A. H., Anderson, T. W., Sturm, K. K., and Hurlbert, S. H. 2007. Fish and fish-eating birds at the Salton Sea: A century of boom and bust. Lake Reservoir Mgmt. 23:469-499; doi.org/10.1080/07438140709354033.

Jones, S. L. 2008. Western Colonial Waterbird Survey protocols. Report of U.S. Fish and Wild. Serv., Nongame Migratory Birds Coordinator's Office, Denver; www. fws.gov/mountain-prairie/migbirds/species/birds/western_colonial/.

Kelly, J. P., and Condeso, T. E. 2014. Rainfall effects on heron and egret nest abundance in the San Francisco Bay area. Wetlands 34:893-903; doi.org/10.1007/ s13157-014-0551-0.

Kelly, J. P., and Robinson-Nilsen, C. 2011. Tidal marsh herons and egrets, in The State of the Birds, San Francisco Bay (M. Pitkin and J. Wood, eds.), pp. 14-15. PRBO Conservation Science and the San Francisco Bay Joint Venture; www. egret.org/sites/default/files/kelly_robinson-nilsen_2011_stateofthebirds_0.pdf.

Kelly, J. P., Etienne, K., Strong, C., McCaustland, M., and Parkes, M. 2006. Annotated atlas and implications for the conservation of heron and egret nesting colonies in the San Francisco Bay area. ACR Tech. Rep. 90-3-17; www.egret.org/atlas.

Kelly, J. P., Etienne, K., Strong, C., McCaustland, M., and Parkes, M. L. 2007. Status, trends, and implications for the conservation of heron and egret nesting colonies in the San Francisco Bay area. Waterbirds 30:455-478.

Kelly, J. P., Millus, S. A., and Condeso, T. E. 2018. Nesting dynamics of four ardeid species at subregional scales: Recovery rates after sudden major declines in nest abundance. Waterbirds 41:223-237; doi.org/10.1675/063.041.0302.

Kushlan, J. A., Steinkamp, M. J., Parsons, K. C., et 20 al. 2002. Waterbird conservation for the Americas: The North American Waterbird Conservation Plan, version 1. Waterbird Conservation for the Americas, Washington, DC; www.fws.gov/migratorybirds/pdf/management/northamericawaterbirdconservationplan.pdf.

Lehman, P. E. 2019. The Birds of Santa Barbara County, California, rev. ed.; www. sbcobirding.com/lehmanbosbc.html.

Molina, K. C., and Shuford, W. D. 2013. Surveys of colonial nesting waterbirds at the Salton Sea in 2012. Report to the Imperial Irrigation District, P.O. Box 937, Imperial, CA 92251.

Molina, K. C., and Sturm, K. K. 2004. Annual colony site occupation and patterns of abundance of breeding cormorant, herons, and ibis at the Salton Sea. Studies Avian Biol. 27:42-51.

Ogden, L. E. 2013. Drone ecology. BioScience 63:776-776.

Pacific Flyway Council. 2013. A monitoring strategy for the western population of Double-crested Cormorants within the Pacific Flyway. Pacific Flyway Council, U.S. Fish Wildl. Serv., Portland, OR; pacificflyway.gov/Documents/Dcc_monitoring.pdf.

Pacific Flyway Council. 2018. A monitoring strategy for the western population of American White Pelicans: 2018 revision. Pacific Flyway Council, U.S. Fish Wildl. Serv., Portland, OR; pacificflyway.gov/Documents/Awp_monitoring.pdf.

Pandolfino, E. R., and Handel, C. M. 2018. Population trends of birds wintering in the Central Valley of California, in Trends and traditions: Avifaunal change in 


\section{DISTRIBUTION OF CALIFORNIA HERON AND EGRET COLONIES}

western North America (W. D. Shuford, R. E. Gill Jr., and C. M. Handel, eds.), pp. 215-235. Studies of Western Birds 3. W. Field Ornithol., Camarillo, CA; doi.org/10.21199/SWB3.12.

Patten, M. A., McCaskie, G., and Unitt, P. 2003. Birds of the Salton Sea: Status, Biogeography, and Ecology. Univ. of Calif. Press, Berkeley.

Pratt, H. M. 1983. Marin County California heron colonies: 1967-1981. W. Birds 14:169-184.

Pratt, H. M., and Winkler, D. W. 1985. Clutch size, timing of laying, and reproductive success in a colony of Great Blue Herons and Great Egrets. Auk 102:49-63.

Robbins, C. S., Bystrak, D., and Geissler, P. H. 1986. The Breeding Bird Survey: Its first fifteen years, 1965-1979. Resource Publ. 157, U.S. Fish Wildl. Serv., Washington, DC.

Sauer, J. R., Hines, J. E., Fallon, J. E., Pardieck, K. L., Ziolkowski, D. J., Jr., and Link, W. A. 2014. The North American Breeding Bird Survey, results and analysis 1966-2012, version 02.19.2014. U.S. Geol. Surv. Patuxent Wildl. Res. Center, Laurel, MD; www.mbr-pwrc.usgs.gov/bbs/bbs2012.shtml.

Schlorff, R. W. 1982. Heronry inventory. Nongame Wildl. Investigations Rep., Proj. W-54-R-14, Job III-8, Calif. Dept. Fish Game, Sacramento; nrm.dfg.ca.gov/ FileHandler.ashx? DocumentID $=40685$.

Seavy, N. E., and Reynolds, M. H. 2009. Seabird nest counts: A test of monitoring metrics using Red-tailed Tropicbirds. J. Field Ornithol. 80:297-302.

Seto, N. W. H. 2008. Coordinated colonial waterbird inventory and monitoring in the western United States: Comprehensive breeding season surveys. U.S. Fish Wildl. Serv., Migratory Birds and Habitat Programs, Portland, OR; www.fws. gov/mountain-prairie/migbirds/species/birds/western_colonial/.

Shuford, W. D. 2010. Inland-breeding pelicans, cormorants, gulls, and terns in California: A catalogue, digital atlas, and conservation tool. Wildl. Branch, Nongame Wildl. Program Rep. 2010-01. Calif. Dept. Fish Game, Sacramento; nrm.dfg.ca.gov/FileHandler.ashx?DocumentID=24095 [minus digital atlas].

Shuford, W. D. 2014a. Patterns of distribution and abundance of breeding colonial waterbirds in the interior of California, 2009-2012. Report to Calif. Dept. Fish Wildl. and U.S. Fish Wildl. Serv. (Region 8); www.fws.gov/mountain-prairie/ migbirds/species/birds/western_colonial/.

Shuford, W. D. 2014b. Coastal California (BCR 32) Waterbird Conservation Plan: Encompassing the coastal slope and Coast Ranges of central and southern California and the Central Valley. A plan associated with the Waterbird Conservation for the Americas initiative; www.centralvalleyjointventure.org/assets/ pdf/BCR32_WaterbirdCon_interactive_10FEB14.pdf.

Shuford, W. D., and Dybala, K. E. 2017. Conservation objectives for wintering and breeding waterbirds in California's Central Valley. San Francisco Estuary Watershed Sci. 15(1): article 4; doi.org/10.15447/sfews.2017v15iss1art4.

Shuford, W. D., Page, G. W., and Kjelmyr, J. E. 1998. Patterns and dynamics of shorebird use of California's Central Valley. Condor 100:227-244; doi.org/10.2307/ 1370264.

Shuford, W. D., Warnock, N., Molina, K. C., and Black, A. E. 2000. Avifauna of the Salton Sea: Abundance, distribution, and annual phenology. Final report for EPA contract R826552-01-0 to the Salton Sea Authority, 78401 Highway 111, La Quinta, CA 92253.

Shuford, W. D., Thompson, D. L., Mauser, D. M., and Beckstrand, J. 2006. Abundance and distribution of nongame waterbirds in the Klamath Basin of Oregon and California from comprehensive surveys in 2003 to 2004. Final report to U.S. Fish Wildl. Serv., Klamath Basin Natl. Wildl. Refuge Complex, 4009 Hill Rd., Tulelake, CA 96134.

Shuford, W. D., Humphrey, J. M., Hansen, R. B., Page, G. W., Stenzel, L. E., and 


\section{DISTRIBUTION OF CALIFORNIA HERON AND EGRET COLONIES}

Hickey. C. M. 2007. Summer distribution, abundance, and habitat use of Black-necked Stilts and American Avocets in California's Central Valley. W. Birds 38:11-28.

Shuford, W. D., Sesser, K. A., Strum, K. M., Haines, D. B., and Skalos, D. A. 2016. Numbers of terns breeding inland in California: Trends or tribulations? W. Birds 47:182-213; doi.org/10.21199/WB47.3.1.

Steinkamp, M., Peterjohn, B., Byrd, V., Carter, H., and Lowe, R. 2003. Breeding season survey techniques for seabirds and colonial waterbirds throughout North America. Draft 13 February 2003; www.bu.edu/scscb/working_groups/ resources/steinkamp-survey-techniques.pdf.

Swain, D. L. 2015. A tale of two California droughts: Lessons amidst record warmth and dryness in a region of complex physical and human geography. Geophys. Res. Lett. 42:9999-10,003; doi.org/10.1002/2015GL066628.

Swain, D. L., Langenbrunner, B., Neelin, J. D., and Hall, A. 2018. Increasing precipitation volatility in twenty-first century California. Nat. Clim. Change 8:427-433; doi.org/10.1038/s41558-018-0140-y.

Unitt, P. 2004. San Diego County bird atlas. Proc. San Diego Soc. Nat. Hist. 39.

Velasco, C. A. 2013. From rural to urban: The creation of water markets, agriculture and farmworkers in California's Imperial Valley. M. S. thesis, Columbia Univ., New York; doi.org/10.7916/D88K7H7C.

Wang, S.-Y. S., Yoon, J.-H., Becker, E., and Gillies, R. 2017. California from drought to deluge. Nat. Clim. Change 7:465-468; doi.org/10.1038/nclimate3330.

Williams A. P., Cook, E. R., Smerdon, J. E., Cook, B. I., Abatzoglou, J. T., Bolles, K., Baek, S. H., Badger, A. M., and Livneh, B. 2020. Large contribution from anthropogenic warming to an emerging North American megadrought. Science 368:314-318; doi.org/10.1126/science.aaz9600.

Accepted 9 March 2020 


\section{CHANGES IN THE STATUS AND DISTRIBUTION OF THE CINEREOUS AND FULVOUS OWLS IN MEXICO}

NATHAN PIEPLOW, 317 UCB, University of Colorado, Boulder, Colorado 80309; npieplow@gmail.com

ANDREW SPENCER, 562 Ellis Hollow Creek Rd., Ithaca, New York 14850

CARLOS SANCHEZ, 8305 SW 152nd Ave., Apt. 312, Miami, Florida 33193

MANUEL GROSSELET, Colina 145, Lomas de Bezares, Miguel Hidalgo, C.P. 11910, Ciudad de México, D.F., Mexico

ABSTRACT: Once widespread and apparently common in the mountains of mainland Mexico, to which it is endemic, the Cinereous Owl (Strix sartorii) seems to have declined precipitously. In 2015, 2016, 2017, and 2019 we searched for the Cinereous Owl in eight Mexican states where it had been reported previously. We detected it at only a single site, Rancho La Noria on Cerro San Juan, Nayarit. Our results suggest that the Cinereous Owl may have disappeared from much of its former range, and that the Fulvous Owl (Strix fulvescens) may now inhabit areas in Oaxaca formerly occupied by the Cinereous Owl, perhaps as a result of habitat alteration. The Cinereous Owl may qualify for recognition as vulnerable or endangered. Comprehensive surveys are urgently needed to establish its current status and distribution. Such surveys should also be used to determine the current distribution of the Fulvous Owl, and to investigate the reasons why it now occurs in areas formerly occupied by the Cinereous Owl.

Specimens of the Cinereous Owl (Strix sartorii) have been taken in at least nine Mexican states, as far south as Oaxaca and as far north as Durango and San Luis Potosí (Figure 1). The known specimen locations are widely scattered throughout the Sierra Madre Occidental and the Sierra Madre Oriental, at elevations ranging from as low as 600 meters to as high as 3000 meters.

The habitat of the bird appears to be montane pine and pine-oak forests. Ridgway (Baird and Ridgway 1873) reported that the type specimen was taken in the "pine region" of Hacienda Mirador, Veracruz (Figure 1M). Cox (1895) reported seeing a Cinereous Owl "in the deep pine forests about halfway up Peak Orizaba," but being unable to collect it. Binford (1989) described the habitat at the Oaxaca specimen locations as "high elevation humid pine-oak forest." The habitat on Cerro San Juan in Nayarit (Figure 1B), one of only two locations where the species has been recorded since 2015, is relatively humid pine-oak forest at about 1650 meters.

During the late $19^{\text {th }}$ and early $20^{\text {th }}$ centuries, the Cinereous Owl was widespread and, in the judgment of Salvin and Godman (1879), "apparently not uncommon in western Mexico.” Steve N. G. Howell (pers. comm.) reported to us that Charles Sibley had once told him of hearing Cinereous Owls "frequently" in Nayarit and Jalisco during his field work on towhee hybridization in the late 1940s and early 1950s.

By the second half of the $20^{\text {th }}$ century, the Cinereous Owl had apparently declined precipitously. A 1983 specimen from Guerrero (Universidad Autónoma de México Museum of Zoology 3581) is the only one taken after 1950. Binford (1989) listed the species as "rare" in Oaxaca, unrecorded there except for three specimens taken in 1857 and 1894. As recently as 2015, no 


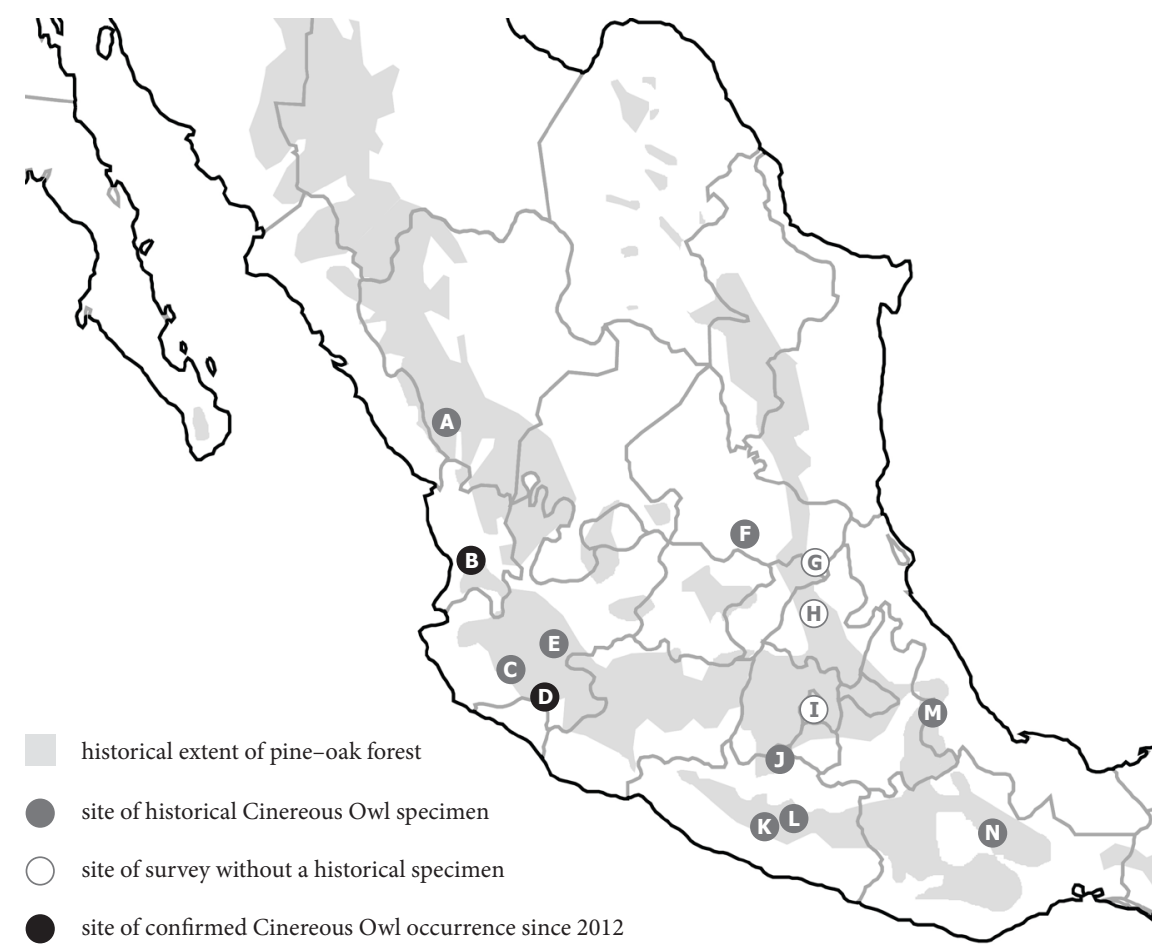

FIgURE 1. Locations of specimens of and surveys for the Cinereous and Fulvous Owls. A, La Ciudad, Durango; B, Cerro San Juan, Nayarit; C, Autlán, Jalisco; D, Parque Nacional Nevado de Colima, Jalisco; E, Cerro Viejo, Jalisco; F, Cerro Lucero, San Luis Potosí; G, La Trinidad, San Luis Potosí; H, Tlanchinol, Hidalgo; I, Parque Nacional Desierto de Leones, Ciudad de México; J, Coapango, Guerrero; K, Cerro Tiotepec, Guerrero; L, Parque Ecológico Estatal Omiltemi, Guerrero; M, Hacienda Mirador, Veracruz; N. Cerro San Felipe, Oaxaca.

photographs of sartorii had been published, and its voice remained undescribed. Strix sartorii has usually been considered a subspecies of S. varia, the Barred Owl, as by the American Ornithologists' Union (1998). Pieplow and Spencer (2020) summarized the evidence that it should be considered a separate species.

\section{METHODS}

In 2016, 2017, and 2019, we searched extensively for the Cinereous Owl throughout its historic range in Mexico. We prioritized areas with historical specimen records.

We know of 35 specimens of the Cinereous Owl collected at 19 named sites. Using specimen metadata, published sources, and maps, we established the locations of nine of these sites with a high degree of certainty (within 
roughly $5 \mathrm{~km}$ ). We located an additional seven sites with a moderate degree of uncertainty $(5-50 \mathrm{~km})$. But three of the 19 locations are uncertain. Two are specific only to state (Michoacán and Guerrero). The third specimen (Natural History Museum of the United Kingdom 1888.7.20.225) is labeled as "Ciudad Durango." This locality is often assumed to refer to the city of Durango, which sits in the open desert of the Mexican Plateau, far from the nearest habitat for the Cinereous Owl. However, we consider it more likely that this specimen is from the town known as "La Ciudad" in the state of Durango (Figure 1A), which lies at $23.73^{\circ} \mathrm{N}, 105.69^{\circ} \mathrm{W}$, about $110 \mathrm{~km}$ west-southwest of the city of Durango, and is surrounded by pine forest.

The 17 historical sites that can be located with at least moderate certainty cluster into 9 geographic areas, each consisting of sites within the same mountain range and likely within the same block of historically continuous habitat. The cluster of records in Nayarit since 2015 constitutes an additional area.

In June 2016, January 2017, and March 2019, we carried out informal surveys for the Cinereous Owl in six of the nine historically inhabited areas. The remaining three areas we did not visit because of security concerns. We also surveyed a few additional areas where we considered it possible that the species might occur.

All surveys were along roads and consisted of listening for a few minutes, then playing recordings of the rhythmic song and the series song of a Cinereous Owl recorded in Nayarit, then listening for a few more minutes. Surveys in Oaxaca also included broadcast of rhythmic song of the Fulvous Owl (Strix fulvescens). See Pieplow and Spencer (2020) for spectrograms and discussion of these calls.

We did not standardize the number of minutes spent listening, the number or order of songs broadcast, or the distance between survey points. On average, trials lasted about 10 minutes. Surveys consisted of 2-12 trials at points at least 250 meters apart. Surveys either began 30 minutes after sunset or concluded 30 minutes before sunrise. In 2016 we conducted approximately 41 trials across 9 sites, in 2017 we conducted 48 trials across 6 sites, and in 2019 we conducted 23 trials across 4 sites.

\section{RESULTS}

Our surveys in 2016, 2017, and 2019 did not detect any Cinereous Owls.

In the area of Tlanchinol, Hidalgo (Figure $1 \mathrm{H}$ ), we surveyed along the Huazalingo road on the evening of 3 June 2016 and on the Lontla track on the morning of 4 June 2016. The habitat at both sites was good-quality cloud forest with little, if any, pine. We surveyed at La Trinidad, San Luis Potosí (Figure 1G), on the evening of 4 June 2016 and the morning and evening of 5 June 2016. The habitat here was good-quality cloud forest grading into humid pine-oak forest. We had no particular expectation of finding Cinereous Owls in cloud forest, a habitat from which they are unreported, but as this habitat is (or once was) widespread in areas between locations of specimens in the Sierra Madre Oriental, we considered it possible that it might support the species locally.

On the evening of 6 June and the morning of 7 June 2016, we surveyed Cerro Lucero, San Luis Potosí (Figure 1F). We believe that our survey included 
the exact location where Robert J. Newman collected two Cinereous Owls in 1950. The area is privately owned, and we obtained permission for our surveys from the inhabitants of the nearby farmhouse. Although the canopy of the pine-oak forest remained nearly continuous in places, logging had removed all pines of large diameter, and grazing had removed nearly all understory.

On the evening of 9 June and the morning of 10 June 2016, we surveyed the lower elevations of the Parque Nacional Nevado de Colima in Jalisco (Figure 1D), from the park boundary to the start of the zone of oyamel fir (Abies religiosa). This stretch of road passes through high-quality pine-oak forest with many tall and robust pines.

On the morning of 17 June 2016, broadcasting songs of both species, we surveyed for the Cinereous and Fulvous Owls at km 119 and km 148 along Highway 175 between Oaxaca and Tuxtepec in the state of Oaxaca (Figure $1 \mathrm{~N})$, in areas of fairly tall, dry pine-oak forest that had been grazed fairly clean of understory. We detected three Fulvous Owls at km $119\left(17.52^{\circ} \mathrm{N}\right.$, $96.51^{\circ} \mathrm{W}$ ), including a pair that responded vigorously to playback, permitting good recordings and photographs (https://ebird.org/checklist/S30307453).

On the morning of 18 June 2016, we surveyed the rather sparse pine-oak forest below the settlement of Benito Juárez, above Teotitlán del Valle, Oaxaca. On the morning of 19 June 2016, we surveyed the Villa Alta road just outside Totontepec, Oaxaca. This area contained good-quality cloud forest with only a few pines. We detected one Fulvous Owl. On the morning of 20 June 2016, we surveyed Cerro San Felipe in Oaxaca. This area contains good-quality pine-oak forest, including some tall and massive pines. We detected one Fulvous Owl.

On the evening of 6 January and the morning of 7 January 2017 we returned to survey the Parque Nacional Nevado de Colima in Jalisco. On the evening of 7 January we surveyed the lower portions of the Volcán de Fuego road that heads west from Mexico Highway 54D just south of Atenquique, Jalisco. Road conditions and the closure of the upper portion of the route by volcano activity prevented us from reaching an elevation with many pine trees.

On the morning of 8 January 2017 we surveyed the lower portions of the Radio Microondas Víboras road on the northwest flank of Nevado de Colima, Jalisco. The area contained good-quality pine-oak forest, including tall and large-diameter pines. On the evening of 8 January 2017 we surveyed the Puerto Los Mazos microwave tower road above Autlán, Jalisco (Figure 1C). The area was too low and dry to support many pine trees.

On the evening of 9 January 2017 we surveyed Cerro Viejo, $22 \mathrm{~km}$ southwest of Guadalajara, Jalisco (Figure 1E). The area is owned by the Ejido San Miguel Cuyutlán, and we obtained permission to enter for our surveys. (An ejido is a communal land grant awarded to farmers by the Mexican government.) The forest had been extensively logged; the remaining trees were almost exclusively oaks.

On the morning of 11 January 2017 we surveyed the Parque Nacional Desierto de Leones in Mexico City (Figure 1I). The area included some pine-oak forest with tall pines.

On the evening of 26 March 2019 we surveyed along the road to La Pintada, off Mexico Highway 196 above El Paraíso, Guerrero. The habitat was cloud forest with only a few pines. On the morning and evening of $27 \mathrm{March}$ 2019, we surveyed along Mexico Highway 196 from about $5 \mathrm{~km}$ below Puerto 
El Gallo to about $5 \mathrm{~km}$ above it, on the south flank of Cerro Tiotepec, to within about $5 \mathrm{~km}$ of the peak (Figure $1 \mathrm{~K}$ ). Local residents advised us not to continue farther up the road at night because of security concerns. The area contained good quality pine-oak forest, including some tall and massive pines. The area of the peak itself, which we visited only in daylight, contained good-quality coniferous forest with a large number of oyamel firs.

On the evening of 29 March 2019 we surveyed the area above Azinyahualco, Guerrero (Figure 1L), on land owned by the local Ejido Azinyahualco, with permission. The area was steep and rocky, covered primarily by low brush, with only a few scattered pine trees. We did not survey at the nearby location of Omiltemi on the advice of local residents who cited security concerns. However, J. L. Mena (pers. comm.) visited the Omiltemi area in daylight in 2013. He reported that the site has been severely degraded by logging, with large areas being completely cleared for the raising of livestock and cultivation of the opium poppy, and that pine trees remain in only a few isolated stands.

\section{DISCUSSION}

\section{Apparent Range Expansion by the Fulvous Owl}

The Fulvous Owl occurs from Honduras to southern Mexico; its habitat is montane pine forest and cloud forest (e.g., Dickey and van Rossem 1938, Gómez de Silva et al. 1999). Prior to 2009, most researchers considered the Cinereous and Fulvous Owls allopatric, their ranges separated by the low-lying Isthmus of Tehuantepec. For many years, the only evidence of the Fulvous Owl northwest of the isthmus consisted of four specimens supposedly taken at Totontepec, Oaxaca, in 1942 by Mario del Toro Avilés. These specimens (now in the Moore Laboratory of Zoology, Occidental College, Los Angeles) have long been controversial, in part because no other evidence was available to support an extension of the Fulvous Owl's range across the isthmus. Several authors (e.g., Binford 1989) cited examples of apparently incorrect locations on labels of other specimens collected by del Toro Avilés to cast doubt on his Totontepec Fulvous Owl specimens.

Since 2009, however, multiple photographs and audio recordings have conclusively established the occurrence of the Fulvous Owl at several locations in the Sierra Madre de Oaxaca north of Oaxaca City (Ramírez-Julián et al. 2011, eBird.org, xeno-canto.org). These locations include Cerro San Felipe (Figure 1N), which includes or sits adjacent to the locations of the $19^{\text {th }}$ century specimens of the Cinereous Owl.

In 2016 we recorded a Fulvous Owl at Totontepec (ML 171293391), the site of del Toro Avilés' controversial specimens. All the other specimens that del Toro Avilés labeled "Totontepec" are of species expected at that location (J. Maley pers. comm.). Thus we believe it likely that del Toro Avilés' Fulvous Owl specimens were indeed procured at that site, implying that Fulvous Owls have occurred in Oaxaca at least since 1942.

Meanwhile, the Cinereous Owl remains unrecorded in Oaxaca since 1894. It appears that the Fulvous Owl is now occupying areas in Oaxaca where the Cinereous Owl used to occur. The reasons for the apparent change in distribution of both species remain unknown. 


\section{Status of the Cinereous Owl}

Our failure to detect the Cinereous Owl during our 2016, 2017, and 2019 surveys suggests that the species, once widespread and "not uncommon," is now rare and local, and may qualify for designation as vulnerable or endangered. Since 2015, the species continues to be detected regularly in the vicinity of Cerro San Juan, Nayarit (Figure 1B). However, we and other observers have failed to document it in recent decades at most sites in its historical range.

A comprehensive survey effort is urgently required to establish the extent and the causes of the Cinereous Owl's decline. Surveys are also needed to determine the extent and causes of the apparent expansion of the Fulvous Owl into areas formerly occupied by the Cinereous Owl. It is possible that habitat alteration such as the selective logging of the largest pine trees has proved detrimental to the Cinereous Owl and beneficial to the smaller Fulvous Owl, perhaps by reducing the average size of available nest sites.

If the Cinereous and Fulvous Owls are in contact anywhere, it is possible that they interbreed or compete in those areas, as the Barred and Spotted Owls do in the northwestern United States (Gutiérrez et al. 2007). However, given the smaller size of the Fulvous Owl, it seems unlikely that it would displace its larger congener via direct competition (R. Gutiérrez pers. comm.). It is possible that the disappearance of the Cinereous Owl from Oaxaca has removed interspecific competition that might previously have prevented Fulvous Owls from occupying the area. If this is the case, the range expansion of the Fulvous Owl may actually provide additional evidence of decline of the Cinereous Owl (R. Gutiérrez pers. comm.).

Future surveyors should consider whether the relatively short duration of the listening periods in our surveys may have reduced the likelihood of our detecting a Cinereous Owl. Barred Owls (McGarigal and Fraser 1985) and Cinereous Owls (M. Stackhouse pers. comm.) frequently approach in response to broadcast of their songs silently, vocalizing only after many minutes, if at all. Broadcast of the Cinereous Owl's series song in preference over its rhythmic song might increase the likelihood of detection and reduce response time (M. Stackhouse pers. comm.). An optimal survey protocol might set points farther apart (up to $1 \mathrm{~km}$ ) but increase the number of points surveyed per transect and the number of transects completed per night ( $R$. Gutiérrez pers. comm.).

It is also possible that the maximum elevation of our surveys was too low. After completing our surveys, we were able to view Fernando Romo's photographs from 6 October 2012 of a Cinereous Owl on Nevado de Colima, Jalisco (Figure 1D), at an altitude of 3800 meters, well above the transition into oyamel fir forest, and above the highest altitude of our surveys. This record suggests that Cinereous Owls should also be sought at higher elevations in forest of oyamel fir.

\section{ACKNOWLEDGMENTS}

We thank Alberto Martínez, José Luis Mena, and Bob McGuire for accompanying us on surveys in the field. Steve N. G. Howell was instrumental in our successful 2015 effort to document the Cinereous Owl in Nayarit. We also thank Ned Brinkley, 
Leonardo Chapa Vargas, Víctor L. Güitrón, Gerardo Hernández Vázquez, Dan Lane, Roberto Pedraza Ruiz, Michael Retter, Fernando Romo, Chris Sharpe, Mark Stackhouse, Ingrid Tello-López, and Bernardillo Villa Bonilla for helpful discussion about Strix owls and nocturnal survey sites in Mexico.

For access to museum specimens and other key information, we thank Carla Cicero, Florine Pascale, and Lelena Avila at the Museum of Vertebrate Zoology at the University of California, Berkeley; Paul R. Sweet and Lydia Garetano of the American Museum of Natural History; Van Remsen, Steve Cardiff, and Tammie Jackson at the Louisiana State University Museum of Natural Science; Mark Adams at the Natural History Museum in London; and James Maley and Jessie Salter at the Moore Laboratory of Zoology at Occidental College.

We thank George Barrowclough and R. J. Gutiérrez for their technical review of our manuscript.

\section{LITERATURE CITED}

American Ornithologists' Union. 1998. Check-list of North American Birds, $7^{\text {th }}$ ed. Am. Ornithol. Union, Washington, DC.

Baird, S. F., and Ridgway, R. 1873. On some new forms of American birds. Bull. Essex Inst. 5(12): 197-201.

Binford, L. C. 1989. A distributional survey of the birds of the Mexican state of Oaxaca. Ornithol. Monogr. 43; doi.org/10.2307/40167673.

Cox, U. O. 1895. A collection of birds from Mount Orizaba, Mexico. Auk 12:357; doi.org/10.2307/4068943.

Dickey, D. R., and van Rossem, A. J. 1938. The birds of El Salvador. Field Mus. Nat. Hist. Zool. Ser 23.

Gómez de Silva G., H., González-García, F., and Casillas-Trejo, M. P. 1999. Birds of the upper cloud forest of El Triunfo, Chiapas, Mexico. Ornitol. Neotrop. $10: 1-26$.

Gutiérrez, R. J., Cody, M., Courtney, S., and Franklin, A. B. 2007. The invasion of Barred Owls and its potential effect on the Spotted Owl: A conservation conundrum. Biol. Invasions 9:181-196; doi.org/10.1007/s10530-006-9025-5.

McGarigal, K., and Fraser, J. D. 1985. Barred Owl responses to recorded vocalizations. Condor 87:552-553; doi.org/10.2307/1367961.

Pieplow, N., and Spencer, A. 2020. Vocal differences among the Barred, Cinereous, and Fulvous Owls. W. Birds 51:122-128; doi.org/21199/WB51.2.5.

Ramírez-Julián, R., González-García, F., and Reyes-Macedo, G. 2011. Registro del búho leonado Strix fulvescens en el estado de Oaxaca, México. Rev. Mex. Biodivers. 82:727-730; doi.org/10.22201/ib.20078706e.2011.2.491.

Salvin, O., and Godman, R. D. 1879. Biologia Centrali-Americana. Aves, vol. III, part I. R. H. Porter, London. 


\section{THE $44^{\text {TH }}$ ANNUAL REPORT OF THE CALIFORNIA BIRD RECORDS COMMITTEE: 2018 RECORDS}

THOMAS A. BENSON, California State University San Bernardino, 5500 University Parkway, San Bernardino, California 92407; secretary@californiabirds.org

ROB FOWLER, 1386 Fernwood Drive, McKinleyville, California 95519;

migratoriusfwlr@gmail.com

GUY McCASKIE, 954 Grove Avenue, Imperial Beach, California 91932;

guymcc@pacbell.net

JUSTYN T. STAHL, 4177 Utah Street, San Diego, California 92104;

justyn.stahl@gmail.com

ABSTRACT: From its last report through 2018 the California Bird Records Committee reached decisions on 287 records involving 267 individuals of 79 species, two species groups, one hybrid, and two introduced populations, endorsing 250 records of 238 individuals and two introduced populations. The first accepted California records of the Eastern Meadowlark (Sturnella magna), the Tropical Parula (Setophaga pitiayumi), and the eastern group of subspecies of the Curve-billed Thrasher (Toxostoma curvirostre) are outlined in this report. The committee also voted to add naturalized populations of the Yellow-chevroned Parakeet (Brotogeris chiriri) and the Red-whiskered Bulbul (Pycnonotus jocosus) to the state list. These additions bring California's total list of accepted species to 675, of which 13 represent established introductions. Other notable records detailed in this report include the state's second Common Ringed Plover (Charadrius hiaticula), Marsh Sandpiper (Tringa stagnatilis), Gray Hawk (Buteo plagiatus), and Eurasian Skylark (Alauda arvensis), and third Wood Sandpiper (Tringa glareola), Tristram's Storm-Petrel (Hydrobates tristrami), and Red-flanked Bluetail (Tarsiger cyanurus).

This $44^{\text {th }}$ report of the California Bird Records Committee (CBRC), a committee of Western Field Ornithologists, summarizes evaluations of 287 records involving 267 individuals of 79 species, two species groups, one hybrid, and two introduced populations. The committee accepted 250 of the 287 records, involving 238 individuals of 66 species, two species groups, one hybrid, and two introduced populations for an acceptance rate of $87.1 \%$. A record is considered accepted if it receives no more than one "not accept" vote from the nine voting members if the identification is considered questionable, or no more than two "not accept" votes if the bird's natural occurrence is considered questionable. We consider 15 records of 11 individuals to represent returning or continuing birds. Thirty-six records, involving 37 individuals of 26 species and one species group, were not accepted because the identification was considered to be unsubstantiated; one record involving one individual was not accepted because its natural occurrence was questionable. For review, reports of multiple individuals together are given the same record number; we report the total number of accepted individuals, which may be different from the number of accepted records. Although most of the records in this report are of birds first documented in 2018, 24 are from prior years.

Since the period covered by this report, the committee has accepted the first California record of the Yellow-browed Warbler (Phylloscopus inornatus), the details of which will be published in the next $\left(45^{\text {th }}\right)$ report. This addition brings the California list to 676 species. At its January 2020 annual meeting, 
the committee added the Wood Stork (Mycteria americana) and removed the Nazca Booby (Sula granti), Red-footed Booby (Sula sula), and Rusty Blackbird (Euphagus carolinus) from the list of species that it reviews. As a result of the removal of the Nazca Booby, the category of Masked/Nazca Booby (Sula dactylatra/granti) was also removed from the review list.

Species-account headings are organized with English and scientific names first, followed in parentheses by the total number of individuals accepted for California (records in this report included) and the number of new individuals accepted in this report. Following the heading are accounts for records accepted (as applicable), followed by records not accepted because the identification was not established, the date or location was uncertain, or the natural occurrence was questionable (as applicable). A double asterisk $\left.{ }^{* *}\right)$ following the number of accepted records indicates that the species has been reviewed only during a restricted period, so the number of accepted records does not represent the total number of records for the state. When the observer(s) who originally discovered the bird provided documentation, their initials are listed first in italics, followed by the initials of subsequent observers supplying documentation. A dagger ( $\dagger$ ) following an observer's initials indicates submission of a photograph, (\$) indicates submission of a sketch, $(\$)$ indicates submission of audio recordings, ( $\ddagger)$ indicates submission of a video, and (\#) precedes a specimen number. We cite the following collections in this report: LACM, Natural History Museum of Los Angeles County; SDNHM, San Diego Natural History Museum; SOUNHM, Southern Oregon University Natural History Museum, Ashland. The absence of a symbol following the observer's initials indicates the submission of a written report without other documentation. After the observers' initials is the identifying number assigned by the CBRC's secretary as each record is received.

As of the CBRC's $43^{\text {rd }}$ report (Singer et al. 2020), age terminology follows that of Humphrey and Parkes (1959) as modified by Howell et al. (2003) and Howell and Pyle (2015). A document specifying terms for molts and ages is available at the CBRC's website, www.californiabirds.org/Age\%20and\%20 plumage\%20terminology.pdf. Definitions of abbreviations and additional details regarding minutiae of formatting may be found in the CBRC's previous annual reports (all available at www.californiabirds.org) and in Rare Birds of California (CBRC 2007; www.wfopublications.org/Rare_Birds/FM/ Explanation-Additional_Info.html). A map of, and abbreviations for, counties in California are at www.wfopublications.org/Rare_Birds/MAPS/Map1.html. Also available at the CBRC's website are the California bird list, the review list, an online form for submitting documentation for review species, committee news, recent photos of rare birds, the CBRC's bylaws, and a form for querying the CBRC's database. Observers are encouraged to submit documentation for all species on the CBRC's review list to the CBRC's secretary (e-mail: secretary@californiabirds.org) or via the web form at www.californiabirds. org/report_sighting.html. Documentation of all records is archived at the Western Foundation of Vertebrate Zoology (www.wfvz.org) and is available for public review by appointment or by contacting the CBRC's secretary.

FULVOUS WHISTLING-DUCK Dendrocygna bicolor $\left(8^{* *}, 2\right)$. One was at Lake Los Carneros and the Goleta Sanitary District plant, SBA, 9 Apr-7 Jul 2018 (RFC, $\mathrm{DMC}, \mathrm{NL}, \mathrm{BMo} \dagger, \mathrm{HPR} \dagger, \mathrm{CSp} \dagger$, JTS $\dagger, \mathrm{GTi}, \mathrm{TT} \dagger ; 2018-031$ ) and another (in formative 
plumage) was at the Ballona Freshwater Marsh, LA, 11-20 Jul 2018 (DSt†, DJB $\dagger$, $\mathrm{TAB} \dagger, \mathrm{CAD} \dagger, \mathrm{RE} \dagger, \mathrm{EL} \dagger, \mathrm{TGM} \uparrow \&, \mathrm{DSch} \dagger$, JTS $\dagger$, JCS $\dagger, \mathrm{CTa} \dagger, \mathrm{CLY} \dagger ; 2018-075)$. This duck bred along the coast of southern California until the early 1950s and in the Central Valley until 1983 (Hamilton 2008). In the Imperial Valley it persisted in declining numbers until 2010 but has not been confirmed as breeding since 1999 (N. Am. Birds 53:432), and the CBRC added it to the review list in 2011.

TRUMPETER SWAN Cygnus buccinator $\left(147^{\star *}, 0\right)$. IDENTIFICATION NOT ESTABLISHED: Two specimens at SOUNHM misidentified as Trumpeter Swans, one shot at Tule Lake, SIS, 16 Nov 1930 (SOUNHM \#582; 2007-045) and the other near Hilt, SIS, 27 Jan 1988 (SOUNHM \# 1675; 2007-046), are both Tundra Swans (C. columbianus). The committee reviews records of the Trumpeter Swan through 2011.

RUDDY SHELDUCK Tadorna ferruginea $(0,0)$. NATURAL OCCURRENCE QUESTIONABLE: One was near the Cosumnes River Preserve, SAC, 15 Oct 2018 (2018-192). This species is relatively common in captivity, and a natural vagrant to California is very unlikely.

BAIKAL TEAL Sibirionetta formosa $(8,1)$. A male in formative plumage was taken by a hunter $\sim 15 \mathrm{~km}$ southeast of Los Banos, MER, 12 Dec 2018 (DSco†; 2018-248).

KING EIDER Somateria spectabilis $(45,0)$. IDENTIFICATION NOT ESTABLISHED: Photos of a distant duck off the Sutro Baths in San Francisco, SF, 4 Jan 2018 (2018-008) were too poor to confirm the identification as a King Eider.

STEJNEGER'S SCOTER Melanitta stejnegeri $(0,0)$. IDENTIFICATION NOT ESTABLISHED: An adult male scoter photographed on Monterey Bay off Zils Road in Watsonville, SCZ, 15 Jan 2014 (2014-187; Figure 1) received some support as a Stejneger's Scoter, a potential first for California. Six committee members, however, were unwilling to endorse this identification, citing poor photos in which some field marks were difficult to interpret accurately. The American Ornithological Society recently split $M$. stejnegeri and $M$. deglandi from $M$. fusca (Chesser et al. 2019). The only record of Stejneger's Scoter in North America away from extreme western Alaska is of an adult male at Helena Valley Regulating Reservoir, Lewis and Clark County, Montana, 11 Apr-15 May 2015 (Jeff Marks pers. comm., Pyle et al. 2019).

RUDDY GROUND DOVE Columbina talpacoti $\left(117^{\star *}, 6\right)$. A female at Shoshone, INY, 19 Sep 2018 (JEP†; 2018-157) was only the third in California since January 2016. A flock of up to five with Inca Doves (C. inca) and Common Ground Doves (C. passerina) at the Palo Verde Ecological Reserve, RIV, 15 Dec 2018-20 Mar 2019 (CaS †; TAB $\dagger, \mathrm{LK} \dagger, \mathrm{DVP} \dagger ; 2018-224$ ) included three males, a female, and a bird in formative plumage. The committee reviews records of the Ruddy Ground Dove only prior to 2003 and since 2016.

BUFF-COLLARED NIGHTJAR Antrostomus ridgwayi $(1,0)$. IDENTIFICATION NOT ESTABLISHED: A report of one in Corona, RIV, 28 Mar 2018 (2018$029)$ lacked a description of the bird or its vocalizations and received no support.

RUBY-THROATED HUMMINGBIRD Archilochus colubris (20,1). A female on San Clemente Island, LA, 5 Sep 2014 (JTS $\dagger$; 2014-186) represented the first record for Los Angeles County. This individual had commenced preformative molt, which normally doesn't occur during migration.

BROAD-BILLED HUMMINGBIRD Cynanthus latirostris $(109,7)$. As in most cases with this rare stray to California, three reported in 2018 were frequenting feeders along the coast: single males in Bolinas, MRN, 2-6 Sep 2018 (KH†; MD LH†, ANW †; 2018-121), San Francisco, SF, 9-19 Mar 2018 (MWE $\dagger$, RFi, DK-B $\dagger$, DMo, DEQ $\dagger$, MJR $\dagger, \mathrm{RAR} \dagger, \mathrm{PS}, \mathrm{JCS} \dagger, \mathrm{SBT} ; 2018-028)$, and Mission Valley in San 
Diego, SD, 27 Feb 2018 (MMcC†; 2018-025). A female at Shoshone, INY, 1 May 2018 ( $L W \dagger ;$ 2018-067) and a male in Bishop, INY, 1-3 Oct 2018 (CHo†, RH†, NJO†; 2018-200) were frequenting feeders well inland in extreme eastern California, where the Broad-billed Hummingbird is recorded far less frequently than along the coast. A male of unknown age in Los Leones Canyon, LA, 26 Sep 2018 (KW†: 2018-161) and a male undergoing preformative molt at Grimes Point, MTY, 29 Sep 2018 (SO†; 2018-163) were attracted to wildflowers, and far from any feeders.

VIOLET-CROWNED HUMMINGBIRD Amazilia violiceps $(7,1)$. An adult visiting a feeder at the Kern River Preserve, KER, 7 Jul-2 Aug 2018 (JRS, TAB $\dagger$,

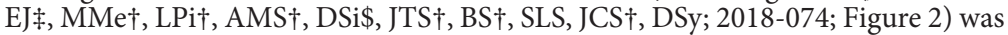
only the second to be found well inland in California; the other occurred at Grass Valley, NEV, on the unexpected date of 8 Feb 2006 (2006-030; Heindel and Garrett 2008). Five coastal records stretch from San Diego County to Humboldt County.

PURPLE GALLINULE Porphyrio martinicus $(6,1)$. Remains, consisting of one foot and one wing distal of the elbow, were recovered along Harbor Drive near the Tenth Avenue Marine Terminal on San Diego Bay, SD, 2 Nov 2018 (GN†; 2018-211) and deposited at the San Diego Natural History Museum (SDNHM \#56448).

EUROPEAN GOLDEN-PLOVER Pluvialis apricaria (0, 0). IDENTIFICATION NOT ESTABLISHED: A golden-plover photographed at Devereux Slough, SBA, 21-29 Jan 2017 (2017-176; Figure 3) received support from a majority of committee members during all four rounds of voting. Despite being reviewed and endorsed by several European experts as representing this species, the photos were slightly out of focus and did not show the diagnostic white underwing coverts, leaving three committee members unwilling to endorse what would have been the first record for California and second for the Pacific coast of North America.

COMMON RINGED PLOVER Charadrius hiaticula $(2,1)$. An adult male at Abbotts Lagoon, MRN, 8-15 Oct 2018 (MSaw†, LC†, DL†\$, AMa†, MJR†, JCS $\dagger$, GTe†; 2018-182) was the second Common Ringed Plover recorded in California. The photos, such as the one on this issue's front cover, show the prominent white supercilium and the lack of an orange orbital-ring that differentiate the Common Ringed from the very similar Semipalmated Plover (C. semipalmatus). The width of the black breast band indicates the bird is an adult male.

UPLAND SANDPIPER Bartramia longicauda $(34,2)$. One at Furnace Creek Ranch, INY, 27 May 2018 ( $A H \dagger$, DVP†, LST $\dagger$, SBT; 2018-048) was at a location where at least three have been found previously in late spring (CBRC 2007), and a juvenile was at Sacramento National Wildlife Refuge (NWR), GLE, 8 Sep 2018 $(W W \dagger ; 2018-131)$. IDENTIFICATION NOT ESTABLISHED: A report of an unseen, calling Upland Sandpiper at Elings Park in Santa Barbara, SBA, 21 Sep 2018 (2018154) was not endorsed by the committee.

BAR-TAILED GODWIT Limosa lapponica $(51,1)$. One was at Ocean Beach County Park, SBA, 11-12 Sep 2018 (BrH†, JEL, BKS †; 2018-142). Only 14 of California's 51 accepted records are from southern California.

HUDSONIAN GODWIT Limosa haemastica $(55,1)$. A juvenile at Kramer Junction, SBE, 17 Aug 2018 (TAB†; 2018-103) furnished the second record for San Bernardino County. Only 17 of California's 55 records come from the interior, with nine of those representing fall migrants.

CURLEW SANDPIPER Calidris ferruginea $(52,2)$. An adult female in alternate plumage was at Obsidian Butte, IMP, 3 May 2018 (JBe†; 2018-037). An adult molting into basic plumage was at the Tulare Lake Drainage District's Hacienda Basin, $28 \mathrm{~km}$ south-southwest of Corcoran, KIN, and the South Evaporation Ponds $7 \mathrm{~km}$ farther south, KER, 22 Jul-4 Aug 2018 (MES†, SLS †, SSu†; 2018-083). 


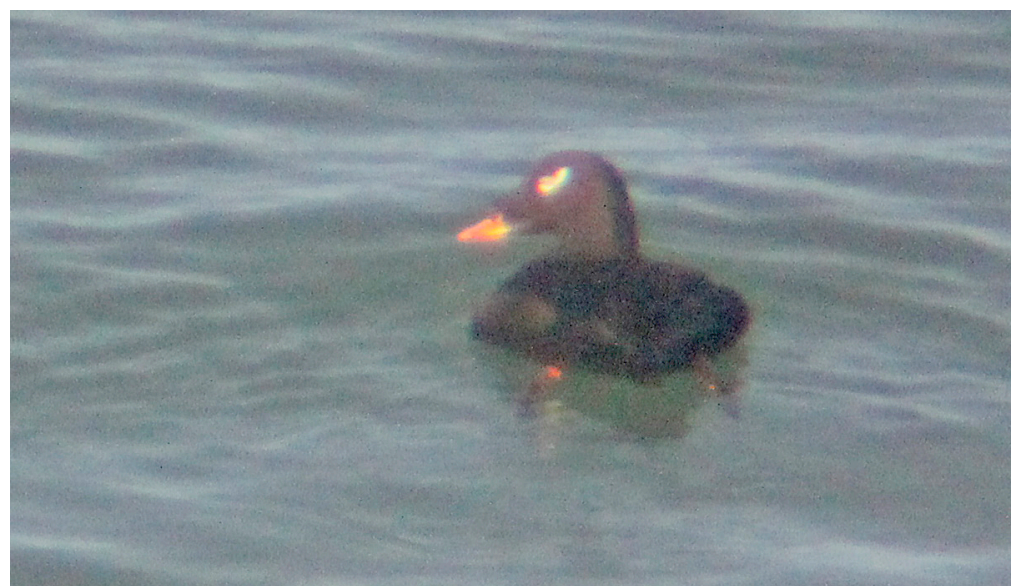

FIgURE 1. This adult male scoter, photographed from the end of Zils Road in Watsonville, Santa Cruz County, 15 Jan 2014 (2014-187), appears to show black flanks, a large protrusion at the base of the culmen, and a reddish-orange upper mandible with a yellow edge-features all consistent with Stejneger's Scoter. The majority of committee members, however, considered the photos insufficiently clear to establish a first state record.

Photo by John F. Garrett

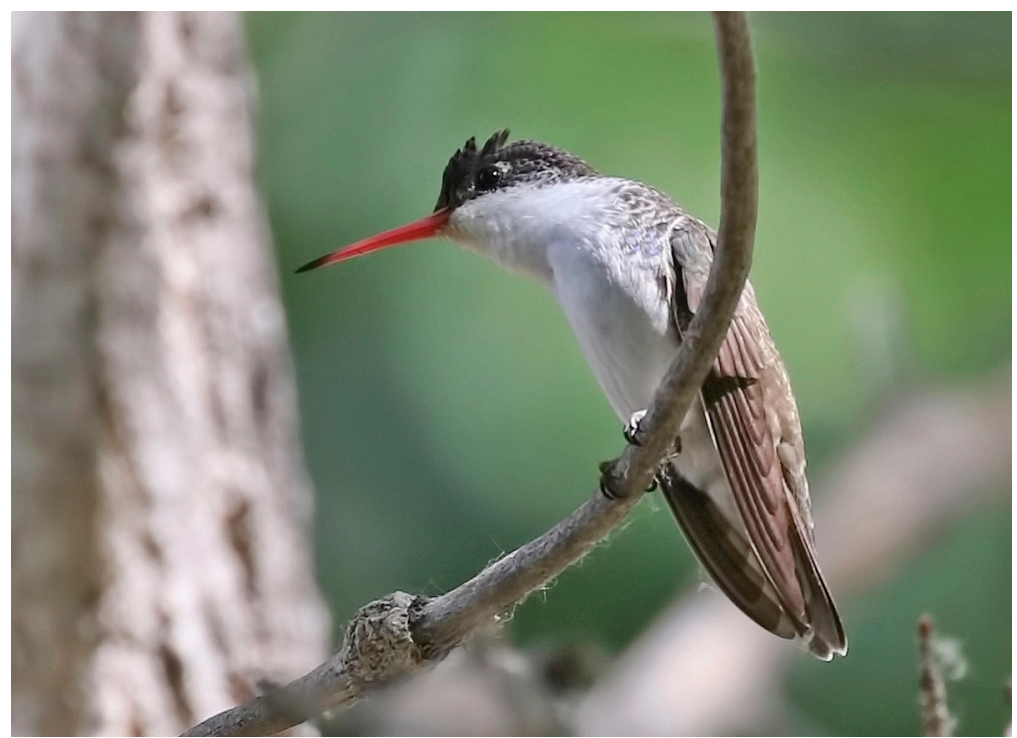

FIgURE 2. Showing its clean white underparts and mostly bright red bill, this adult Violet-crowned Hummingbird, photographed 9 Jul 2018, visited the hummingbird feeders at the Kern River Preserve, Kern County (2018-074). 


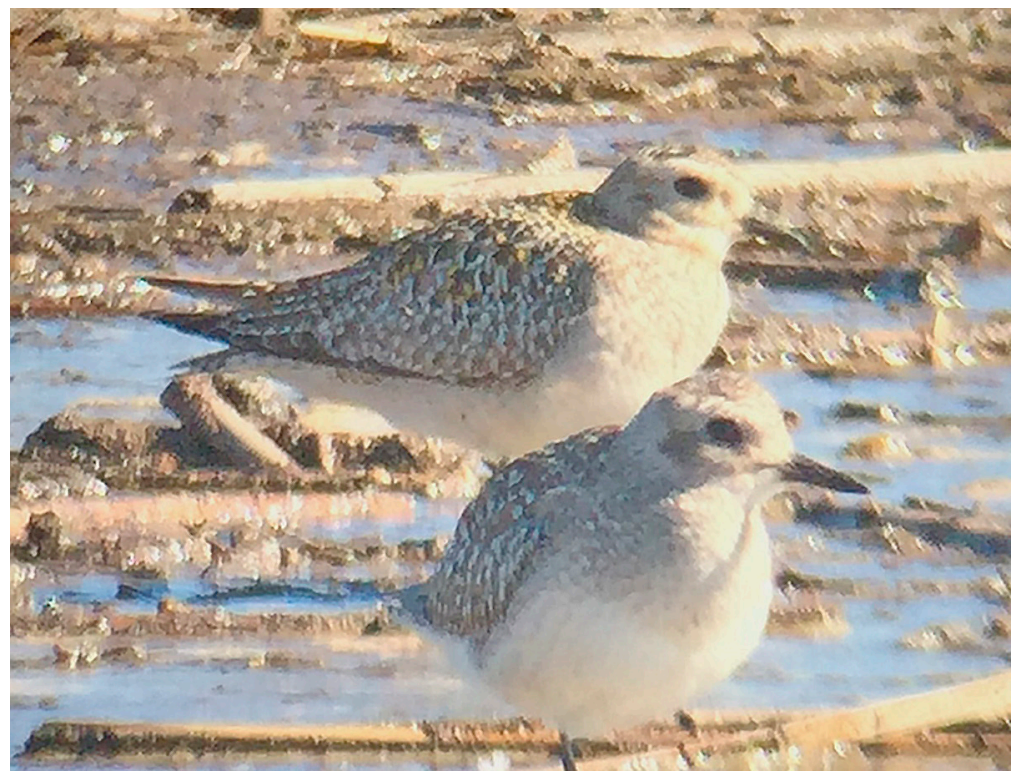

Figure 3. This golden-plover, photographed at Devereux Slough, Santa Barbara County, 29 Jan 2017 (2017-176), shows some features consistent with the European Golden-Plover, including the number of visible primary tips, number of pale spots along the edge of the longest tertial, limited replacement of scapular and upper wing feathers at this time of year, and the pattern of golden edges on the replaced lower scapulars. Lacking photos showing the diagnostic white underwing coverts, however, the committee did not accept the record.

Photo by David M. Compton

LITTLE STINT Calidris minuta $(34,3)$. An adult was at Tulare Lake Drainage District's Hacienda Basin, KIN, 21 Jul 2018 (MES†; 2018-082). California's first occurrence of two Little Stints together was of one in formative plumage at the south end of San Diego Bay NWR, SD, 16 Nov-15 Dec 2018 (MSad †: GuM; 2018-212) and an adult there 20 Oct 2018-24 Apr 2019 (PEL, GuM, MSad†; 2018-219). Most Little Stints in California have been fall vagrants between 6 July and 15 October; this adult at San Diego Bay was the first known to remain through the winter.

WHITE-RUMPED SANDPIPER Calidris fuscicollis $(31,1)$. An adult that had commenced prebasic molt at the wetlands just north of Centerville Beach County Park, HUM, 5-12 Oct 2018 (MVB†; RFow†, CNR; 2018-171) furnished the first record for Humboldt County. Of the now 10 White-rumped Sandpipers known from California in fall (15 August-11 November), all have been adults. Juveniles are evidently unrecorded in the western United States.

SPOTTED REDSHANK Tringa erythropus $(5,0)$. IDENTIFICATION NOT ESTABLISHED: One reported from Bear River Ridge Road, HUM, 17 Oct 2018 (2018-193) was not described well enough to be aged, and was stated to have yellowish-orange rather than the expected red legs, so received almost no support.

WOOD SANDPIPER Tringa glareola $(3,1)$. A juvenile at the wetlands just north 
of Centerville Beach County Park, HUM, 14-23 Sep 2018 (TF†, RFow $\dagger$, ISG $\dagger$, LH $\dagger$, $\mathrm{DK}-\mathrm{B} \dagger, \mathrm{TK} \dagger, \mathrm{KCK} \dagger, \mathrm{TGM} \dagger, \mathrm{LP} \dagger \dagger, \mathrm{CNR} \dagger ; 2018-144$; Figure 4) was only the third Wood Sandpiper for California and the first for Humboldt County. The state's two previous records were of one in first alternate plumage at China Lake, KER, 22-23 May 2007 (2007-119; Singer and Terrill 2009) and a juvenile at Camp Pendleton, SD, 24-29 Sep 2012 (2012-142; Pike et al. 2014).

MARSH SANDPIPER Tringa stagnatilis $(2,0)$. An adult in alternate plumage at the Yolo Bypass Wildlife Area, YOL, 15-21 Apr 2018 (JLD, RFow $\dagger$, PJH†, MJR $\dagger$, $\mathrm{RWR} \dagger, \mathrm{JCS} \dagger, \mathrm{KSw} \dagger ; 2018-033)$ was considered the same individual as at that locality 16-23 Apr 2016 (2016-022; McCaskie et al. 2018) and near Dixon, SOL, 9-13 Apr 2014 (2014-032; Singer et al. 2016).

THICK-BILLED MURRE Uria lomvia $(51,0)$. IDENTIFICATION NOT ESTABLISHED: The report of a distant murre photographed from shore at Redwood National Park, DN, 5 Jan 2018 (2018-004) failed to get more than half the committee's support.

BLACK-HEADED GULL Chroicocephalus ridibundus $(30,1)$. An adult in basic plumage at the Colton/San Bernardino Rapid Infiltration and Extraction Treatment Facility, Colton, SBE, 23 Dec 2018 (TAB $\dagger$, MAG $\dagger ; 2018-233$ ) was the first recorded in San Bernardino County.

BLACK-TAILED GULL Larus crassirostris $(6,1)$. An adult in alternate plumage was at Crescent City, DN, 11 Feb-11 Mar 2018 ( $L B \dagger$; RHD†, JLD, RFow $\dagger$, DK-B, $\mathrm{TK} \dagger, \mathrm{DvN} \dagger, \mathrm{LP} \dagger \dagger, \mathrm{DEQ} \dagger, \mathrm{SSt} \dagger ; 2018-022$; Figure 5). All of California’s Black-tailed Gulls have been found along the coast, with all but one occurring between 8 November and 11 March (CBRC 2007, 2020).

YELLOW-LEGGED GULL Larus michahellis $(0,0)$. IDENTIFICATION NOT ESTABLISHED: An adult gull with a mantle clearly paler than that of nearby adult California Gulls (L. californicus), reported as a possible Yellow-legged at the north end of the Salton Sea, RIV, 9 Apr 2011 (2011-284), was judged by all committee members to be an adult Herring Gull (L. argentatus) with abnormally yellow legs. A western palearctic species, the Yellow-legged Gull is a rare but almost annual visitor to Newfoundland, with additional records from Quebec and the District of Columbia, coastal Virginia, Florida, and Texas. It seems unlikely to reach California (Howell et al. 2014).

SLATY-BACKED GULL Larus schistisagus $(68,6)$. Individuals in their second plumage cycle were along the San Gabriel River in Pico Rivera, LA, 6 Jan 2018 (JFG†; MH†; 2018-002), at the Marina Landfill and Point Pinos, MTY, 5 Feb-18 Mar 2018 (BTM†; BLS †; 2018-018), and at Don Edwards San Francisco Bay NWR, SCL, 17 Mar 2018 (NA†; 2018-056). One in its third cycle was at Half Moon Bay, SM, 23 Dec 2018 (AJ†; 2018-232), as was an adult 1 Mar 2018 (AJ†; 2018-026). These were all along the coast or in the coastal lowlands where most of California's Slaty-backed Gulls have been found. An adult near Vernalis, SJ, (DGY†; 2018-073) was inland where there are few records. This primarily Asiatic gull is now recorded in all but four of the coastal counties south through Los Angeles County, around San Francisco Bay, and inland around the Sacramento/San Joaquin River delta (CBRC 2007, 2020). IDENTIFICATION NOT ESTABLISHED: The report of one in its first cycle at Point Pinos, MTY, 4 Jan 2018 (2018-086) received support from only four committee members. The majority of committee members are hesitant to endorse the identification of first-cycle Slaty-backed Gulls. While there has been much progress in understanding the field marks that define this plumage, much of it remains unpublished, and definitively eliminating other taxa (particularly hybrids) remains a challenge. 
ARCTIC LOON Gavia arctica $(16,2)$. Adults were at Abbotts Lagoon, MRN, 26 Jan-7 Feb $2018(M D \dagger, R D \dagger$, JN†; 2018-015) and on Monterey Bay near Lighthouse Point, SCZ, 2 Feb 2018 (SM†; 2018-021).

YELLOW-BILLED LOON Gavia adamsii $(104,1)$. One in formative plumage was on Tomales Bay, MRN, 15 Dec 2018-3 Jan 2019 (MVB, NW†; 2018-226). IDENTIFICATION NOT ESTABLISHED: A report of one on Lake Tahoe, PLA, 16 Apr 2018 (2018-061), was supported by distant, out-of-focus photos but lacked a description; it failed to get a majority of the committee's support.

WEDGE-RUMPED STORM-PETREL Hydrobates tethys $(14,1)$. One undergoing its second prebasic molt was photographed among a flock of Black (H. melania) and Least (H. microsoma) storm-petrels $\sim 35 \mathrm{~km}$ north-northwest of San Nicolas Island, VEN, 15 Jul 2018 (AMa†, LSa†; 2018-079). The bird was noticed only after a review of the photographs following the encounter.

TRISTRAM'S STORM-PETREL Hydrobates tristrami $(3,1)$. A juvenile photographed $\sim 35 \mathrm{~km}$ north of San Nicolas Island, VEN, 15 Jul 2018 (JBa†, DPe†, JPs†; 2018-080; Figure 6) represented California's first accepted record of a free-flying Tristram's Storm-Petrel. Like the Wedge-rumped Storm-Petrel above, this individual was not identified until photographs were reviewed after the encounter. The two previously accepted records are for Southeast Farallon Island: the first bird was captured in a mist net 22 Apr 2006 (2007-162; Singer and Terrill 2009, Warzybok et al. 2009), the second found dead 18 Mar 2015 (2015-025; Searcy et al. 2018). These are the only three photographically documented records from North America and the eastern Pacific Ocean.

JOUANIN'S PETREL Bulweria fallax $(1,0)$. IDENTIFICATION NOT ESTABLISHED: Reports of single Bulweria petrels in the Santa Barbara Channel, VEN, 5 Sep 2007 (2007-243B) and 16 km south-southwest of Strawberry Beach, SCZ, 12 Sep 2015 (2015-176) lacked sufficient details to confirm the identification as a Jouanin's Petrel; see the following account for more details.

BULWER'S/JOUANIN'S PETREL Bulweria bulwerii/fallax $(2,2)$. Both species of Bulweria have now been documented in California. Bulwer's Petrel breeds in the tropical and subtropical Atlantic and Pacific oceans, and locally in the Indian Ocean, while Jouanin's breeds in the Indian Ocean (Howell and Zufelt 2019). Jouanin's is larger and bulkier than Bulwer's, with a larger head and bill and broader wings and tail, and the pale band on the upper side of its wings is frequently less distinct (Howell 2012). There is intraspecific variation, however: in the western Pacific Bulwer's Petrels approach the smallest (presumably female) Jouanin's Petrels in bill size (S. N. G. Howell pers. comm.), potentially confounding identification of these petrels, especially given the conditions under which most pelagic observations are made. Further complicating this issue are the two all-dark species of Pseudobulweria, sightings of an unknown Bulweria around Comoros in the western Indian Ocean, and sightings of an enigmatic Pseudobulweria around New Ireland in Papua New Guinea (Howell and Zufelt 2019).

The committee re-evaluated and accepted a report of a petrel observed and photographed in the Santa Barbara Channel, VEN, 5 Sep 2007 (JPS \$\$; 2007-243A) as a Bulwer's/Jouanin's Petrel. This report had previously been reviewed and not accepted as either a Bulwer's Petrel (2007-243; Pike and Compton 2010) or a Jouanin's Petrel (2007-243B; see above). While most committee members agreed that the bird appeared too large for a Bulwer's Petrel in comparison to shearwaters in the photos, most also considered the photos too poor to confirm the identification as a Jouanin's Petrel. Likewise, the committee endorsed a report of an all-dark petrel $\sim 16 \mathrm{~km}$ south-southwest of Strawberry Beach, SCZ, 12 Sep 2015 (AMR, WB $\dagger, \mathrm{PB} \dagger$, $\mathrm{PWF} \dagger, \mathrm{RFou} \dagger, \mathrm{RG} \dagger, \mathrm{MGu}, \mathrm{CHar} \dagger, \mathrm{FHa} \dagger, \mathrm{FO} \dagger, \mathrm{DLS}, \mathrm{SBT} \dagger ; 2015-176 \mathrm{~A}$; Figure 7) as 


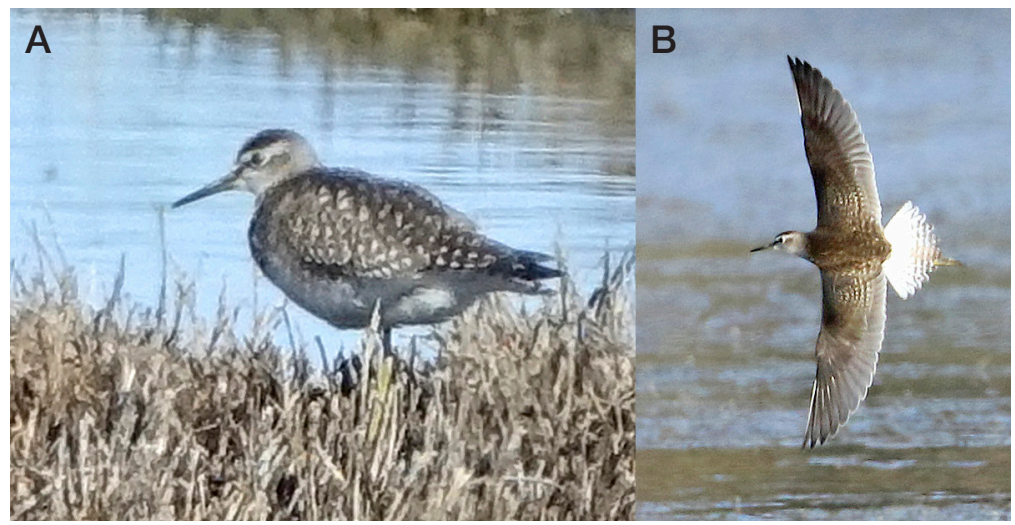

Figure 4. This juvenile Wood Sandpiper, only the third recorded in California, remained at the Centerville wetlands, Humboldt County (2018-144), for ten days, to the delight of many birders. When standing (A, taken 19 Sep 2018), this species appears similar to both the Lesser Yellowlegs (T. flavipes) and Solitary Sandpiper ( $T$. solitaria), but in flight (B, taken 16 Sep 2018) it shows the prominent white rump and tail that distinguish it from either of those two species.

Photos by Lisa Hug (A) and Linda Pittman (B)

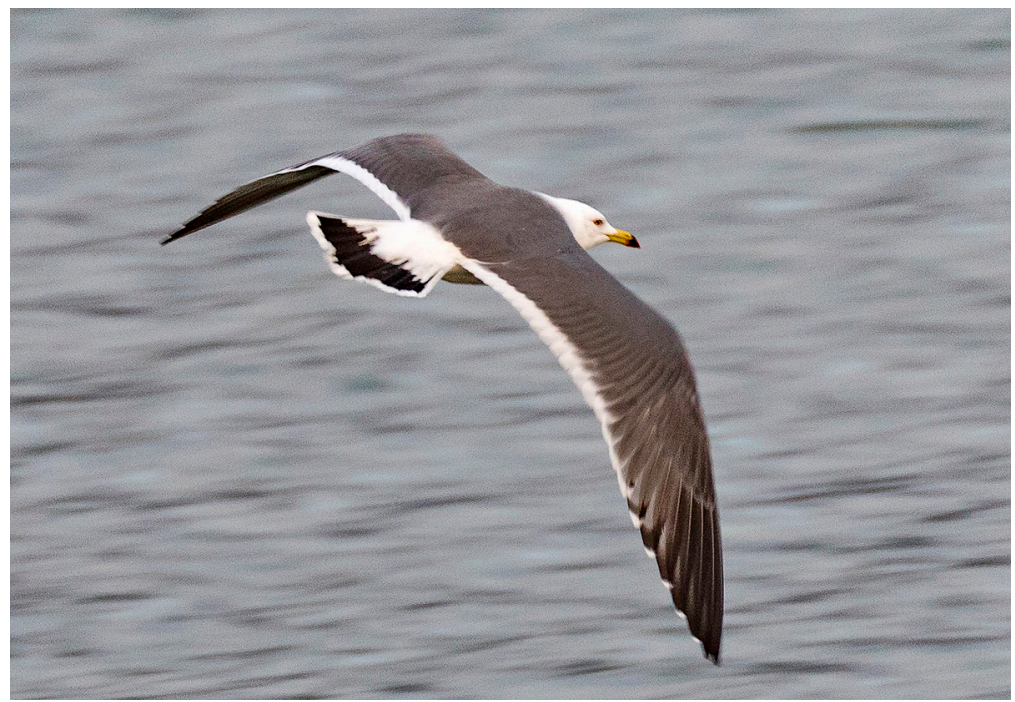

Figure 5. Taken 16 Feb 2018, this photo of the adult Black-tailed Gull at the harbor in Crescent City, Del Norte County, (2018-022), shows the eponymous broad black subterminal band on the tail. The dark slate-gray upperparts with no white mirrors on the wing tips are characteristics of the species' adult plumage.

Photo by Robert H. Doster 

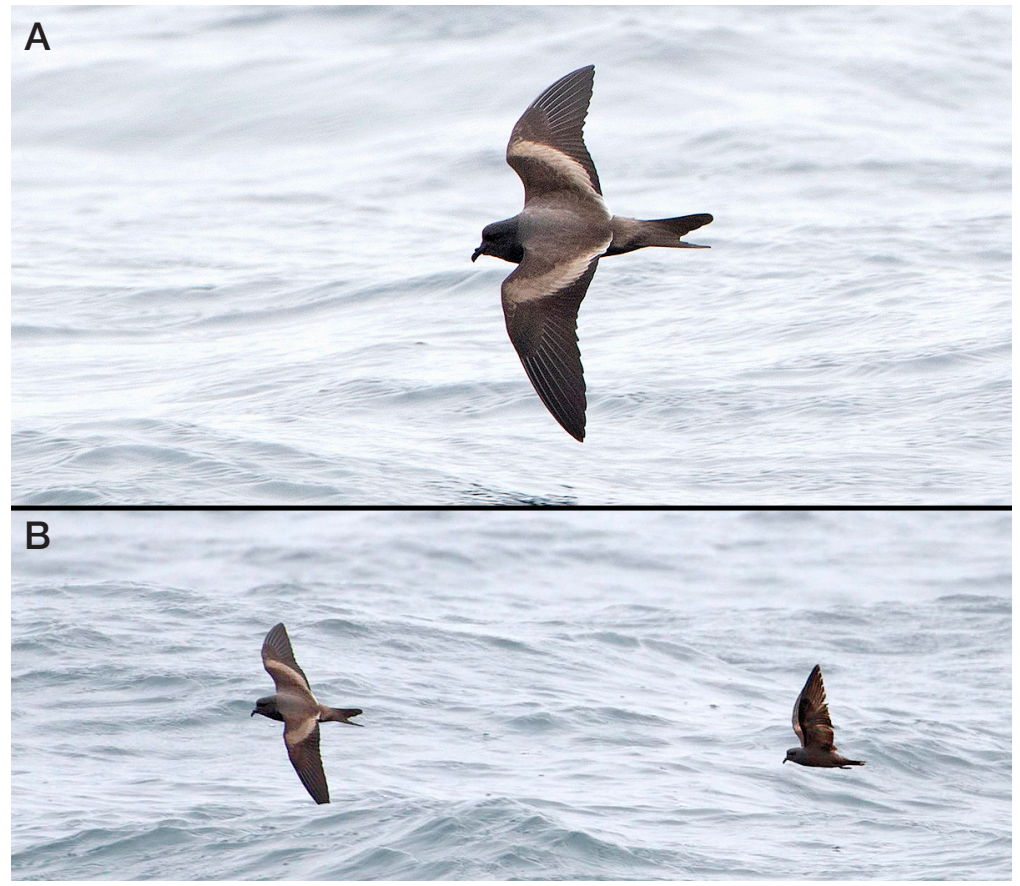

Figure 6. This juvenile Tristram's Storm-Petrel was photographed $\sim 34.8 \mathrm{~km}$ north of San Nicolas Island, Ventura County, 15 Jul 2018 (2018-080). (A) Several key field marks distinguishing this species from other large, dark storm-petrels are visible, including its bulky structure, hooded appearance, completely dark primary shafts, bold pale upper wing bands that nearly connect across the rump, rump contrastingly paler than the back and upperparts, and deeply forked tail (Kirk Zufelt pers. comm., Howell 2012). (B) The massive size of Tristram's Storm-Petrel (left) is readily apparent in comparison to a dark-rumped Leach's Storm-Petrel (H. leucorhoa chapmani, right).

Photos by David Pereksta (A) and Joel Barrett (B)

a Bulwer's/Jouanin's Petrel after not accepting it as a Jouanin's Petrel (2015-176; see above). Primarily on the basis of a thorough analysis provided by Steve Howell, the committee eventually concluded that this bird appeared too small and slender-billed for a Jouanin's Petrel. While a few committee members supported its identification as a Bulwer's Petrel, all agreed that this bird was best left unidentified to species given the mediocre photos, potential identification difficulties, and the rarity of either species in the region.

CORY'S SHEARWATER Calonectris diomedea $(3,0)$. IDENTIFICATION NOT ESTABLISHED: One was reported offshore from San Diego, SD, 27 Jul 2014 (2014188). Unfortunately, the photos were of insufficient resolution to corroborate what would have been a fourth record for California.

WEDGE-TAILED SHEARWATER Ardenna pacifica $(11,1)$. One was well described at Pt. Pinos, MTY, 1 Sep 2018 (BTM; 2018-119). 


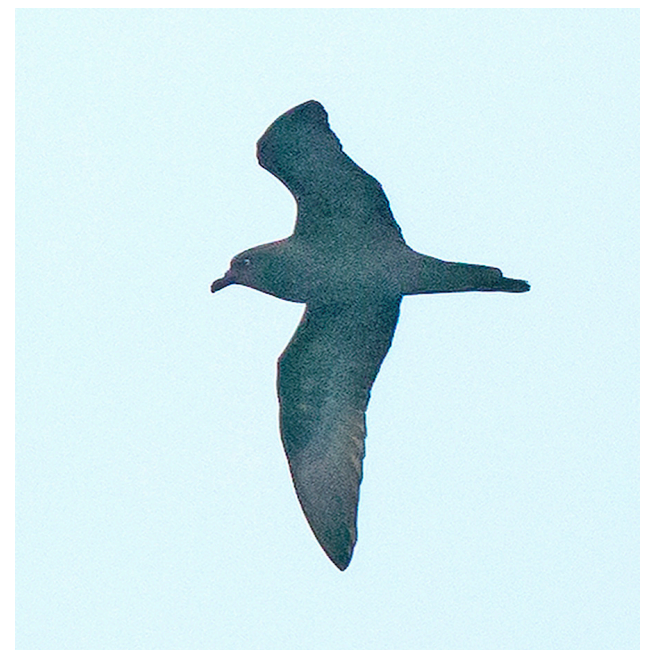

FIgURE 7. This Bulweria petrel, photographed $\sim 15.5 \mathrm{~km}$ south-southwest of Strawberry Beach, Santa Cruz County, 12 Sep 2015 (2015-176A), defied identification to species.

Photo by Chris Hartzell

MASKED BOOBY Sula dactylatra $(40,15)$. Following above-average numbers of boobies from 2015 to 2017, during the summer and fall of 2018 birders witnessed the largest incursion of Masked, Nazca, and Red-footed boobies into California yet. The overall increase in the numbers of boobies since 2015 has coincided with above-average ocean temperatures off southern California (Harvey et al. 2019). What is causing these boobies to move north from the tropics into the California Current remains uncertain, though Tompkins et al. (2017) found that a die-off of Pacific Sardines (Sardinops sagax) caused by increased ocean temperature resulted in Nazca Boobies traveling farther in search of food. The 14 Masked Booby records endorsed from 2018 represent just over one-third of all accepted records of this species for California. In southern California, individuals in their third basic plumage (having begun a second wave of primary molt and approaching definitive color) were in San Diego Bay, SD, 1 May 2018 (DSo†; 2018-040); 8.5 km west-southwest of Dana Point, ORA, 31 May 2018 (RCL†; 2018-052); at Santa Catalina Island, LA, 11 Jun 2018 (JL†‡;2018-063); and $\sim 9.5 \mathrm{~km}$ west of San Clemente Island, LA, 25 Aug 2018 (TAB $\dagger, \mathrm{TGu} \dagger, \mathrm{GTe} \dagger ; 2018-108$ ). The remaining southern California records involved individuals in their second cycle (undergoing their first molt of primaries and showing varying amounts of brown feathering on the head, back, and wing coverts): in the Los Angeles harbor, LA, 1 May 2018 (MWe†; 2018-039); 6.4 km offshore from Dana Point, ORA, 13 May 2018 (MTy†; 2018-043); 5-8 km offshore from Manhattan Beach, LA, 7 Jun 2018 (BFo $\dagger, A K L ; 2018-064)$; from Point La Jolla, SD, 9 Jun 2018 (NJD†\$, NC†, KGR †; 2018-058); 12 km southwest of Bolsa Chica State Beach, ORA, 1 Jul 2018 (MAS $\dagger ; 2018-071)$; and at Anacapa Island, VEN, 25 Sep-16 Nov 2018 (TGu, DK-B†, LSa †, AJS†, DVP $\dagger ; 2018-160$ ). Another individual in its second cycle was encountered on two different organized pelagic trips, first $\sim 27 \mathrm{~km}$ west of Point Loma, SD, 10 Jun 2018 (NC†, LE†, DPo, BR $\dagger$, MSe $\dagger$, MStr $\dagger$; 2018-059), and then again at the Thirty Mile Bank, SD, 19 Aug 2018 (MB†, NC†, $\mathrm{LE} \dagger, \mathrm{NK} \dagger, \mathrm{GuM}, \mathrm{IS} \uparrow ; 2018-099)$. The only adult Masked Booby in California in 2018 
flew past Point Pinos, MTY, 30 Nov 2018 (KB, BLS†; 2018-222). Only two other individuals, both in their third cycle, reached northern California, one at Cabrillo Canyon, SCZ, and Point Pinos, MTY, 13-19 Oct 2018 (BiH†, AMR†, BLS†, SBT; 2018-184), and the other at Southeast Farallon Island, SF, 6-7 Nov 2018 (JRT, JFG†; 2018-204). In addition to these records from 2018, the committee also endorsed one in its second cycle (with the second primary dropped) from Santa Barbara Island, SBA, 26 Oct 2015 (PAG†, NL; 2015-126). IDENTIFICATION NOT ESTABLISHED: The committee judged the documentation submitted for four reports, 2015-103A, 2018-065, 2018-098, and 2018-107, to be insufficient to eliminate the Nazca Booby conclusively; see records 2015-103, 2018-065A, 2018-098A, and 2018-107A, respectively, in the Masked/Nazca Booby account for more details.

NAZCA BOOBY Sula granti $(41,26)$. After 2017, when the number of California records almost doubled from eight to 15 (Singer et al. 2020), in 2018 the total number of state records nearly tripled, rising from 15 to 39 . One individual in its second cycle, photographed $\sim 10 \mathrm{~km}$ west of the Tijuana River mouth, SD, 10 Jun 2018 (NC $\dagger, \mathrm{LE} \dagger$, GN, DPo, BR $\dagger$, MSe†, MStr†; 2018-060), had been banded during the first half of 2017 on Isla Española, Galápagos Islands (Dave Anderson pers. comm.), indicating that at least some birds that reach California come from the Galápagos Islands, where the majority of the population breeds. The northernmost individual reported in California in 2018 was one in its second cycle $\sim 8 \mathrm{~km}$ southwest of Southeast Farallon Island, SF, 5 Jul 2018 (JCh†; 2018-101). Also in northern California, an adult $(\mathrm{MiF}+$; 2018-241) and a bird in its third cycle $(\mathrm{MiF}+; 2018-242)$ were seen together $\sim 78 \mathrm{~km}$ west-southwest of Point Sur, MTY, 26 Aug 2018. One in its second cycle at Monterey Bay, MTY, 24-26 Jun 2018 (JiS†, KSp†, EAY †; 2018-069) was considered the same individual as one in Estero Bay, SLO, 29 Jun 2018 (JoS †; 2018-104A) and again near Santa Barbara Island, SBA, 6 Oct 2018 (TGu†, DPe $\dagger$, LSa $\dagger$, CoS $\dagger$, AJS $\dagger$; 2018-177) as it traveled south along the coast. The remaining 17 records accepted by the committee were all from southern California and of birds in their second cycle unless noted: 3 km west of the Ocean Beach pier, SD, 16 Jan 2018 (BG†; 2018-010); at the Chula Vista Wildlife Reserve, SD, 1-5 May 2018 (MSad†, LSq†, PU, MWo†; SDNHM \#55680; 2018-036); on San Nicolas Island, VEN, 25 May 2018 (JHo†, MR; 2018-050); 11 km southwest of Santa Barbara Island, SBA, 15 Jul 2018 (HPR $\dagger$, LSa; 2018-081); 4 km southeast of Point Fermin, LA, 19 Jul 2018 (third cycle; KSu†; 2018-084); at County Line Beach, VEN, and Leo Carrillo State Beach, LA, 6-7 Aug 2018 (CAD†, KLG†; LACM \#121174; 2018-088); 11 km west of the San Diego River mouth, SD, 10 Aug 2018 (NC†; 2018-089); in the Los Angeles harbor, LA, 19-23 Aug 2018 (TAB†, ByO†, AH†; 2018-100); 12 km offshore from San Diego, SD, 28 Aug 2018 (DT†; 2018-116); at Santa Barbara Island, SBA, 29 Aug-4 Sep 2018 (TAB $\dagger$, JLD $\dagger$, GuM, DPe $\dagger$, AJS $\dagger$, CoS $\dagger$, GTe†; 2018-114); at Trask Knoll, $34 \mathrm{~km}$ south-southwest of Santa Rosa Island, SBA, 4 Sep 2018 (third cycle; DPe†; 2018-136); at Rodriguez Dome, 57 km west of San Miguel Island, SBA, 5 Sep 2018 (DPe†; 2018-137); at the Nine Mile Bank, SD, 23 Sep 2018 (MB†, NJD†, GuM, IS †; 2018-159); 99 km west-southwest of San Nicolas Island, VEN, 5 Oct 2018 (MiF†; 2018-243); on Platform Ellen, 14 km southwest of Huntington Beach, ORA, 6 Oct 2018 (TAB†, JMBr†; 2018-181); 189 km west-southwest of San Clemente Island, LA, 23 Oct 2018 (MiF†; 2018-244); and 189 km southwest of San Clemente Island, LA, 23 Oct 2018 (MiFt; 2018-245). The committee considered one in its second cycle seen offshore from Mission Bay, SD, 10 Jun 2018 (DJ†; 2018-196A) to be the same as one on Anacapa Island, VEN, 15 Jul 2018 (JLD †, HPR †, LSa†, JTS †, JRT; 2018-077). Single adults were $\sim 16 \mathrm{~km}$ west-southwest of Dana Point, ORA, 20 Aug 2018 (KMC†; 2018-105); 21 km southwest of San Clemente Island, LA, 6 Sep 2018 (DPe†; 2018-139); and in the Los Angeles harbor, LA, 8 Sep 2018 (TGM†, DSi; 2018-132). IDENTIFICATION NOT ESTABLISHED: The committee judged the documentation submitted for two records, 2016-141 and 2018-138, to be insufficient 
to eliminate the Masked Booby conclusively; see records 2016-141A and 2018-138A, respectively, in the Masked/Nazca Booby account for more details.

MASKED/NAZCA BOOBY Sula dactylatra/granti $(43,17)$. We received reports of several black-and-white boobies that could be identified only as this species pair. These included individuals in their second or third cycle at Point Dume, LA, 12 May 2018 (KLG\$; 2018-041); over the Thirty Mile Bank, SD, 28 May 2018 (JMM; 2018051); 1.5 km offshore from San Clemente, ORA, 23 Aug 2018 (FB ; 2018-230); at the Huntington Beach pier, ORA, 1 Sep 2018 (BED†; 2018-197); at Southeast Farallon Island, SF, 11 Oct 2018 (JFG†; 2018-190); and two on Platform Eureka, $14 \mathrm{~km}$ southwest of Huntington Beach, ORA, 13 Sep 2018 (MDH†; 2018-149). Juveniles or birds in their second cycle having just begun primary molt, without diagnostic bill color, were over the Farallon Escarpment, SF, 1 Aug 2018 (KL; 2018-087); 4 $\mathrm{km}$ south of Point Fermin, LA, 22 Aug 2018 (NS†; 2018-106); at the Tijuana River mouth, SD, 29 Aug 2018 (GN; 2018-115); and in Santa Monica Bay, LA, 31 Aug 2018 (MBI†; 2018-117). Two boobies in their second or third cycle were not accepted as Masked Boobies before being accepted as Masked/Nazca Boobies. Committee members were unable to discern the bill color of one $\sim 5-8 \mathrm{~km}$ offshore from Long Beach, LA, 15 Jun 2018 (GGe†; 2018-065A) because photos of the bird were backlit. The descriptions of another with a dull or dusky yellow bill $\sim 43 \mathrm{~km}$ west of Point Loma, SD, 17 Aug 2018 (PEL, NK†, DPo; 2018-098A) appeared to contradict photos that seemed to show some orange coloration on the bill basally. The bill color of a booby $\sim 4.1 \mathrm{~km}$ west-northwest of Pt. Pinos, MTY, 24 Aug 2018 (ST†, EH†, ALx $\dagger$, CSchwt; 2018-107A) appeared ambiguous, so the CBRC did not accept the record as representing a Masked Booby. Likewise, two boobies in their second cycle were not accepted as Nazca Boobies prior to being accepted as this species pair. One in its second cycle $\sim 53 \mathrm{~km}$ southwest of San Clemente Island, LA, 6 Sep 2018 (DPe†; 2018-138A) had replaced only its inner two juvenile primaries and not yet attained diagnostic bill coloration. An adult that flew past Point Pinos, MTY, 14 Nov 2016 (SHa, BTM; 2016-141A,) was described by one observer as having an orange bill; two committee members cited the distance and brevity of the sighting as well as the foggy conditions as reasons for not endorsing this as a Nazca Booby. Two records, 2018-196 and 2018-104, were initially accepted as of Masked/Nazca Boobies but were subsequently re-evaluated and accepted as representing Nazca Boobies; see records 2018-196A and 2018-104A, respectively, under the Nazca Booby account above for more details. Finally, the committee endorsed the identification of one in its second cycle (with the first primary dropped) from Santa Barbara Island, SBA, 27-28 Sep 2015 (NL, JSch $\dagger$; 2015-103); this record was subsequently re-evaluated, but not accepted, as a representing a Masked Booby (2015-103A). IDENTIFICATION NOT ESTABLISHED: Poor photographs of a black and white booby $\sim 28 \mathrm{~km}$ west-southwest of Bodega Head, SON, 8 Jul 2018 (2018-102) did not, to all members' satisfaction, conclusively eliminate a white-morph Red-footed Booby.

RED-FOOTED BOOBY Sula sula $(71,38)$. Like the Masked and Nazca boobies, the Red-footed Booby irrupted in unprecedented numbers along the southern California coast in 2018. Several reached northern California as well. Almost all records represented brown-morph birds in their second cycle; very few were of adults. The earliest individuals in southern California were at Point Cabrillo, SD, 6 May 2018 ( WKH, SKo †ः; 2018-038) and $\sim 6 \mathrm{~km}$ west-southwest of Dana Point, ORA, 23 Jul 2018 (HD†; 2018-085). These two forerunners were followed by 26 along the coast from August to November. In San Diego County, individuals were $\sim 18 \mathrm{~km}$ offshore from the San Diego River mouth, 9 Aug 2018 (JMM†, BMu; 2018-091); at Mission Bay, 9-10 Aug 2018 (NC†, GuM, JMM $\dagger$, JeS; 2018-090); 48 km west of Point La Jolla, 17 Aug 2018 (PEL, NK†; 2018-095); at Point Loma, 18-21 Aug 2018 (RA†, $\mathrm{MB} \dagger, \mathrm{NC} \dagger, \mathrm{GuM}, \mathrm{GLR}, \mathrm{MMT} \dagger, \mathrm{RU} \dagger ; 2018-096)$ and 13 Oct 2018 (PU†; 2018-253; 
SDNHM \#56364); 45 km west-southwest of La Jolla, 19 Aug 2018 (white morph; $\mathrm{NC} \dagger, \mathrm{LE} \dagger, \mathrm{GuM}, \mathrm{MMT} \dagger ;$ 2018-097); at Imperial Beach, 26 Aug 2018 (DPo; 2018112); at the Oceanside pier, 1-9 Sep 2018 (MB†, TPB $\dagger$, GuM, SSu†; 2018-133); and at the Nine Mile Bank, 3 Sep 2018 (DPe†; 2018-134) and 27 Oct 2018 (DPo; 2018-199). In Orange County, single birds were observed $\sim 10 \mathrm{~km}$ southwest of the Huntington Beach pier, 12 Aug 2018 (MGi†; 2018-092); 10 km south of the Newport Beach pier, 25 Aug 2018 (MGi†; 2018-109); 12 km southwest of the Huntington Beach pier, 1 Sep 2018 (MGi†; 2018-127) and $19 \mathrm{~km}$ southwest of it, 3 Sep 2018 (MGi†; 2018-126); and near or on Platform Eureka, 29 Sep 2018 (MGi†; 2018-164) and 6 Oct 2018 (BrA†, $\mathrm{TAB} \dagger, \mathrm{RBM} \dagger, \mathrm{RS} \dagger ;$ 2018-180). In Los Angeles County, individuals were encountered $\sim 4.4 \mathrm{~km}$ west-northwest of San Clemente Island 25 Aug 2018 (TAB $\dagger, \mathrm{TGu} \dagger, \mathrm{GTe} \dagger ; 2018-111)$ and in the Los Angeles harbor 17 Sep 2018 (JuM†; 2018-150). A bird initially found in the Los Angeles harbor on 15 Oct 2018 (BeA†; 2018-191) apparently wintered and was seen subsequently at the Huntington Beach pier, ORA, 9 Nov 2018 (BED†; 2018-209), $4.8 \mathrm{~km}$ offshore from there, $30 \mathrm{Dec}$ 2018 (JBo†, GLT; 2018-249), 5.3 km southwest of Dana Point, ORA, 30 Jan 2019 (BW†; 2019-010), and $\sim 12 \mathrm{~km}$ west of the Tijuana River mouth, SD, 10 Feb 2019 (GCH, CB†; 2019-015). One photographed southwest of Port Hueneme, VEN, 16 Aug 2018 (JaM†; 2018-236) was considered the same individual seen the following day off Mugu Rock and in the Santa Barbara Channel, VEN $(D V P \dagger, \mathrm{SD} \dagger, \mathrm{LBH} \dagger$; 2018-094). The only other reports from southern California through November were of three different individuals near Santa Barbara Island, SBA, 29 Aug 2018 (ARA $\dagger$, DMC, GuM, CoS $\dagger$, SBT; 2018-113), 4 Sep 2018 (DPe†; 2018-135), and 11 Oct 2018 (RK†;2018-189); one near Anacapa Island, VEN, 6 Oct 2018 (TGu†, LSa $\uparrow$, CoS†, AJS †; 2018-178); one $~ 153 \mathrm{~km}$ west-southwest of San Miguel Island, SBA, 5 Oct 2018 (MiF†; 2018-234); and one at Santa Cruz Island, SBA, 21 Nov 2018 (SKi†; 2018-216). An adult $\sim 3.5 \mathrm{~km}$ west of the Newport Beach pier, ORA, 15 Dec 2018 (KMC†; 2018-228) was one of only two birds (see 2018-249 above) seen in southern California in December. Records from northern California were of adults at Moss Landing, MTY, 1 Jul 2018 (RDC†; 2018-070) and 12-13 Aug 2018 (KCu†, CRo†, SBT; 2018-093); and subadults at Point Pinos, MTY, 25 Aug 2018 (BLS†; 2018-110); Southeast Farallon Island, SF, 5-6 Sep 2018 (JFG†, JRT; 2018-125) and 8-11 Nov 2018 (JRT, JFG †; 2018-208); 30 km south-southwest of Four Mile Beach, SCZ, 30 Sep 2018 (EH†, DLS, WV †; 2018-168); and $\sim 9.6 \mathrm{~km}$ south of Younger Lagoon, SCZ, 21 Oct 2018 (JG†, SBT; 2018-195). One flying over the eastern shore of South San Francisco Bay at Don Edwards NWR, ALA, 6 Oct 2018 (SKa†; 2018-179) represents California's only accepted record of a Red-footed Booby inland from the outer coast. Apart from the bird that wandered from the Los Angeles harbor to the Tijuana River mouth (records 2018-191, etc.), the only other long-staying Red-footed Booby that arrived in 2018 was one that roosted at Seacliff State Beach, SCZ, 1 Nov 2018-3 Jan 2019 (LPa $\dagger, \mathrm{LJ} \dagger, \mathrm{KCK} \dagger, \mathrm{SL} \dagger, \mathrm{LP} \dagger$, MJR $\dagger ; 2018-206$ ), went undetected for nearly five months, then reappeared at the same location 28 May-28 Sep 2019 ( $L J \dagger$, SL†, RWR $\dagger$, $\mathrm{AMR} \dagger, \mathrm{RaW} \dagger ;$ 2019-039). During the latter period the same individual was also observed at Seabright State Beach, SCZ, 12 Aug 2019, and Zmudowski State Beach, MTY, 20 Aug 2019. Over the 40 years from 1975 to 2014, California had only 19 accepted records, averaging one every other year. In stark contrast, 52 records were accepted during the four years from 2015 to 2018, averaging 13 per year.

TRICOLORED HERON Egretta tricolor $\left(75^{* *}, 6\right)$. Single birds undergoing preformative molt or in formative plumage were at the San Luis Rey River mouth, SD, 13 Sep-9 Oct 2018 (KLW†, PT†; 2018-143); Sweetwater Marsh at the mouth of the Sweetwater River on San Diego Bay, SD, 3 Oct 2018 (JnM†; 2018-170A); San Diego River mouth, SD, 4-11 Oct 2018 (GuM, CMo†; 2018-170B); Bolsa Chica Ecological Reserve, ORA, 14 Oct 2018 (BLM†; 2018-185); and Point Mugu Naval Air Station, VEN, 18 Oct 2018-25 Jan 2019 (JPs †; 2018-205). An adult was at Famosa Slough 
and the San Diego River mouth, SD, 19 Nov 2018-21 Mar 2019 (SBM, CRo $\dagger$, KGR †; 2018-214). Records prior to 1990 were not reviewed by the CBRC.

GLOSSY IBIS Plegadis falcinellus (40,2). Two adults were at the Woodland-Davis Clean Water Agency, YOL, 24 May-19 Jul 2018 (HoC†, JK, CDL †, DSS †; 2018-046). IDENTIFICATION NOT ESTABLISHED: One adult reported from the Susanville sewage ponds, LAS, 13 May 2018, appeared to be a hybrid with a White-faced Ibis (P. chihi; 2018-044). Another adult reported flying over Big Valley, LAS/MOD, 16 Jun 2018 (2018-072) received support from only three members during the fourth round of voting; three of the dissenting members noted that the distant photos did not show enough detail to eliminate a hybrid. Hybrids can be difficult to identify and may appear identical to either parental species (Oswald et al. 2019). Field observations and review of past records by James Pike (pers. comm.) suggest that hybrids may greatly outnumber pure Glossy Ibis in California; as a result, the committee has recently taken a more conservative approach to endorsing records of the Glossy Ibis.

ROSEATE SPOONBILL Platalea ajaja $(146,1)$. One in or molting into second basic plumage was at the south end of the Salton Sea, IMP, 17-19 Sep 2018 (CScho†, GuM; 2018-146), where the majority of California's spoonbills have occurred.

BLACK VULTURE Coragyps atratus $(11,1)$. One, just the second for Inyo County, spent nearly a month in Bishop, INY, 15 Dec 2018-11 Jan 2019 (CA†, CGl, $\mathrm{NJO} \dagger, \mathrm{RO} \dagger, \mathrm{DJH} \dagger, \mathrm{SLS} \dagger ; 2018-225)$. The committee considers the following reports to represent the same individual that has remained in the San Francisco Bay area since March 2014 (2014-027; Singer et al. 2016): Doran Regional Park, SON, 22-30 Jan 2018 (LH†, EAE†, JCS; 2018-012); Bolinas, MRN, 12 Feb 2018 (KH; 2018-024); Davenport and Wilder Ranch State Park, SCZ, and Año Nuevo State Park, SM, 15 Feb-6 Mar 2018 (BTy $\dagger$, RFi $\dagger$, AMR $\dagger$, JCS $†$; 2018-023); Point Reyes, MRN, 22-29 Apr 2018 (RD, HT; 2018-034), Point Reyes Station and Point Reyes National Seashore, MRN, 15 Jul-15 Oct 2018 (GeM, JPe†, MSc†; 2018-076); and Bolinas, MRN, 2 Dec 2018-19 Feb 2019 (EC†; 2018-220). IDENTIFICATION NOT ESTABLISHED: Two belated reports did not meet the criteria for acceptance by the committee, of one near Cambria, SLO, 20 Feb 2008 (2008-232) and one at Bishop Peak, SLO, 29 Jun 2008 (2008-233).

MISSISSIPPI KITE Ictinia mississippiensis $(53,2)$. One that had begun its second prebasic molt was along Alisal Creek in Solvang, SBA, 13-15 Jun 2018 (JR†, DMC, $\mathrm{NL}, \mathrm{BKS} \dagger, \mathrm{JuS} \dagger, \mathrm{WvD} \dagger ;$ 2018-062), and a juvenile was at Sonora Junction, MNO, 19 Sep 2018 (TJ†;2018-151). California records of the Mississippi Kite are relatively evenly split between the coast (24) and the interior (29) of the state.

COMMON BLACK HAWK Buteogallus anthracinus $(13,1)$. An adult was photographed over the Pacific Crest Trail $~ 5.5 \mathrm{~km}$ northwest of Fawnskin in the San Bernardino Mountains, SBE, on 17 May 2018 (AN†; 2018-169), the latest date for a spring migrant Common Black Hawk in California. Eight of the state's 13 records have come from the interior of southern California in spring.

GRAY HAWK Buteo plagiatus $(2,1)$. California's second Gray Hawk, an adult seemingly on territory at the Palo Verde Ecological Reserve along the Colorado River, RIV, 12 Apr-24 Jun 2018 (TAB†, GuM, WKH; 2018-032; Figure 8), was the first recorded in Riverside County. The range of the Gray Hawk extends from Costa Rica north through Central America and along the coast of the Gulf of Mexico to the Rio Grande valley of Texas and along the Pacific coast of mainland Mexico to south-central Arizona (Bibles et al. 2002, Milsap et al. 2011). The locations of known breeding nearest California are in Arizona along Date Creek and the Hassayampa River in Yavapai and Maricopa counties, respectively, $\sim 100-150 \mathrm{~km}$ east of the Colorado River (Corman and Tomoff 2015, Witzeman and Corman 2017). For a more 


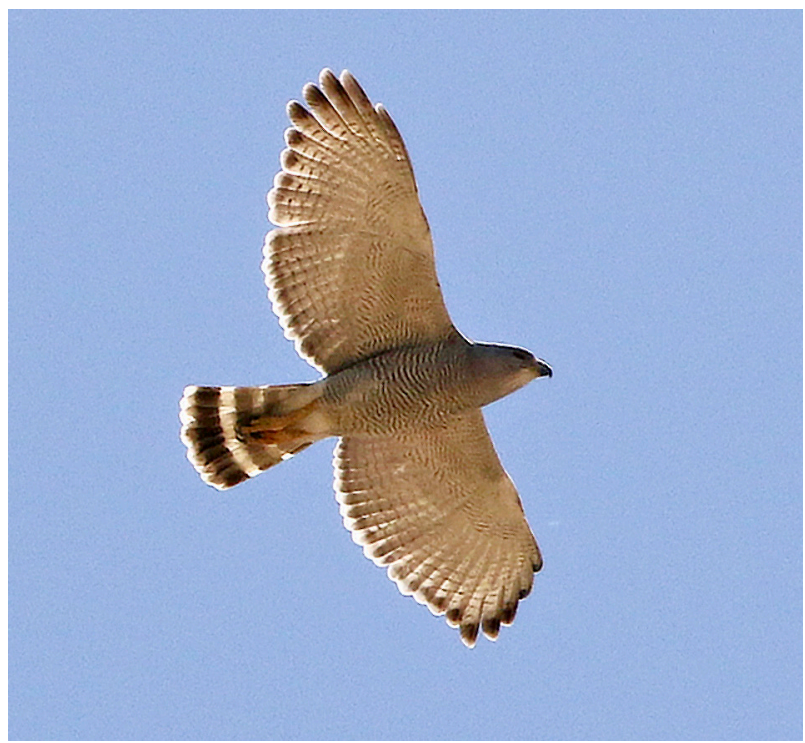

Figure 8. This long-staying adult Gray Hawk, photographed here 17 Apr 2018, at Palo Verde Ecological Reserve, Colorado River (2018-032), was the first recorded in Riverside County and second in California.

Photo by Thomas A. Benson

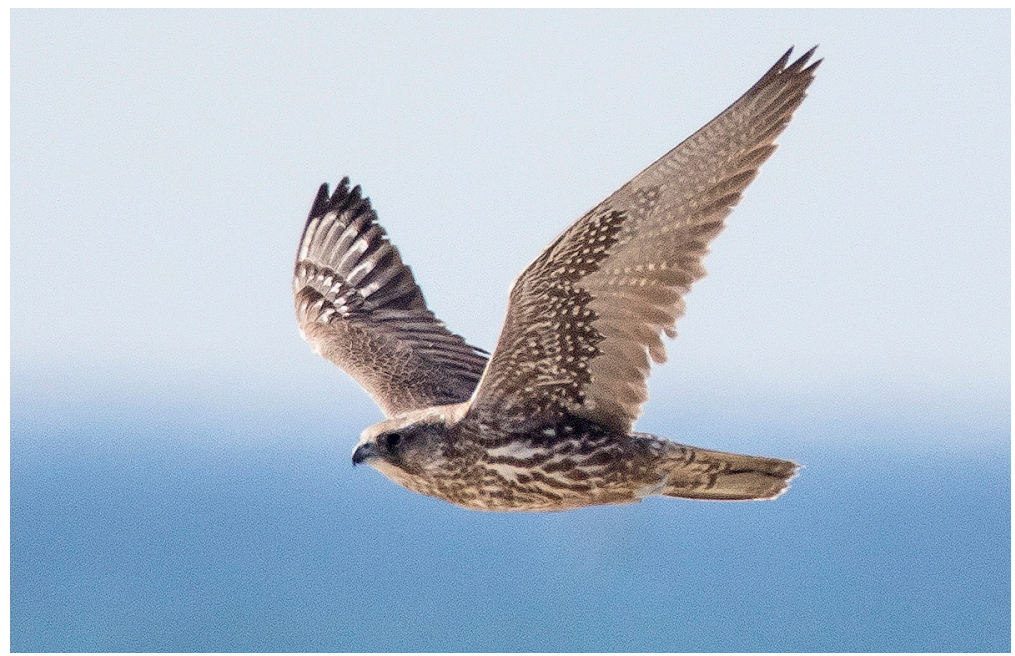

Figure 9. A bright, sunny day at the beach at the Pajaro River mouth provided unexpected circumstances for the encounter of this first-cycle Gyrfalcon, a first for Monterey County, on 3 Feb 2018 (2018-016).

Photo by Blake T. Matheson 


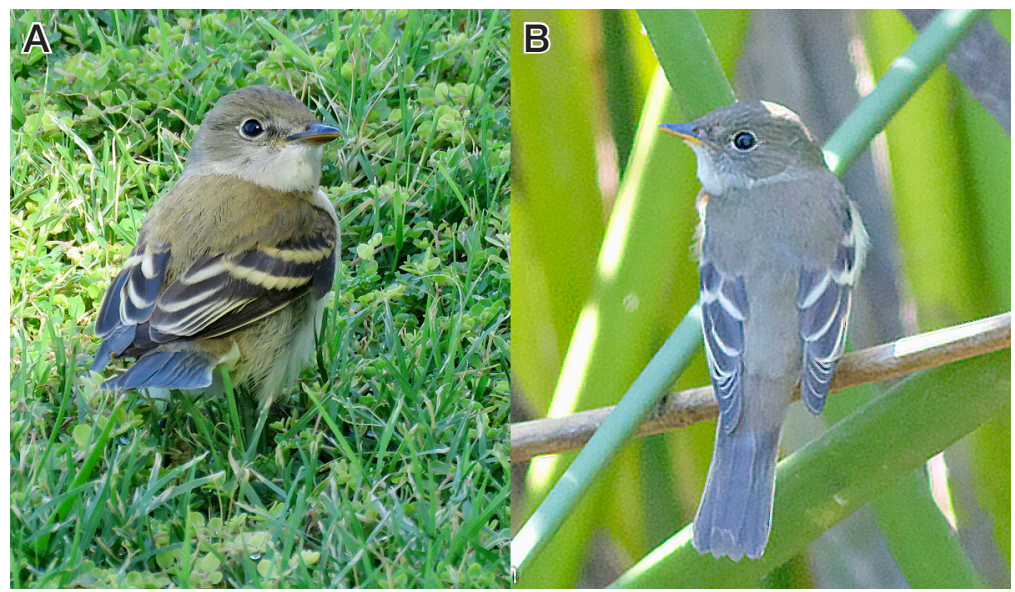

Figure 10. Alder Flycatchers at (A) Chet Huffman Park, Baker, San Bernardino County, 30 Aug 2018 and (B) Lake Los Carneros, Santa Barbara County, 30 Sep 2018. Features visible in these photos that distinguish the juvenile Alder from juveniles of at least the western subspecies of the Willow Flycatcher are the bold white edges on the tertials, yellowish (not tawny) wingbars, and greenish back lacking any brown tinge.

Photos by James E. Pike (A) and Kristie N. Nelson (B)

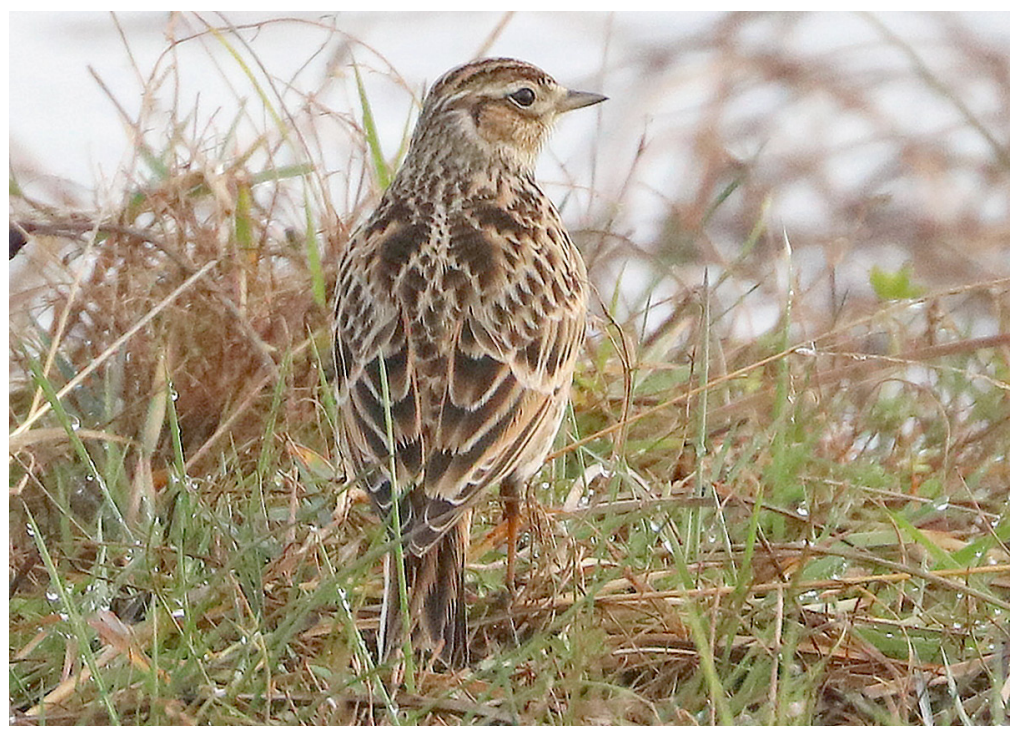

Figure 11. The second recorded in California, this Eurasian Skylark wintered at Lake Tolowa, Del Norte County (2018-210). This photo, taken 8 Dec 2018, shows the richly colored plumage and dark-centered back feathering consistent with the migratory subspecies pekinensis.

Photo by Keith C. Kwan 
thorough treatment of the status and distribution of the Gray Hawk, including extralimital records elsewhere in the U.S., see the CBRC's $38^{\text {th }}$ report (Pike et al. 2014).

ELF OWL Micrathene whitneyi $(11,0)$. A male at a confidential location in the Colorado Desert, RIV, 24 May 2018 (DAG; 2018-251) was considered the same as one there the previous year (2017-056; Singer et al. 2020).

GYRFALCON Falco rusticolus $(16,2)$. One in its first cycle (juvenile plumage) at the Pajaro River mouth, MTY/SCZ, 3 Feb-4 Mar 2018 (BTM†, RSC, CRF $\dagger$, FHo $\dagger$, LFL†, AMa, JeM, DR†, ShW; 2018-016; Figure 9) established the first records for Monterey and Santa Cruz counties. Arcata Bottoms, HUM, hosted another bird in its first cycle 31 Dec 2018-27 Mar 2019 (TK†, DK-B†, RJT†; 2018-240).

SULPHUR-BELLIED FLYCATCHER Myiodynastes luteiventris $(20,1)$. One at Palo Verde Ecological Reserve, Colorado River, RIV, 17 Jun 2018 (JMT; 2018-066) was not only the first recorded in Riverside County but the first recorded in the interior of California. Though the encounter was brief and no photos were obtained, the written details were sufficiently compelling that the committee accepted this record unanimously during the second round of voting. Additional considerations that factored into committee members' decisions were that the timing was consistent with a spring overshoot, and that the similar Streaked Flycatcher (M. maculatus) has not been recorded north of Mexico. This is only the second spring record for California, following one at Gazos Creek, SM, 14 Jun 1998 (1998-106; Erickson and Hamilton 2001).

THICK-BILLED KINGBIRD Tyrannus crassirostris $(24,0)$. An adult male returned for its ninth winter to the mouth of Poggi Canyon in Otay Valley, Chula Vista, SD, 21 Oct 2018-24 Mar 2019 (LE†, GuM, DVP†; 2018-194). One-third of California's records involve individuals that returned for multiple winters.

GREATER PEWEE Contopus pertinax $(45,2)$. One in formative plumage at Fort Rosecrans National Cemetery, Point Loma, SD, 2-3 Sep 2018 (GGi†, NJD†, JRM†; 2018-120) established California's fifth September record and its earliest date for a fall migrant by nine days (11 Sep 1991, Huntington Beach, ORA; 1991-201; Patten et al. 1995). An adult at Pacific Palisades, LA, 5-21 Oct 2018 (TGM\$, MAS†; 2018172) returned for its second consecutive year, but like the previous year's bird, was recorded only in October (2017-151; Singer et al. 2020). One at Cibola NWR in Arizona, December 1977 (Rosenberg et al. 1991), briefly crossed the Colorado River into Imperial County, 19 Dec 1977 (PM; 1977-201).

YELLOW-BELLIED FLYCATCHER Empidonax flaviventris $(29,0)$. IDENTIFICATION NOT ESTABLISHED: One was reported from Coyote Hills Regional Park, ALA, 14 Sep 2018 (2018-147). While the photos showed a round eye ring, other factors more strongly favored a Pacific-slope/Cordilleran Flycatcher (E. difficilis/ occidentalis), including the generally brownish tone to the plumage, the absence of olive breast streaking, the pattern of primary spacing, and, most importantly, the long buffy fringes on the inner secondaries (Baumann et al. 2014). While we were unable to take measurements (as would be possible with a specimen), a Yellow-bellied Flycatcher should show significantly shorter buffy fringes on the anterior edges of the secondaries, and thus a wider "secondary bar" than a Pacific-slope/Cordilleran Flycatcher (Baumann et al. 2014).

ALDER FLYCATCHER Empidonax alnorum $(8,2)$. Individuals in juvenile plumage were at Chet Huffman Park in Baker, SBE, 30 Aug 2018 (JEP†; 2018-118) and at

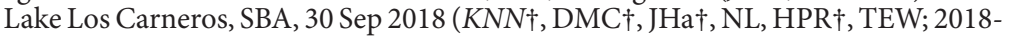
165; Figure 10), representing firsts for both counties. The latter bird was described as giving "pip" calls, while the former was not heard vocalizing. These are the first Alder Flycatchers accepted for California that were not singing males during spring 


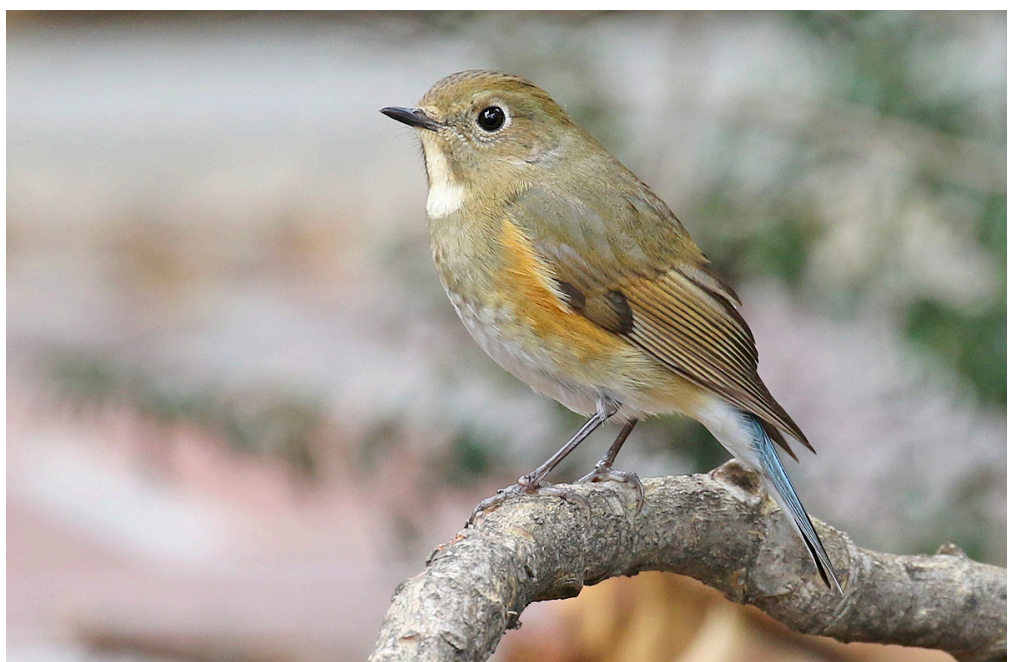

FIGURE 12. While this Red-flanked Bluetail was quite difficult to see well when first found at the William Andrews Clark Memorial Library in Los Angeles County (2018239), it became more confiding later in its stay, as demonstrated by this photo taken 9 Mar 2019.

Photo by Matthew A. Grube

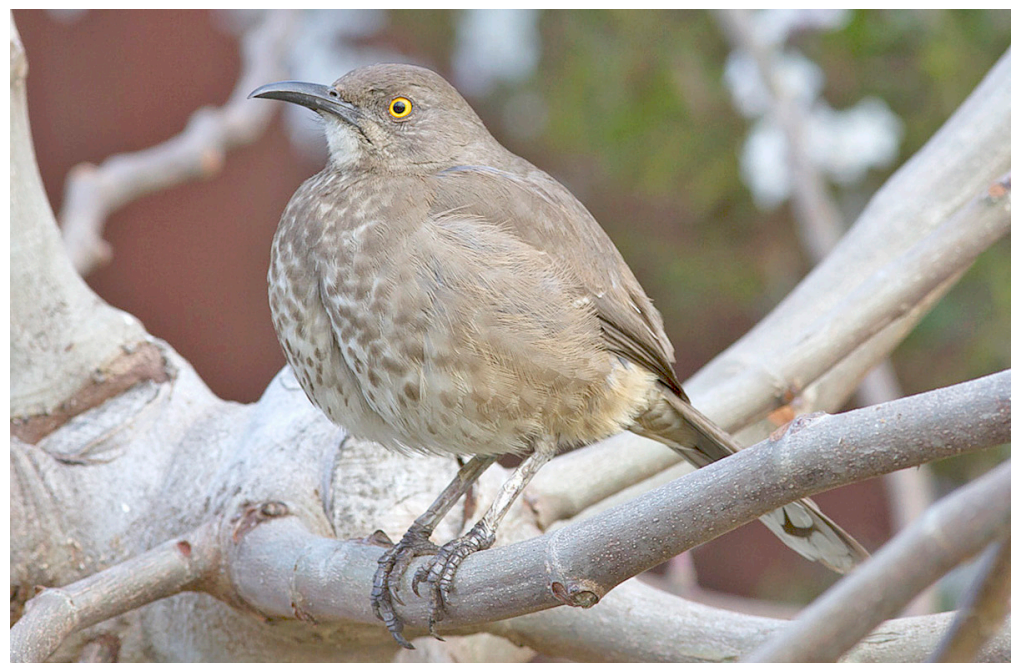

FIgURE 13. The first for northern California, this Curve-billed Thrasher wintered in Woodland, Yolo County (2018-009). This photo taken 27 Jan 2018 shows the clustered breast spotting, starkly contrasting white throat, and bright white-tipped tail feathers-plumage details specifying this individual belonged to the eastern curvirostre subspecies group, a first for California. 


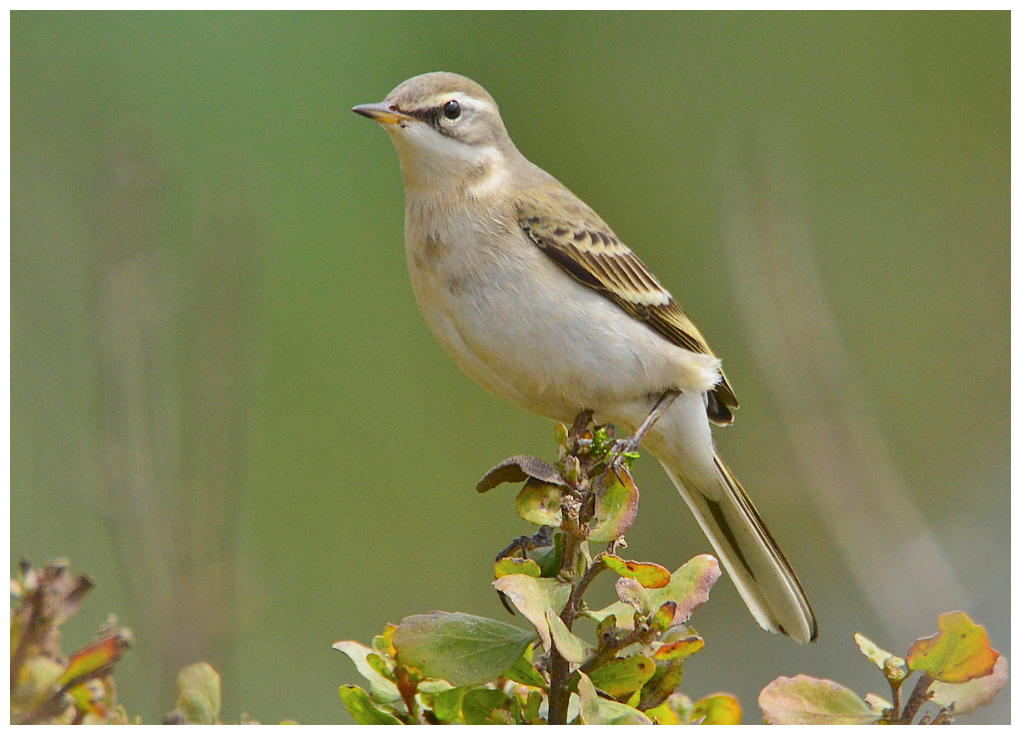

FIgURE 14. The identity of this Eastern Yellow Wagtail at Rodeo Lagoon, Marin County (2018-148), shown here on 18 Sep 2018, was confirmed with audio recordings capturing its raspy flight call.

Photo by Scott Carey

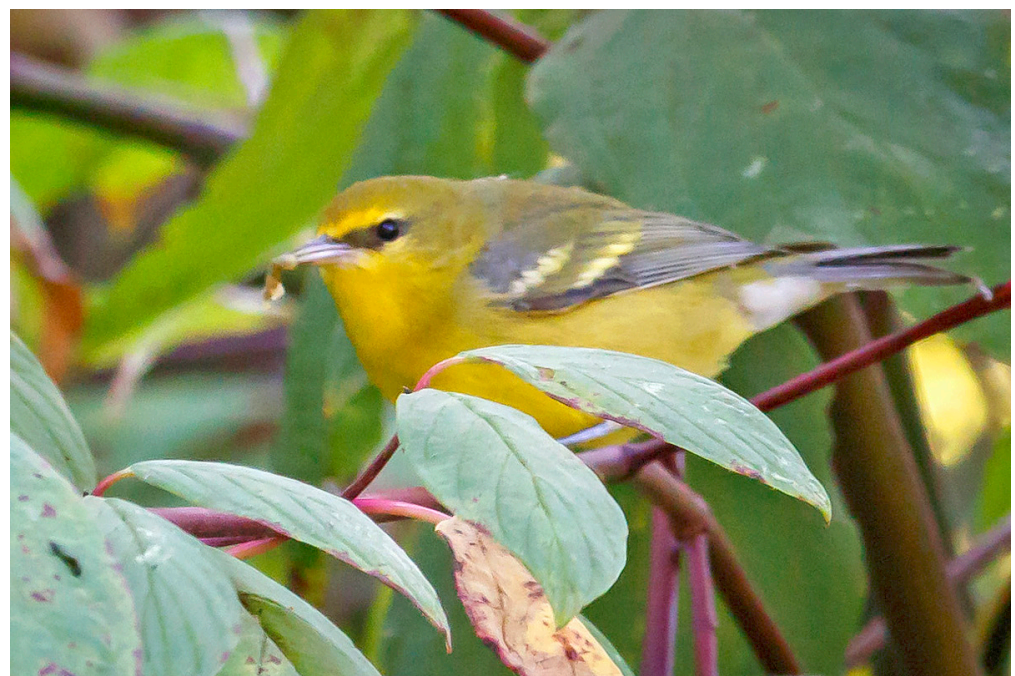

FiguRE 15. The extent of yellow in the wing bars and the olive-brown (rather than blue-gray) color of the greater coverts imply that this warbler, photographed at the mouth of the Carmel River, Monterey County, 9 Oct 2018, was a hybrid Golden-winged $\times$ Blue-winged Warbler (2018-175A). 
or summer (two records) or measured in hand during fall migration (four records; CBRC 2007). The Alder Flycatcher is very similar in plumage to the nominate subspecies of the Willow Flycatcher (E. t. traillii), making silent birds particularly difficult to identify with certainty (CBRC 2007). Eight committee members, however, judged the combination of field marks on the Baker bird-the relatively short and deep bill, obvious eye ring, rounded crown, olive back, and black wings with bold wing bars and edges to the tertials - to be more consistent with the Alder Flycatcher than with any subspecies of the Willow Flycatcher.

WHITE-EYED VIREO Vireo griseus $(86,3)$. A male in formative plumage was singing at the lower end of Refugio Creek, SBA, 1 May 2018 (TT†§; 2018-035), as was another at Oceano Campground, SLO, 1-4 Jun 2018 (PCl\$ $\$$, WK $\uparrow \$, N P+\$$, $\mathrm{BKS} \uparrow, \mathrm{MSti} \dagger, \mathrm{SBT} \uparrow \$, \mathrm{EW}+\$ ;$ 2018-053). One in formative plumage was at Muir Beach, MRN, 15 Sep 2018 (AMe†; 2018-145).

BLUE-HEADED VIREO Vireo solitarius $(88,5)$. A male in formative plumage at Elk Glen Lake, Golden Gate Park, SF, 6 Oct 2018 (FSM†; 2018-238) was considered the same as another male at Lily Pond in the same park, 9-11 Oct 2018 (RuW†, $\mathrm{HuC} \dagger$, LSw†; 2018-183). Additionally, an adult was along the Los Angeles River at Los Feliz Blvd., Los Angeles, LA, 14 Feb-28 Mar 2018 (CuS†, AB †, MAS †; 2018-027); single males in formative plumage were at Fort Rosecrans National Cemetery, Point Loma, SD, 6-7 Sep 2018 (JTS†, JCl†, GN†; 2018-140) and the Carmel River mouth, MTY, 30 Sep-11 Oct 2018 (CRo†, BiH†; 2018-176). One (age and sex unknown) was at the Mad River estuary, HUM, 10 Sep 2018 (KMS †; 2018-141). IDENTIFICATION NOT ESTABLISHED: The photos of one reported at Fort Rosecrans National Cemetery, SD, 27 Sep 2018 (2018-166) did not eliminate Cassin's Vireo (V. cassinii).

EURASIAN SKYLARK Alauda arvensis $(2,1)$. One at Lake Tolowa, DN, 12 Nov 2018-7 Jan 2019 was the second recorded in California ( $L B \dagger \$$, JMBe $\uparrow \$$, RFow $\dagger$, DK$\mathrm{B} \dagger, \mathrm{KCK} \dagger, \mathrm{OTM} \dagger, \mathrm{LPi}, \mathrm{CNR} \$ ; 2018-210$; Figure 11). Like the only previous Eurasian Skylark recorded California, which returned to Point Reyes, MRN, for seven winters beginning 16 Dec 1978 (1979-004; Luther 1980, Morlan and Erickson 1983, CBRC 2007), this individual was consistent with the long-winged, richly colored subspecies pekinensis, with dark-centered back feathers. This migratory subspecies breeds in northeastern Siberia, Kamchatka, and the Kuril Islands, wintering south to Japan, Korea, and northeastern China (Brazil 2009). It is rare but annual in spring and fall on the western Aleutian Islands (Gibson and Withrow 2015), casual in fall on the coastal mainland and Middleton Island (DeCicco et al. 2017), and has nested on the Pribilof Islands (Baicich et al. 1996). At least two individuals of this subspecies have reached Kure Atoll in the Northwestern Hawaiian Islands (Pyle and Pyle 2017).

WINTER WREN Troglodytes hiemalis $(26,3)$. One at Point San Pablo, CC, 2 Jan-20 Feb 2018 (LK\$, BTo\$; 2018-011), a first for Contra Costa County, returned for a second winter 20 Dec 2018-10 Feb 2019 (LK\$, JMBe\$, OTM\$, JCS, SBT\$; 2018-231). Individuals were also along Rincon Creek, VEN/SBA, 21 Jan-18 Feb 2018 (DPe†\$, JCaS, KKr†, CoS †; 2018-247) and at Orr Ranch, 7 km west-northwest of Galt, SAC, 28 Jan 2018 (CCS; 2018-014). All but three of the California's 26 records are supported by audio recordings, underscoring the importance of vocalizations in distinguishing this species from the Pacific Wren (T. pacificus).

RED-FLANKED BLUETAIL Tarsiger cyanurus $(3,1)$. A bird in formative plumage at the William Andrews Clark Memorial Library, Los Angeles, LA, 21 Dec 2018-22 Mar 2019 (RFM†, DWA †, DJB $\dagger, \mathrm{TAB} \dagger, \mathrm{MAC} \dagger, \mathrm{TGu} \dagger, \mathrm{MAG} \dagger, \mathrm{RH} \dagger, \mathrm{KCK} \dagger$, LJL $\dagger$, GuM, OTM $\dagger$, LPi†, CNR, ES, LSa $\dagger$, SLS; 2018-239; Figure 12) delighted many during its three-month stay. The third Red-flanked Bluetail recorded in California, this was the first at a publicly accessible location-the two known previously were on islands not open to the public: Southeast Farallon Island, SF, 1 Nov 1989 (1989- 
172; Patten and Erickson 1994) and San Clemente Island, LA, 6 Dec 2011 (2011-202; Nelson et al. 2013).

VEERY Catharus fuscescens $(16,0)$. IDENTIFICATION NOT ESTABLISHED. One was reported from Bodega Bay, SON, 5 Sep 2018 (2018-129). This species has one of the lowest acceptance rates of any on the review list. While the majority of committee members believed the description matched that of a Veery, the pitfalls of Catharus identification are manifold. The committee has always been conservative with reports of Veeries seen briefly by single observers and not photographed. Furthermore, the date of this report is two weeks earlier than the earliest accepted fall record: 19-24 Sep 1991 at Galileo Hill, KER (1991-118; Patten et al. 1995).

CURVE-BILLED THRASHER Toxostoma curvirostre $(36,1)$. The first Curvebilled Thrasher recorded in northern California was in Woodland, YOL, 6 Jan-6 Mar 2018 (KCh, TAB $\dagger$, JBro $\dagger, \mathrm{RSC} \dagger$, JLD, LF $\dagger, \mathrm{RFow} \dagger, \mathrm{SCH} \dagger, \mathrm{CHaw} \dagger, \mathrm{LH} \dagger, \mathrm{GuM}$, $\mathrm{JsM} \dagger, \mathrm{DvN} \dagger, \mathrm{LP} \dagger \dagger, \mathrm{DEQ} \dagger, \mathrm{MJR} \dagger, \mathrm{DR} \dagger, \mathrm{RAR} \dagger, \mathrm{MSe} \dagger, \mathrm{JTS} \dagger, \mathrm{JCS} \dagger, \mathrm{ANW} \dagger ; 2018-009$; Figure 13). It was in formative plumage, retaining the juvenile rectrices. From the clustered (not uniform) spotting on the white chest, a white throat with abrupt (not smoothly transitioning) dark spots at the base, distinctly edged and bright white tips to the outer tail feathers, and distinct white wing bars, this individual appeared to belong to the nominate eastern group of subspecies (curvirostre, oberholseri, and celsum), not previously reported from California (Dunn and Alderfer 2017). This group is not otherwise known to occur west of the Chiricahua Mountains in southeastern Arizona, although Phillips et al. (1964) and Monson and Phillips (1981) considered a specimen from the Pinaleño Mountains in southeastern Arizona "close to" curvirostre.

EASTERN YELLOW WAGTAIL Motacilla tschutschensis $(19,1)$. One in formative plumage was at Rodeo Lagoon, MRN, 17-20 Sep 2018 ( $W L \dagger$, SC $\dagger, \mathrm{MFo} \$, \mathrm{JsM} \dagger$, $\mathrm{DvN} \dagger, \mathrm{LPi} \dagger, \mathrm{MJR} \dagger ;$ 2018-148; Figure 14). The raspier flight call, evident in audio recordings, eliminated the Western Yellow Wagtail ( $M$. flava), and the length of the hind claw (which averages longer in the Eastern than in the Western) also supported this identification (Bot et al. 2014). It has been 10 years since California's last record (2008-110; Pike and Compton 2010). All of the state's accepted records fall within the rather narrow window of 27 August-25 September.

WHITE WAGTAIL Motacilla alba $(37,1)$. A male in formative plumage was at Fiesta Island, Mission Bay, SD, 6-7 Oct 2018 ( $D H \dagger, \mathrm{MB} \dagger, \mathrm{EGK} \dagger, \mathrm{GuM}, \mathrm{KGR} \dagger, \mathrm{RU}$; 2018-174). Since the first on 10 Feb 2013 (2013-023; Rottenborn et al. 2016), San Diego County accumulated three additional records in 2017 and 2018.

COMMON REDPOLL Acanthis flammea $(179,1)$. An adult male was in Aspendell, INY, 8-13 Jan 2018 (SLS, JLD, TH†, DJH†, CHo, RH†, NJO, RO, BS †; 2018-005).

SNOW BUNTING Plectrophenax nivalis $(142,4)$. Three were in Humboldt County: an adult female in the Arcata Bottoms, 17 Nov 2018 (MSte†\$; 2018-213), a male in formative plumage at King Salmon, 28 Nov 2018-7 Feb 2019 (MVB†, $\mathrm{DK}-\mathrm{B}, \mathrm{SV} \dagger ; 2018-218)$, and a second individual that joined it for one day, $19 \mathrm{Dec}$ 2018 (ALb;2018-250). A female was at Asilomar State Beach, MTY, 14 Nov 2018 (FD†; 2018-252).

FIELD SPARROW Spizella pusilla $(18,1)$. One in formative plumage found in the front yard of a Half Moon Bay residence, SM, 26 Jan 2018 (AJ†; 2018-013) was the first Field Sparrow recorded in San Mateo County. IDENTIFICATION NOT ESTABLISHED. A report of one at Pacific Grove, MTY, 24 Sep 2007 (2007-234) was not accepted after two rounds of voting.

LECONTE'S SPARROW Ammospiza leconteii $(40,1)$. One that had commenced preformative molt was at San Francisco Bay NWR, SCL, 7 Sep 2018 (MJM†; 2018- 


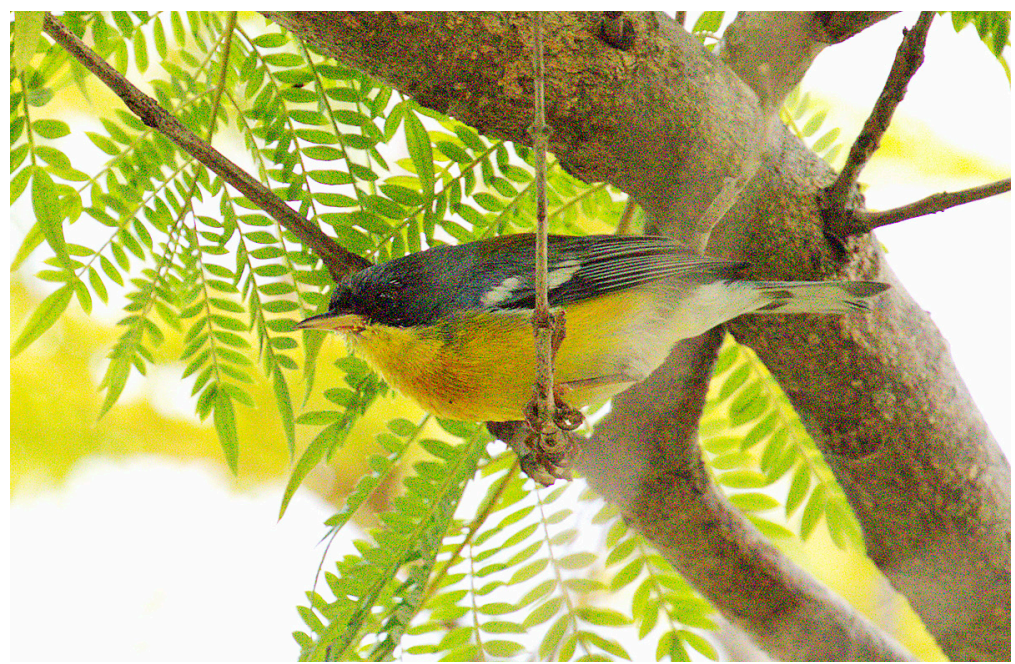

Figure 16. California's first Tropical Parula wintered in Huntington Beach, Orange County, 5 Jan-14 Feb 2018 (2018-001). This photograph, taken 7 Jan 2018, shows the extensive white on the underside of the outermost rectrices and the broad white wing bars that indicate the northwestern subspecies pulchra, which likely accounts for all records in Arizona and now California.

Photo by Curtis A. Marantz

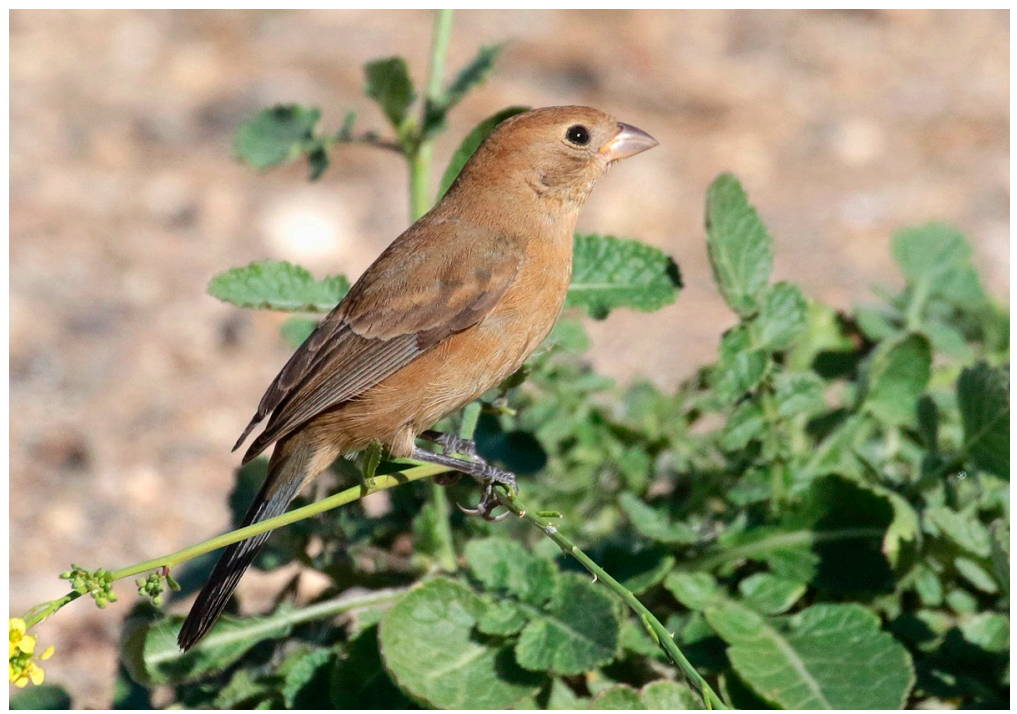

Figure 17. This Varied Bunting at Gaviota State Park, Santa Barbara County, 3 Nov 2018 (2018-201), was only the eighth for California and the first for Santa Barbara County. 


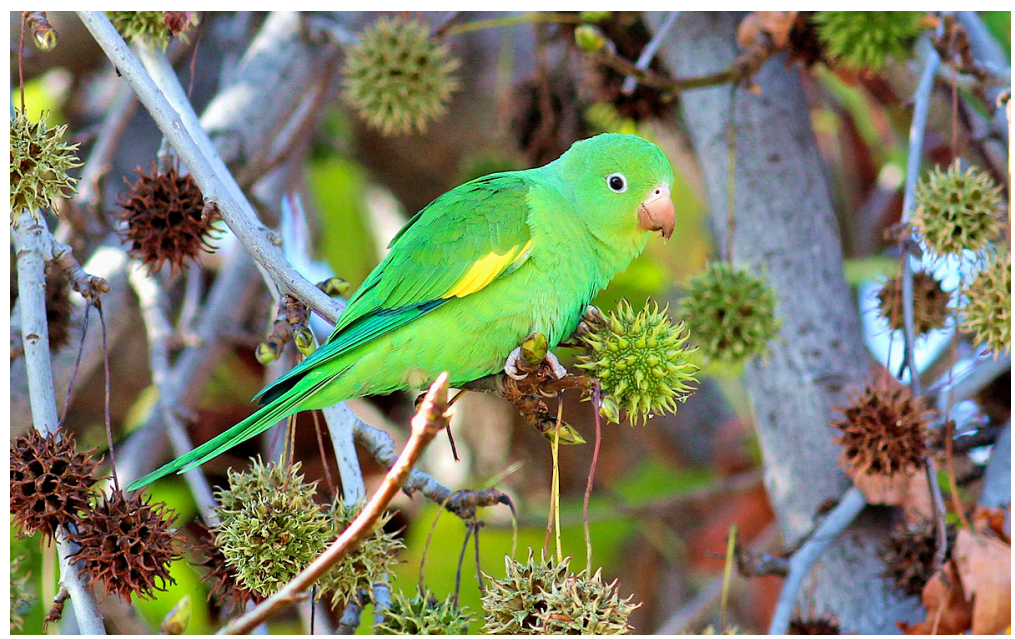

FIgURE 18. The committee recently added the Yellow-chevroned Parakeet to the California list as an established, introduced population (2019-061). This individual was photographed at Whittier Narrows Recreation Area, Los Angeles County, 31 Dec 2013.

Photo by Thomas A. Benson

130), the first for Santa Clara County. IDENTIFICATION NOT ESTABLISHED. The report of a possible LeConte's Sparrow poorly photographed at Galileo Hill, KER, 22 Oct 2015 (2015-122) garnered some support during three rounds of voting, but the documentation was ultimately deemed inadequate.

EASTERN MEADOWLARK Sturnella magna $(1,1)$. A singing male was found in Day, MOD, 10 Jun-30 Jul 2018, (LK†\$, JA†, KPA $\$$, KCK, CAM\$, GuM, MMe†, $\mathrm{JsM} \dagger$, EP\$, LSa†, BKS†; 2018-057), establishing the first record for California. Both plumage features and audio recordings identified it as belonging to the nominate

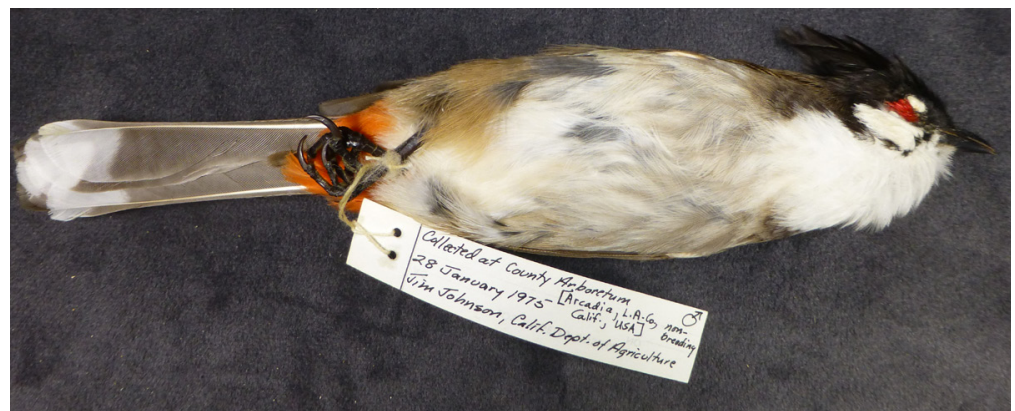

Figure 19. A series of specimens of the Red-whiskered Bulbul, including this adult male collected in Arcadia, Los Angeles County, 28 Jan 1975 (LACM 102235), provided some of the information that resulted in the committee admitting this species to the California list as an established, introduced population (2019-062).

Photo by Kimball L. Garrett 
subspecies group, not the geographically nearer subspecies lilianae. See Kahle (2019) for more information on this record, including photos and audio spectrograms, and the status of the Eastern Meadowlark in western North America.

RUSTY BLACKBIRD Euphagus carolinus $\left(67^{\star *}, 12\right)$. Females were at Bette Davis Picnic Area, Griffith Park, LA, 10 Jan 2018 ( $A B \dagger ; 2018-006)$; Moonglow Dairy, Moss Landing, MTY, 13 Jan 2018-18 Feb 2018 (LK†, BTo, DR†, SBT; 2018-007); Waller

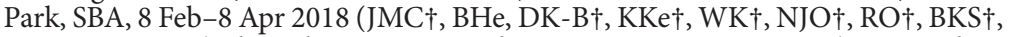
MSti†; 2018-020); the Baker sewage ponds, SBE, 26 Oct-1 Nov 2018 (two together; $J E P \dagger, \mathrm{CAM} \dagger, \mathrm{TAB} \dagger ; 2018-198$ ); San Clemente Island, LA, 4 Nov 2018 (NJD†; 2018217), Galileo Hill, KER, 5 Nov 2018 (K\&BK†; 2018-202); Buckley Ponds, 6 km east-southeast of Bishop, INY, 25 Nov 2018 (DVP†, NJO†; 2018-215); Lake Balboa, San Fernando Valley, LA, 1 Dec 2018-28 Jan 2019 (MiS†; 2018-221); and Furnace Creek Ranch, INY, 25 Dec 2018 (CHo†, $R H ;$;2018:235). A male was at King Salmon, HUM, 6-10 Nov 2018 ( $D K-B \dagger, F L$, MVB $\dagger$, RFow $\dagger$, TK $\dagger ; 2018-203$ ), and an unsexed bird was at the Baker sewage ponds, SBE, 10-14 Nov 2018 (TAB†, CAM†; 2018-207). IDENTIFICATION NOT ESTABLISHED: A report of one from Goodwin Pond, DN, 25 Dec 2018 (2018-254) included only a brief description that garnered weak support from committee members. The committee suspended reviewing reports of the Rusty Blackbird from 1975 to 2005.

COMMON GRACKLE Quiscalus quiscula $(100,2)$. Two females were both in Mono County: one at Bridgeport Reservoir, 26 May-19 Jun 2018 (RST, EAE†, DJH, $\mathrm{KNN} \dagger$, NJO $\dagger$, LST $\dagger, \mathrm{SBT} \dagger ;$ 2018-047) and another at Mono City, MNO, 2 Jun 2018 $(F J \dagger, \mathrm{KNN} \dagger ; 2018-054)$.

WORM-EATING WARBLER Helmitheros vermivorum $(135,1)$. One in formative plumage wintered at Reichmuth Park in Sacramento, SAC, 6 Jan 2018-17 Feb 2018 (JLD, CHaw $\dagger, \mathrm{DL} \dagger, \mathrm{LPi}, \mathrm{DR}, \mathrm{SBT}, \mathrm{ANW} \dagger ; 2018-003$ ), providing the first record for Sacramento County.

LOUISIANA WATERTHRUSH Parkesia motacilla $(22,1)$. One in formative plumage was at California Citrus State Historic Park, Riverside, RIV, 16 Dec 2018-13

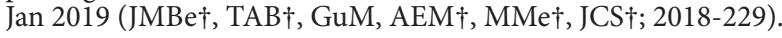

GOLDEN-WINGED WARBLER Vermivora chrysoptera $(81,3)$. A male of unknown age was at the Zzyzx Desert Studies Center, SBE, 22 May 2018 (BD†; 2018045). An adult male at Bodega Bay, SON, 5-8 Sep 2018 (DnN†\$, LH, BkO, ANW; 2018-128) was a first for Sonoma County. Another adult male was at Joshua Tree, SBE, 29 Oct 2013 (CTh†; 2013-289).

BLUE-WINGED WARBLER Vermivora cyanoptera $(54,1)$. One in formative plumage was along Carpinteria Creek, SBA, 13-15 Oct 2018 (NL, TAB $\dagger, \mathrm{AJS} \dagger ; 2018$ 186). IDENTIFICATION NOT ESTABLISHED. A report of one at the Carmel River mouth, MTY, 8-10 Oct 2018 (2018-175) apparently represented a hybrid; see record 2018-175A in the account below. A report of two from Forest Hill, PLA, 14 Jan 2017 (2017-178) failed to garner any support from committee members.

GOLDEN-WINGED $\times$ BLUE-WINGED WARBLER Vermivora chrysoptera $\times$ cyanoptera $(7,1)$. One in formative plumage at the Carmel River mouth, MTY, 8-10 Oct 2018 (BiH†, DR†, CRo†, SBT; 2018-175; Figure 15) looked much like a Bluewinged Warbler, but the yellowish-olive cast to the greater coverts and yellowish wing bars suggested the expression of Golden-winged Warbler genes.

CONNECTICUT WARBLER Oporornis agilis $(126,4)$. One in formative plumage on San Clemente Island, LA, 4-5 Sep 2018 (BFl†, NJD $\dagger$, JTS †; 2018-122) was a first for Los Angeles County. Three others on Southeast Farallon Island, SF, included birds in formative plumage 5-12 Sep 2018 (JFG†; 2018-123) and 26 Sep 2018 (JRT, DMa†; 2018-162), and one of unknown age 21 Sep 2018 (KO, JFG; 2018-155). 
Sixty-six (52\%) of California's 126 records of the Connecticut Warbler come from Southeast Farallon Island, where the shortage of vegetation makes this normally skulking migrant easier to detect (CBRC 2007, 2020).

MOURNING WARBLER Geothlypis philadelphia $(163,3)$. In 2018 Southeast Farallon Island, SF, hosted two birds in formative plumage: one of undetermined sex 5-9 Sep 2018 (JFG†; 2018-124) and a male 22-28 Sep 2018 (JFG†, JRT; 2018-156). The report of another of undetermined age there 29 Sep 2014 (OJ;2014-185) was also accepted. As with the Connecticut Warbler, Southeast Farallon Island is responsible for a significant portion (71 individuals, or 44\%) of the Mourning Warbler records for California. IDENTIFICATION NOT ESTABLISHED. After two circulations, the report of one at Golden Gate Park, SF, 15 Oct 2018 (2018-237) did not receive enough votes for acceptance.

CAPE MAY WARBLER Setophaga tigrina $\left(48^{* *}, 4\right)$. Males in formative plumage were at Todd Park in Blythe, RIV, 3 Feb 2018 (TGo $\dagger ; 2018-017$ ) and the Zzyzx Desert Studies Center, SBE, 14 Oct 2018 (CL†; 2018-188), while adult males were at San Clemente Island, LA, 19-27 Sep 2018 (JTS †, NJD; 2018-152) and Shoshone, INY, 20 Sep 2018 (JEP $\dagger ; 2018-158)$. IDENTIFICATION NOT ESTABLISHED. One reported from Endert Beach Road, DN, 25 Jun 2018 (2018-068) failed to receive committee endorsement. The committee reviews records of the Cape May Warbler from 1972 to 1974 and 2011 onward.

TROPICAL PARULA Setophaga pitiayumi $(1,1)$. A male in formative plumage wintered in Huntington Beach, ORA, 5 Jan-14 Feb 2018 (JEP†, DJP $\dagger, \mathrm{TAB} \dagger$, JLD, TGu $\dagger, \mathrm{CAM} \dagger, \mathrm{GuM}, \mathrm{MME} \dagger, \mathrm{LP} i \dagger, \mathrm{DR} \dagger, \mathrm{ES} \dagger, \mathrm{CSchu} \neq, \mathrm{RS} \dagger, \mathrm{MSe} \dagger, \mathrm{DSi} \$, \mathrm{SLS}$, $\mathrm{JCS} \dagger, \mathrm{MMT} \dagger, \mathrm{SBT} \dagger, \mathrm{RSW} \dagger ; 2018-001$; Figure 16). It was the first Tropical Parula for California and the first to winter in the United States west of Texas. This individual showed extensive white on the underside of the outermost rectrices and relatively broad white wing bars, indicating the northwestern subspecies pulchra, which breeds as far north as Sonora, Mexico (Regelski and Moldenhauer 2012). Comprising nine subspecies, the Tropical Parula is a widely distributed resident in the forests of South America (though absent from the Amazon Basin), Central America, and Mexico (Regelski and Moldenhauer 2012). The northernmost breeding populations, in southern Texas in the United States (S. p. nigrilora) and in Sonora and Chihuahua in northern Mexico (S. p. pulchra), generally migrate south for the winter, though small numbers remain in these regions year round (Regelski and Moldenhauser 2012). The Tropical Parula is a casual visitor elsewhere in Texas, and in Baja California Sur (five records), Arizona (nine records), New Mexico (one record; not reviewed by the New Mexico Bird Records Committee), Colorado (one record), and Louisiana (five records). These variously represent spring migrants overshooting the breeding range, post-breeding visitors, and (in Louisiana) wintering birds (Dunn and Garrett 1997, Leatherman and Mammoser 2007, Iliff et al. 2008, Lockwood and Freeman 2004, Rosenberg et al. 2017, N. Am. Birds 59:474, 631, Lauren Harter pers. comm.).

PINE WARBLER Setophaga pinus $\left(119^{\star *}, 1\right)$. One was at John Anson Ford Park in Bell Gardens, LA, 17 Nov 2006 (JSF\$; 2006-229). The CBRC reviews records of this species through 2013.

GRACE'S WARBLER Setophaga graciae $(79,7)$. Three individuals wintered in San Diego County, including an adult at Del Mar, 5 Feb-1 Apr 2018 (PEL, JBru†, $\mathrm{NC} \dagger, \mathrm{LMD} \dagger, \mathrm{DK}-\mathrm{B} \dagger, \mathrm{TR} \dagger, \mathrm{MSe} \dagger, \mathrm{SES} \$ \$ ;$ 2018-019) and an adult male in Encinitas, 7 Dec 2018-26 Mar 2019 (SES\$, MB†, SB†, EM†, OTM†, LPi†; 2018-223). The committee considered the third, an adult at Villa La Jolla Park, 14 Oct 2018-5 Apr 2019 (GN†, PCh; 2018-187), to be a returning individual (2017-098; Singer et al. 2020). A female in formative plumage was at Encinitas, SD, 4-5 Oct 2018 (MTu†; 2018-173). One in formative plumage at Rancho Santa Ana Botanic Garden, Clare- 
mont, LA, 7-8 Apr 2018 ( $D T R \dagger, \mathrm{TAB} \dagger \$, \mathrm{ML} \dagger ; 2018-030$ ) had likely wintered locally. One was near Blue Ridge Campground in the San Gabriel Mountains, LA, 5 May 2018 (CMcF; 2018-042). The first record for Mono County was of a singing male in formative plumage along Bald Mountain Road near June Lake, 24 May-13 Aug

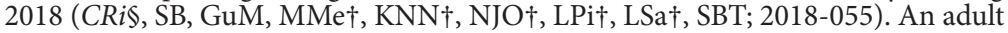
male was at the Chilao Visitor Center, San Gabriel Mountains, LA, 15-28 Jul 2018 $(\mathrm{LMB} \dagger, \mathrm{DJB} \dagger, \mathrm{TGM} \dagger, \mathrm{ES}, \mathrm{JCS} \dagger ;$ 2018-078).

VARIED BUNTING Passerina versicolor $(8,1)$. An adult female at Gaviota State Park, SBA, 3 Nov 2018 (WTF†; 2018-201; Figure 17) was the first Varied Bunting for Santa Barbara County.

\section{POPULATIONS ACCEPTED}

In addition to evaluating and archiving records of birds that rarely occur in California, the committee also maintains a California bird list, which includes introduced species considered to be established in the state. For a species to be added to the list, its identification must be established and its population in the state must be considered "viable." The committee's criteria for viability are (1) that the species has bred in the state for 15 consecutive years, (2) that the population is increasing or stabilized after an initial period of increase, (3) that the species occupies enough geographically contiguous suitable habitat that the population is unlikely to diminish significantly, and (4) that the occupied environment is ecologically similar enough to the species' native habitat, or to that of other successful introductions, that permanent establishment seems likely. Populations maintained primarily by continued releases or requiring intensive management are not considered viable.

YELLOW-CHEVRONED PARAKEET Brotogeris chiriri. The CBRC's Introduced Birds Subcommittee (T. A. Benson, J. S. Feenstra, J. F. Garrett, K. L. Garrett, K. N. Nelson, and A. J. Searcy) gathered evidence that naturalized populations of this species have met the criteria for addition to the California list. The full committee accepted their proposal (2019-061; Figure 18). Yellow-chevroned Parakeets have been reported in the wild in California since at least the 1980s, the result of some of the tens of thousands of birds imported for the pet trade between 1977 and 1990 (Brightsmith et al. 2017) escaping captivity. Substantial populations were noted during the 1990s, and the population has continued to increase slowly and steadily in both size and geographic range since then, now likely numbering over 1000 individuals (Garrett 2018). Breeding was not documented until 1997, although the species was clearly naturalized here before then. It ranges across the coastal lowlands of Los Angeles County and northwestern Orange County, with the largest numbers in the western San Gabriel Valley and the Los Angeles Basin west of the Los Angeles River. Small flocks noted in the south San Francisco Bay area from 2000 to 2014 did not represent a self-sustaining population, nor do occasional reports away from the greater Los Angeles area. A series of seven specimens from southern California populations at the Los Angeles County Museum of Natural History documents that the established subspecies is B. c. chiriri, widespread in much of east-central South America. This subspecies is characterized by green undersides of the rectrices (lacking a strong hint of blue), a yellowish tinge to the body feathers, and males with wing chord $<126 \mathrm{~mm}$ (Brightsmith et al. 2017).

RED-WHISKERED BULBUL Pycnonotus jocosus. The committee likewise accepted the Introduced Birds Subcommittee's proposal (2019-062; Figure 19) summarizing evidence that a naturalized population of this species has met the criteria 
for addition to the California list. Red-whiskered Bulbuls were first reported in the wild in southern California in 1968 (Barber 1985), and likely started breeding shortly after that. A small population became established in the vicinity of San Marino and Arcadia in Los Angeles County, but the species was deemed an agricultural pest and subjected to intensive eradication efforts by the California Department of Food and Agriculture from 1968 to 1984 (Hitchcock 1987, Allen et al. 2016). These efforts were abandoned in 1985, and the population has slowly but steadily increased since then, and now probably numbers over 500 individuals. The highest numbers are concentrated in the Pasadena-San Marino-Arcadia area, but the species occurs widely throughout the western San Gabriel Valley, and sparsely in the eastern San Gabriel Valley, San Fernando Valley, and along the southeastern edge of the Santa Monica Mountains. Scattered sightings elsewhere in Los Angeles County, and in Ventura, Orange, and western San Bernardino counties, likely represent birds dispersing from the naturalized population, though some may represent local escapees. Specimens from southern California populations have not been identified to subspecies but are consistent with P. j. jocosus of southeastern China and P. j. emeria of eastern India. The latter is the subspecies established in Florida (Banks and Laybourne 1968).

\section{MISCELLANEOUS}

The long-staying Northern Gannet (Morus bassanus; 2012-058) first seen at Southeast Farallon Island, SF, 25 Apr 2012 (Pike et al. 2014), and the female Common Black Hawk (2005-060 et al.) resident near Santa Rosa, SON, since 14 May 2005 (Iliff et al. 2007), were both still present through 31 Dec 2018.

\section{CORRIGENDA}

The committee's $43^{\text {rd }}$ report (Singer et al. 2020) contained a few errors that were discovered after publication. Incorrect dates were provided for two records: the correct date for the Yellow-bellied Flycatcher reported at Point Reyes National Seashore, MRN (2017-149) was 23-24 Sep 2017, and for the Dusky Warbler (Phylloscopus fuscatus) at Coyote Point, SM (2017-101), was 8-10 Oct 2017. We omitted the dates for the Mourning Warbler at Point Reyes NS, MRN, 11-17 Sep 2017 (2017-081). The White-winged Crossbill (Loxia leucoptera) at Big Lagoon, HUM, 21 Dec 2017 (Tom Leskiw; 2017-173) was accepted, bringing the number of records accepted in the $43^{\text {rd }}$ report to six and the total number to 18 . We also correct the dates for the following four records from San Bernardino County that were previously published incorrectly. The Wood Thrush (Hylocichla mustelina) at Mountain Home Village (1996-161; McCaskie and San Miguel 1999) was present 21-24 Dec 1996. The Curve-billed Thrasher at Big River (2006-177; Heindel and Garrett 2008) was present 30-31 Oct 2006; the correct dates were published initially, but the corrigenda of the $33^{\text {rd }}$ report (Singer and Terrill 2009) amended the date incorrectly as 1 Nov 2006. The Streak-backed Oriole (Icterus pustulatus) at the Zzyzx Desert Studies Center (2006-145; Heindel and Garrett 2008) was present 9-14 Oct 2006. The Red-faced Warbler (Cardellina rubrifrons) at Green Canyon (2007-146; Singer and Terrill 2009) was present 26 Jun-20 Jul 2007. The committee recently received documentation that one of two Mourning Warblers on Southeast Farallon Island, SF, 26 Sep 2005 (2008-011 and 2008-012; Singer and Terrill 2009) was also present the following day. Without knowing which individual was present for a second day, the committee arbitrarily extended the date of record 2008-011 to 26-27 Sep 2005. Finally, following a review of Common Black Hawk records in northern California, the committee now considers the one near Aromas, SBT, 31 Mar 2008 (2008-055; Pike and Compton 2010) to be different from the long-staying bird near Santa Rosa, SON (2005-060 et al.; Iliff et al. 2007). 


\section{ACKNOWLEDGMENTS}

Printing of this report was facilitated by donations from past and current CBRC members. Lisa Ballance and the Marine Mammal and Turtle Division of the NOAA Southwest Fisheries Science Center provided information on booby sightings from the 2018 California Current Ecosystem Survey. Chris Gooddie, Killian Mullarney, Rick Simpson, and Lars Svensson provided expert opinion on the European GoldenPlover record, and Steven N. G. Howell provided helpful discussion of identification of Bulwer's and Jouanin's petrels. We extend our gratitude to James R. Tietz for maintaining the Update to Rare Birds of California (www.californiabirds.org/ cbrc_book/update.pdf) and to Joseph Morlan for maintaining the CBRC's website (www.californiabirds.org). The following past and present CBRC members provided comments on drafts of the manuscript: Jon L. Dunn, James E. Pike, Peter Pyle, Stephen C. Rottenborn, Adam J. Searcy, Daniel S. Singer, and Ryan S. Terrill. We also thank Philip Unitt, Daniel D. Gibson, and Ryan P. O'Donnell for their review and comments on the draft report.

Finally, the CBRC would not exist without the cooperation of birders and ornithologists throughout California. We especially thank the following people who contributed documentation for records included in this report: Taylor Abbott, Alex R. Abela, Josh Able, Kenneth P. Able, Douglas W. Aguillard, Bruce Aird (BrA), Chris Allen, Bernardo Alps (BeA), Ryan Andrews, Noah Arthur, Mario V. Balitbit, Karl Bardon, David J. Barton, Joel Barrett (JBa), Lance M. Benner, Jonah M. Benningfield (JMBe), Thomas A. Benson, Joachim Bertrands (JBe), Matthew Binns, Andrew Birch, Rick Bisaccia, Jay Boch (JBo), Stevan Brad, Terence P. Brashear, Jeff M. Bray (JMBr), Frank Brennan, Jean Broadhvest (JBro), Will Brooks, Chris Brown, Lucas Brug, John Bruin (JBru), Paul Budde, John Callender (JCa), Kristin M. Campbell, Ryan D. Carle, Scott Carey, Paul Chad (PCh), Mark A. Chappell, Julie Chase (JCh), Jamie M. Chavez, Kelly Childress (KCh), Nancy Christensen, Richard S. Cimino, Everett Clark, Petra Clayton (PCl), Jeff Clingan (JCl), Holly Coates (HoC), David M. Compton, Chris Conard, Lucas Corneliussen, Hugh Cotter $(\mathrm{HuC})$, Rebecca F. Coulter, Kate Cummings (KCu), Brian E. Daniels, Frank Daugherty, Christine A. Dean, Bill Deppe, Nicole J. Desnoyers, Mark Dettling, Ryan DiGaudio, Leroy M. Dorman, Harold Dorr, Robert H. Doster, Sierra Downes, Jon L. Dunn, Suzette Eagler, Mark W. Eaton, Larry Edwards, Randy Ehler, Elias A. Elias, Jon S. Feenstra, Paul W. Fenwick, Robbie Fischer (RFi), Brian Flick (BFl), Leslie Flint, Frank Fogarty, Michael Force (MiF), Nicolas Forestell, Bruce Forman (BFo), Mark Forney (MFo), Craig R. Fosdick, Rick Fournier (RFou), Rob Fowler (RFow), Teale Fristoe, Wes T. Fritz, Collette Gaal, Peter A. Gaede, Jim Gain, John F. Garrett, Kimball L. Garrett, Melissa Gates (MGa), Gregg Gentry (GGe), Greg Gillson (GGi), Mark Girardeau (MGi), Ian S. Gledhill, Mayra Gonzalez (MGon), David A. Goodward, Tawni Gotbaum (TGo), Matt Gould (MGou), Rob Gowan, Benjamin Griffith, Matthew A. Grube, Trish Gussler (TGu), Mary Gustafson (MGu), Skye Haas (SHa), Tonya M. Haff, Elizabeth Hamel, Steve C. Hampton, Keith Hansen, Jeff Hanson (JHa), Michael D. Harris, Lauren B. Harter, Chris Hartzell (CHar), Frank Hawkins (FHa), Cliff Hawley (CHaw), William K. Hayes, Gjon C. Hazard, Tom Heindel, Bruce Henderson (BHe), Bill Hill (BiH), Brad Hines (BrH), Fred Hochstaedter (FHo), Sarah Hockensmith (SHo), Justin Hoesterey (JHo), David Holway, Deborah J. House, Chris Howard (CHo), Rosie Howard, Andrew Howe, Mike Huang, Lisa Hug, Paul J. Hurtado, Mark B. Indictor, Charles Jackson, Edwin Jacobo, Lee Jaffe, Oliver James, Alvaro Jaramillo, Donel Jensen, Tom Johnson, Foster Jones, Logan Kahle, Eric G. Kallen, Deven Kammerichs-Berke, Sanjay Karanth (SKa), Kevin Keirn (KKe), Simon Kiacz (SKi), Glenn Kincaid, Will Knowlton, Nicole Koeltzow, Steve Kolodziey (SKo), Jesse Kramer, Rebecca Krantz, Karl Krause (KKr), Tony Kurz, Keith C. Kwan, Ken and Brenda Kyle, Anne K. LaHue, Jack LaLonde, Alexandra Lamb (ALb), Alex 
Lamoreaux (ALx), Fanter Lane, Lisa F. Larson, Susan LeClair, Derek Lecy, William Legge, Paul E. Lehman, Joan E. Lentz, Linda J. LeRoy, Gary S. Lester, Nick Lethaby, Kirsten Lindquist, Christopher Lindsey, Mickey Long, Ethan Longhenry, Calvin D. Lou, Robin C. Lowe, Paul Mack, Aaron Maizlish (AMa), Michael J. Mammoser, Curtis A. Marantz, Frank S. Marino, Justin Marquez (JuM), Rebecca F. Marschall, Eve Martin, John Martin (JnM), Barry L. Mast, Blake T. Matheson, Dan Maxwell (DMa), Sara B. Mayers, Guy McCaskie (GuM), Gerry McChesney (GeM), James McClain (JaM), Mike McClintock (MMcC), Catherine McFadden (CMcF), Chet McGaugh (CMcG), Jimmy M. McMorran, Robert B. McNab, Alex Merritt (AMe), Anthony E. Metcalf, Martin Meyers (MMe), Thomas G. Miko, Jeff Miller (JeM), Betsy Mooney (BMo), Joseph Morlan (JsM), Charlotte Morris (CMo), James R. Morris, Oscar T. Moss, Dominik Mosur (DMo), Brennan Mulrooney (BMu), Steve Myers, Joey Negreann, Dan W. Nelson (DnN), David W. Nelson (DvN), Kristie N. Nelson, Aernout Nieuwkerk, Gary Nunn, Brittany O'Connor (ByO), Brook O'Connor (BkO), Suzanne O'Rourke, Fabio Olmos, Kurt Ongman, Nancy J. Overholtz, Ron Overholtz, Ed Pandolfino, Laura Paulson (LPa), David Pereksta (DPe), John Perry (JPe), James E. Pike, Norman Pillsbury, Dan Pittenger (DPi), Linda Pittman (LPi), David Povey (DPo), Jeremiah Psiropoulos (JPs), David E. Quady, David T. Rankin, Hugh P. Ranson, Mark J. Rauzon, Robert W. Reiling, Casey Richart (CRi), Bruce Rideout, Alex M. Rinkert, Don Roberson, Geoffrey L. Rogers, Jack Rogers, Carole Rose (CRo), Kerry G. Ross, Stephen C. Rottenborn, Martin Ruane, Ruth A. Rudesill, Tuck Russell, Casey N. Ryan, Matt Sadowski (MSad), Edana Salisbury, Isaac Sanchez, John Sanders (JoS), Larry Sansone (LSa), Paul Saraceni, Naresh Satyan, Mark Sawyer (MSaw), Jim Scarff (JiS), Dean Schaff (DSch), Mark A. Scheel, Roger Schoedl, Jean Scholes (JSch), Christian Schoneman (CScho), Brad K. Schram, Mark Schulist (MSc), Chuck Schussman (CSchu), Christian Schwarz (CSchw), Conor Scotland (CoS), Julie Scotland (JuS), Dan Scott (DSco), Adam J. Searcy, Mel Senac (MSe), Debra L. Shearwater, Alison M. Sheehey, Desmond Sieburth (DSi), Daniel S. Singer, Keith M. Slauson, James P. Smith, Susan E. Smith, David Sonneborn (DSo), Jeffrey Spaulding (JeS), Kate Spencer (KSp), Chris Spurgeon (CSp), Lea Squires (LSq), Mark E. Stacy, Justyn T. Stahl, John R. Stanek, Cuyler Staplemann (CuS), Bob Steele, Susan L. Steele, Mike Stensvold (MiS), Mark Stephenson (MSte), Don Sterba (DSt), John C. Sterling, Mike Stiles (MSti), Caleb Strand (CaS), Mark Stratton (MStr), Steve Stump (SSt), Karen Suarez (KSu), Brian L. Sullivan, Steven Summers (SSu), Linda Swanson (LSw), Kirk Swenson (KSw), David Syzdek (DSy), Christopher Taylor (CTa), Monte M. Taylor, Glen Tepke (GTe), Linda S. Terrill, Scott B. Terrill, Paula Theobald, Cindy Thill (CTh), Holly Thomas, Ronald S. Thorn, James R. Tietz, Jerry Ting, Guy Tingos (GTi), Jennifer M. Tobin, Richard J. Todoroff, Bob Toleno (BTo), Gerald L. Tolman, Delaney Trowbridge, Steve Tucker, Manolo Turner (MTu), Thomas Turner, Breck Tyler (BTy), Mark Tyson (MTy), Philip Unitt, Roger Uzun, Wim van Dam, David Vander Pluym, Samuel Vassalo, Willem Visser, Robin Wachs (RoW), Shawn Wagoner (ShW), Kathleen Waldron, Stan Walens (StW), Rudyard Wallen (RuW), Randy Wardle (RaW), Niles Warnock, Len Warren, Wayne Washam, Kenneth L. Weaver, Matthew West (MWe), Eric Wier, Alan N. Wight, Ryan S. Winkleman, Mark Woodruff (MWo), Brian Woolley, Thomas E. Wurster, David G. Yee, Eric A. Yee, and Chezy L. Yusuf.

\section{LITERATURE CITED}

Allen, L. W., Garrett, K. L., and Wimer, M. C. 2016. Los Angeles County Breeding Bird Atlas. Los Angeles Audubon Soc., Los Angeles.

Baicich, P. J., Heinl, S. C., and Toochin, M. 1996. First documented breeding of the Eurasian Skylark in Alaska. W. Birds 27:86-88. 
Banks, R. C., and Laybourne, R. C. 1968. The Red-whiskered Bulbul in Florida. Auk 85:141; doi.org/10.2307/4083644.

Barber, M. 1985. Bird wins reprieve in battle of the bulbul. Los Angeles Times, 29 December.

Baumann, M. J., Galen, S. C., Pederson, N. D., and Witt, C. C. 2014. Simple technique for distinguishing Yellow-bellied Flycatchers from Cordilleran and Pacific-slope flycatchers. J. Field Ornithol. 85:391-396; doi.org/10.1111/jofo.12078.

Bibles, B. D., Glinski, R. L., and Johnson, R. R. 2002. Gray Hawk (Buteo plagiatus), in The Birds of North America (A. F. Poole and F. B. Gill, eds.), no. 652. Birds N. Am., Inc., Philadelphia; doi.org/10.2173/bna.652.

Bot, S., Groenenjijk, D., and van Oosten, H. H. 2017. Eastern Yellow Wagtails in Europe: Identification and vocalisations. Dutch Birding 26:295-311.

Brazil, M. 2009. Birds of East Asia: China, Taiwan, Korea, Japan, and Russia. Princeton Univ. Press, Princeton, NJ.

Brightsmith, D., Burgio, K. R., Hiller, B. J., Block, K. E., Pyle, P., and Patten, M. A. 2017. Yellow-chevroned Parakeet (Brotogeris chiriri), in The Birds of North America (P. G. Rodewald, ed.). Cornell Lab Ornithol., Ithaca, NY; doi. org/10.2173/bna.yecpar.03.

California Bird Records Committee (R. A. Hamilton, M. A. Patten, and R. A. Erickson, eds.). 2007. Rare Birds of California. W. Field Ornithol., Camarillo, CA.

California Bird Records Committee (J. R. Tietz and G. McCaskie, eds.). 2020. Update to Rare Birds of California, 1 January 2004 - 9 April 2020; https://www. californiabirds.org/cbrc_book/update.pdf.

Chesser, R. T., Burns, K. J., Cicero, C., Dunn, J. L., Kratter, A. W., Lovette, I. J., Rasmussen, P. C., Remsen, J. V. Jr., Stotz, D. F., and Winker, K . 2019. Sixtieth supplement to the American Ornithological Society's Check-list of North American Birds. Auk 136:CSi-CSxxiii; doi.org/10.1093/auk/ukz042.

Corman, T., and Tomoff, C. 2015. Yavapai, in Arizona seasonal reports 2015. Ariz. Field Ornithol.; http://azfo.org/seasonalReports/2015_spring.html.

DeCicco, L. H., Gibson, D. D., Tobish, T. G. Jr., Heinl, S. C., Hajdukovich, N. R., Johnson, J. A., and Wright, C. W. 2017. Birds of Middleton Island, a unique landfall for migrants in the Gulf of Alaska. W. Birds 48:214-293; doi 10.21199/WB48.4.1.

Dunn, J. L., and Alderfer, J. 2017. National Geographic Field Guide to the Birds of North America, $7^{\text {th }}$ ed. Natl. Geogr. Soc., Washington, DC.

Dunn, J. L., and Garrett, K. L. 1997. A Field Guide to the Warblers of North America. Houghton Mifflin, Boston.

Erickson, R. A., and Hamilton, R. A. 2001. Report of the California Bird Records Committee: 1998 records. W. Birds 32:13-49.

Garrett, K. L. 2018. Introducing change: A current look at naturalized bird species in western North America, in Trends and traditions: Avifaunal change in western North America (W. D. Shuford, R. E. Gill Jr., and C. M. Handel, eds.), pp. 116-130. Studies of Western Birds 3. W. Field Ornithol., Camarillo, CA; doi. org/10.21199/SWB3.5.

Gibson, D. D., and Withrow, J. J. 2015. Inventory of the species and subspecies of Alaska birds, second edition. W. Birds 46:94-185.

Hamilton, R. 2008. Fulvous Whistling-Duck (Dendrocygna bicolor), in California Bird Species of Special Concern: A ranked assessment of species, subspecies, and distinct populations of birds of immediate conservation concern in California (W. D. Shuford and T. Gardali, eds.), pp. 68-73. Studies of Western Birds 1. W. Field Ornithol., Camarillo, CA, and Calif. Dept. Fish and Game, Sacramento.

Harvey, C., Garfield, N., Williams, G., Tolimieri, N., Schroeder, I., et 51 al. 2019. Ecosystem status report of the California Current for 2019: A summary of ecosystem indicators compiled by the California Current Integrated Ecosystem 
Assessment Team (CCEIA). NOAA Tech. Memorandum NMFS-NWFSC-149; doi.org/10.25923/p0ed-ke21.

Heindel, M. T., and Garrett, K. L. 1995. Sixteenth annual report of the California Bird Records Committee. W. Birds 26:1-33.

Heindel, M. T., and Garrett, K. L. 2008. The $32^{\text {nd }}$ report of the California Bird Records Committee: 2006 records. W. Birds 39:121-152.

Hitchcock, J. C. 1987. Status of the Red-whiskered Bulbul Pycnonotus jocosus in the Los Angeles area: Report of surveys at the Huntington May 5, 1987, and Los Angeles State and County Arboretum May 6, 1987. Special Report, Calif. Dept. Food and Agriculture.

Howell, S. N. G. 2012. Petrels, Albatrosses, and Storm-Petrels of North America: A Photographic Guide. Princeton Univ. Press, Princeton, NJ; doi. org/10.1515/9781400839629.

Howell, S. N. G., and Pyle, P. 2015. Use of "definitive" and other terms in molt nomenclature: A response to Wolfe et al. (2014). Auk 132:365-369; doi.org/10.1642/ AUK-14-180.1.

Howell, S. N. G., and Zufelt, K. 2019. Oceanic Birds of the World: A Photo Guide. Princeton Univ. Press, Princeton, NJ; doi.org/10.2307/j.ctvg254dg.

Howell, S. N. G., Corben, C., Pyle, P., and Rogers, D. I. 2003. The first basic problem: A review of molt and plumage homologies. Condor 105:635-653; doi. org/10.1093/condor/105.4.635.

Howell, S. N. G., Lewington, I., and Russell, W. 2014. Rare Birds of North America. Princeton Univ Press, Princeton, NJ; doi.org/10.1515/9781400848072.

Humphrey, P. S., and Parkes, K. C. 1959. An approach to the study of molts and plumages. Auk 76:1-31; doi.org/10.2307/4081839.

Iliff, M. J., McCaskie, G., and Heindel, M. T. 2007. The $31^{\text {st }}$ report of the California Bird Records Committee: 2005 records. W. Birds 38:161-205.

Iliff, M. J., Erickson, R. A., and Billings, M. J. 2008. Reassessment of Tropical Parula subspecies in Baja California Sur. W. Birds 39:69-81.

Kahle, L. 2019. First record of the Eastern Meadowlark for California. W. Birds 50:196-199; doi.org/10.21199/WB50.3.10.

Leatherman, D., and Mammoser, J. 2007. Colorado's first record of Tropical Parula. Colo. Birds 41:164-174.

Lockwood, M. W., and Freeman, B. 2004. The TOS Handbook of Texas Birds, 2nd ed. Tex. A\&M Univ. Press, College Station.

Luther, J. S. 1980. Fourth report of the California Bird Records Committee. W. Birds 11:161-173.

McCaskie, G., and San Miguel, M. 1999. Report of the California Bird Records Committee: 1996 records. W. Birds 30:57-85.

McCaskie, G., Rottenborn, S. C., Terrill, S. B., and Benson, T. A. 2018. The $42^{\text {nd }}$ annual report of the California Bird Record Committee: 2016 records. W. Birds 49:238-257; doi.org/10.21199/WB49.4.1.

Millsap, B. A., Seipke, S. H., and Clark, W. S. 2011. The Gray Hawk (Buteo nitidus) is two species. Condor 113:326-339; doi.org/10.1525/cond.2011.100089.

Monson, G., and Phillips, A. R. 1981. Annotated Checklist of the Birds of Arizona. Univ. of Ariz. Press, Tucson.

Morlan, J., and Erickson, R. A. 1983. A Eurasian Skylark at Point Reyes, California, with notes on skylark identification and systematics. W. Birds 14:113-126.

Nelson, K. N., Rottenborn, S. C., and Terrill, S. B. 2013. The $37^{\text {th }}$ report of the California Bird Records Committee: 2011 records. W. Birds 44:206-236.

Oswald, J. A., Harvey, M. G., Remsen, R. C., Foxworth, D. U., Dittmann, D. L., Cardiff, S. W., and Brumfield, R. T. 2019. Evolutionary dynamics of hybridization and introgression following the recent colonization of Glossy Ibis (Aves: Plegadis 
falcinellus) into the New World. Molec. Ecol. 28:1675-1691; doi.org/10.1111/ mec.15008.

Patten, M. A., and Erickson, R. A. 1994. Fifteenth report of the California Bird Records Committee. W. Birds 25:1-34.

Patten, M. A., Finnegan, S. E., and Lehman, P. E. 1995. Seventeenth report of the California Bird Records Committee: 1991 records. W. Birds 26:113-143.

Phillips, A., Marshall, J., and Monson, G. 1964. The Birds of Arizona. Univ. of Ariz. Press, Tucson.

Pike, J. E., and Compton, D. M. 2010. The $34^{\text {th }}$ report of the California Bird Records Committee: 2008 records. W. Birds 41:130-159.

Pike, J. E., Garrett, K. L., and Searcy, A. J. 2014. The $38^{\text {th }}$ report of the California Bird Records Committee: 2012 records. W. Birds 45:246-275.

Pyle, P., Gustafson, M., Johnson, T., Kratter, A. W., Lang, A., Nelson, K., Lockwood, M. W., and Sibley, D. 2019. 30th report of the ABA Checklist Committee, 2019. Birding 51:36-43.

Pyle, R. L., and Pyle, P. 2017. The Birds of the Hawaiian Islands: Occurrence, History, Distribution, and Status, version 2. B. P. Bishop Mus., Honolulu; http:// hbs.bishopmuseum.org/birds/rlp-monograph/.

Regelski, D. J., and Moldenhauer, R. R. 2012. Tropical Parula (Setophaga pitiayumi), in The Birds of North America (A. F. Poole, ed.), no. 293, version 2.0. Cornell Lab Ornithol., Ithaca, NY; doi.org/10.2173/bna.293.

Rosenberg, G. H., Radamaker, K., and Vander Pluym, D. 2017. Arizona Bird Committee report, 2010-2014 records. W. Birds 48:74-112; doi.org/10.21199/ WB48.2.1.

Rosenberg, K. V., Ohmart, R. D., Hunter, W. C., and Anderson, B. W. 1991. Birds of the Lower Colorado River Valley. Univ. of Ariz. Press, Tucson.

Rottenborn, S. C., McCaskie, G., Daniels, B. E., and Garrett, J. 2016. The 39th annual report of the California Bird Records Committee: 2013 records. W. Birds 47:2-26.

Searcy, A. J., Daniels, B. E., Feenstra, J. S., Tietz, J. R., and Benson, T. A. 2018. The $41^{\text {st }}$ annual report of the California Bird Records Committee: 2015 records. W. Birds 49:24-46; doi.org/10.21199/WB49.1.2.

Singer, D. S., and Terrill, S. B. 2009. The $33^{\text {rd }}$ report of the California Bird Records Committee: 2007 records. W. Birds 40:158-190.

Singer, D. S., Dunn. J. L., Harter, L. B., and McCaskie, G. 2016. The $40^{\text {th }}$ annual report of the California Bird Records Committee: 2014 records. W. Birds 47:291-313; doi.org/10.21199/WB47.4.3.

Singer, D. S., Benson, T. A, McCaskie, G., and Stahl, J. 2020. The $43^{\text {rd }}$ annual report of the California Bird Records Committee: 2017 records. W. Birds 51:2-26; doi. org/10.21199/WB51.1.1.

Tompkins, E. M., Townsend, H. M., and Anderson, D. J. 2017. Decadal-scale variation in diet forecasts persistently poor breeding under ocean warming in a tropical seabird. PLoS One 12(8): e0182545; doi.org/10.1371/journal.pone.0182545.

Warzybok, P., Bradley, R., and Howell, S. N. G. 2009. First North American record of Tristram's Storm-Petrel (Oceanodroma tristrami). N. Am. Birds 62:634-636.

Witzeman, J., and Corman, T. 2017. Birds of Phoenix and Maricopa County, Arizona. Maricopa Audubon Soc., Phoenix. 


\section{BOOK REVIEW}

An Expedition to Ramsey Canyon: The 1896 Field Journal of Ornithologist Harry S. Swarth, by Christopher W. Swarth, 2018. Yaqui Gulch Press, 88 pp. Many drawings, maps, photos, and tables. Paperback, \$ 15.99. ISBN 978-1724410382.

Christopher Swarth's publication of his ornithologist grandfather's journal of his first trip to Arizona, then called the Arizona Territory, transports the reader back to the 1800s and to a time when birding and field ornithology were much different from today. This era was a time of great ornithological discovery and when little was known about Arizona's unique avifauna. This slender volume of Harry S. Swarth's journal is not only a readable scientific document of a bygone era, it remains a relevant description for comparison to the avifauna of Ramsey Canyon in the $21^{\text {st }}$ century. The book is organized into three sections.

Part One of An Expedition to Ramsey Canyon begins with the 18-year-old Harry Swarth's expedition field journal, with notes and descriptions, in verbatim, of his 650mile journey with three other young men, Ozzie Howard, Will Judson, and Harry Rising. The journey starts in Los Angeles on 29 February 1896. After eight weeks on the trail, the young men arrive in Ramsey Canyon, where they remain until 17 July. Harry's field notes, pages $2-57$, may seem a bit repetitious, but his descriptions of the day-to-day hardships, habitat, and activities are captivating.

The difficulty and hardship of traveling for months via covered wagon, living off the land, and caring for the horses while remaining steadfast to writing field notes, collecting birds, and preparing specimens cannot be overstated. It is hard for today's reader to overlook the fact that we live in an era that delays our young people from stepping off the edge into adulthood and independence. In young Harry's era, the wherewithal and maturity needed to accomplish such a trip were still formidable but not insurmountable, and his experience sets an example for today's aspiring young ornithologists.

The team's journey through San Bernardino, the San Gorgonio Pass, Beaumont, and the Colorado Desert in California, before the Salton Sea, brought back a lot of memories. I grew up birding this "Inland Empire" of California. In 1896 most of the area between Los Angeles and the Territory of Arizona was sparsely inhabited or wilderness, and California Condors still soared the skies. The Inland Empire is now a network of freeways, industry, and urban/suburban sprawl. And, counting even for traffic, in the $21^{\text {st }}$ century Harry's trek can be made in a day of air-conditioned driving. The gradual but profound changes in the landscape, fauna, and avifauna between the Los Angeles Basin of California and Ramsey Canyon in Arizona, which Harry appreciated at his plodding pace, are lost on nearly all of today's expeditioners making the same journey. On 17 March 1896, Swarth's group crossed the Colorado River via ferry boat into Yuma, Arizona, continued to Phoenix on 2 April, Tucson on 4 April, and finally reached Ramsey Canyon after nearly two months of travel on 24 April.

Young Harry's descriptions of the habitat and birds of Ramsey Canyon reveal conditions very similar to today's. The canyon remains a pilgrimage point for ornithologists and birders from all over the globe. The Ramsey Canyon Preserve, managed by The Nature Conservancy, was first set aside in 1970 with 280 acres spared from development, and subsequent acquisitions have expanded the preserve to 380 acres.

Part Two: The second section of this slim volume, Names, Collections and Breeding Birds, pages 55-65, is a set of five tables. Table 1 contains the names of birds Harry used in his field notes and their current common and scientific names. Table 2 has the updated names of specimens from the expedition, the number in museum collections, and the museum. The other three tables detail the days and number of species encountered in the field, clutches collected, and breeding species observed. 


\section{BOOK REVIEW}

Breeding Species Observed, Table 5, also compares observations of what was seen in 1896 to species expected or likely absent today. Chris Swarth could have eliminated the table of old names vs. new names and made it more convenient for the reader by including the new name in parentheses following the old name in the field notes, but he explains that he didn't want to alter the original field notes.

Part Three, Noteworthy Birds of Ramsey Canyon, contains my favorite part of the book, the enigmatic story of the first record of the Bumblebee Hummingbird in the United States and a discussion of same. It is followed by a detailed treatment of the "nettlesome" Nutting's Flycatcher, and another on those "wonderful" red warblers of the canyon.

An Expedition to Ramsey Canyon is a pleasant and delightful read for all who wandered off young and explored, for those who followed in the $20^{\text {th }}$ century, and for those who will pioneer the $21^{\text {st }}$ century. In a book just 88 pages, in an afternoon the reader can be carried back in time to the age of discovery and birding in a world without cars, social media, or Internet.

Kurt A. Radamaker

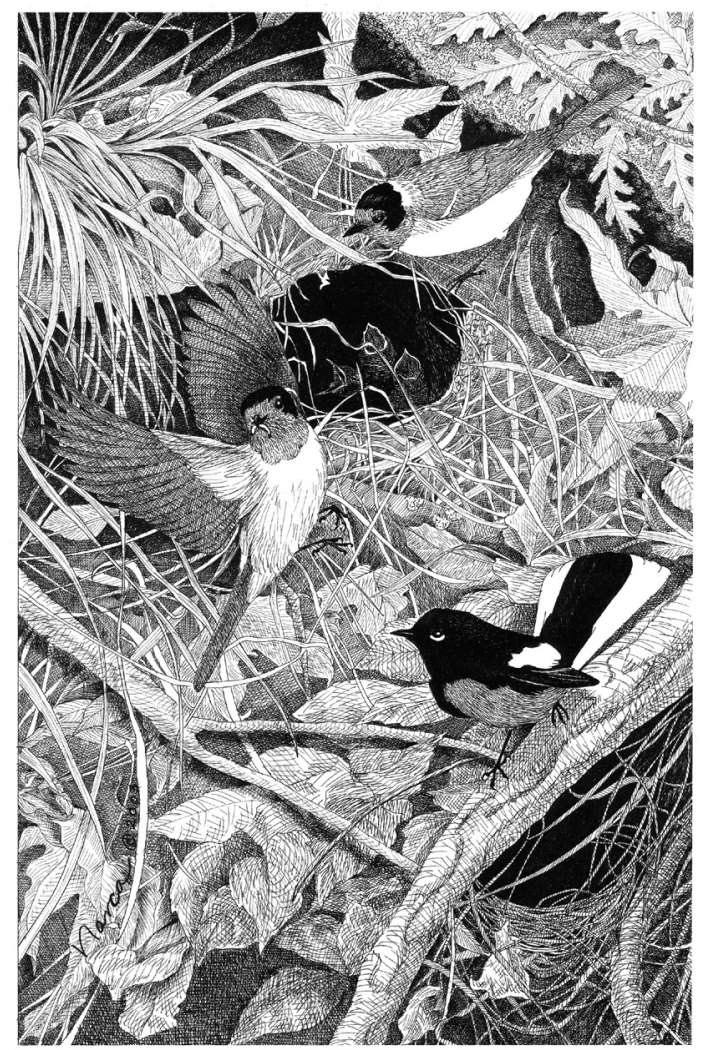

Red-faced Warbler and Painted Redstart

Drawing by Narca Moore-Craig 


\section{FEATURED PHOTO}

\section{PUTATIVE CANYON TOWHEE $\times$ SPOTTED TOWHEE: A NEW INTERGENERIC HYBRID}

DAVID TØNNESSEN, 5230 Sevenoaks Drive, Colorado Springs, Colorado 80919; davidtonnessenx@gmail.com

At an elevation of $1800 \mathrm{~m}$ on the outskirts of Colorado Springs, Colorado, among iron-rich hillsides laden with mixed piñon-juniper woodland and Gambel's oak thickets where Spotted Towhees (Pipilo maculatus) breed densely, a small population of the Canyon Towhee (Melozone fusca) also resides. Along with scattered pockets of the species elsewhere in El Paso County, this population in Red Rock Canyon Open Space represents the northernmost site for the Canyon Towhee. The Canyon Towhee has been increasing in numbers and spreading slowly northward from its historic range in southeastern Colorado (B. Maynard pers. comm). In the fall of 2019, I documented an occurrence that might be characteristic of such edges of species' ranges.

On 21 and 22 November 2019 I photographed an interesting towhee in good light and from many angles (Figures 1-3). Colored overall like the Canyon Towhees it was feeding with, this individual stood out because of its smaller size, timid behavior, and odd dark smudges throughout the plumage. From its external features and behavior, I concluded that this bird was a Canyon Towhee $\times$ Spotted Towhee (Melozone fusca $\times$ Pipilo maculatus) and so the first known hybrid between the genera Melozone and Pipilo.

This individual resembled a Canyon Towhee in its rufous crown and overall tannish coloration, but several plumage oddities ruled out a pure individual of that species. A charred tinge characterized the upperparts, where the mantle showed a slightly streaked pattern, while the flanks were slightly brighter and buffy. The face and breast had blackish areas lacking in a Canyon Towhee, while slight pale markings in the lores and throat broke these dark tones. On the underparts, tan tones in the breast gave way to a white belly and the contrasting rufous of the undertail coverts. All this suggested a hybrid, and a potential identification challenge.

The $50 \%$ of their genome that offspring receive from each parent represents a random combination of each parent's genes. This means phenotypes of the same hybrid combination can be extremely variable, one reason why hybrids are notoriously often challenging to identify.

To eliminate a Green-tailed Towhee $\times$ Spotted Towhee $(P$. chlorurus $\times$ P. maculatus), a hybrid known to exhibit a phenotype not dissimilar from this individual, I noted several key marks. Overall, the bird had a tannish plumage reminiscent of a Canyon Towhee, with a tan that wrapped farther onto the venter than in either a pure Green-tailed or a pure Spotted Towhee. The buffy tinge in the lores, malar area, and throat resembled markings of a Canyon Towhee, where a hybrid with a Green-tailed Towhee as a parent would be expected to show white markings. The breast had a mottled buffy pattern similar to Canyon Towhee's, but darker, possibly as a result of Spotted Towhee influence. One would expect a grayer color in this area if one of the parents was a Green-tailed Towhee (see Figure 4).

Perhaps the most apparent feature of Canyon Towhee parentage was seen in the color of the undertail coverts. In the Spotted Towhee, the tawny undertail coverts are paler than the rufous sides, and in the Green-tailed Towhee the pale buff undertail coverts are paler than the grayish flanks. In this bird, the vent was contrastingly deeper rufous than the rest of the underparts, implying that a Canyon Towhee was one of the parents (see Figures 2 and 3 ). 


\section{FEATURED PHOTO}

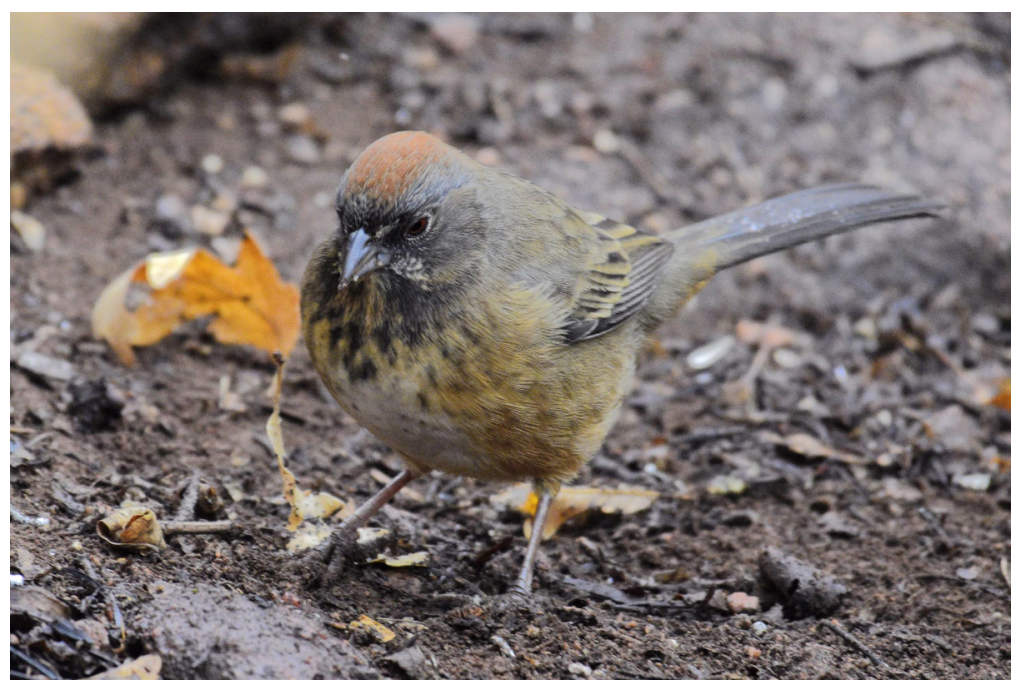

Figure 1. Canyon $\times$ Spotted Towhee, 21 November 2019, Colorado Springs, Colorado. A mottled buffy pattern is visible in the breast, where any Green-tailed Towhee influence would not be expected to produce such a color.

Photo by David Tønnessen

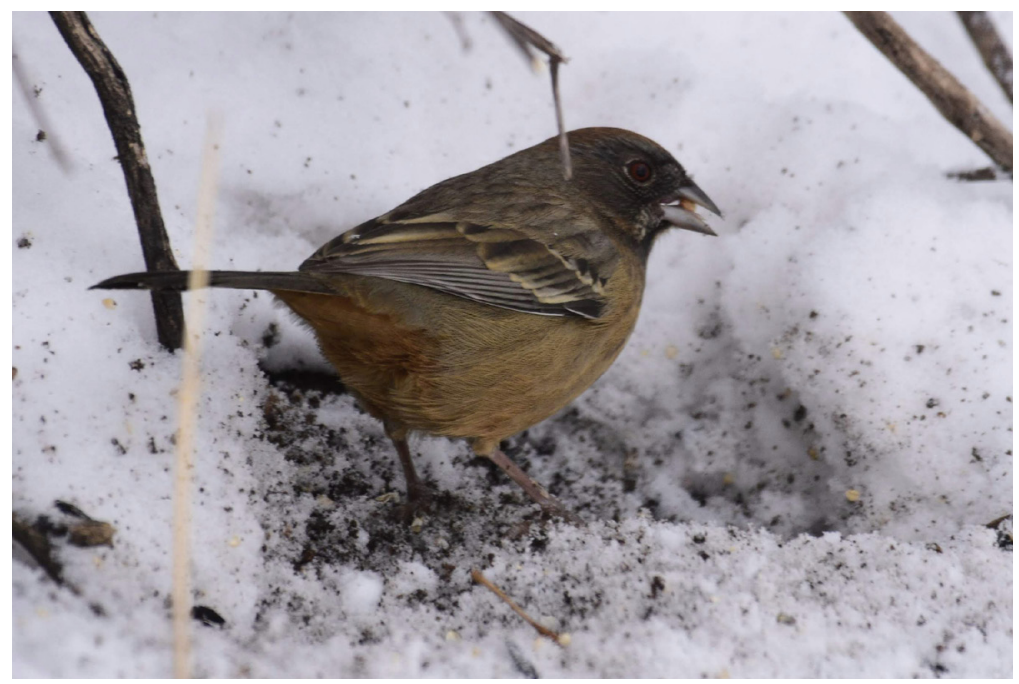

Figure 2. Canyon $\times$ Spotted Towhee, 22 November 2019, Colorado Springs, Colorado. The contrasting rufous undertail coverts are a feature of the Canyon Towhee, but not the Green-tailed. 


\section{FEATURED PHOTO}

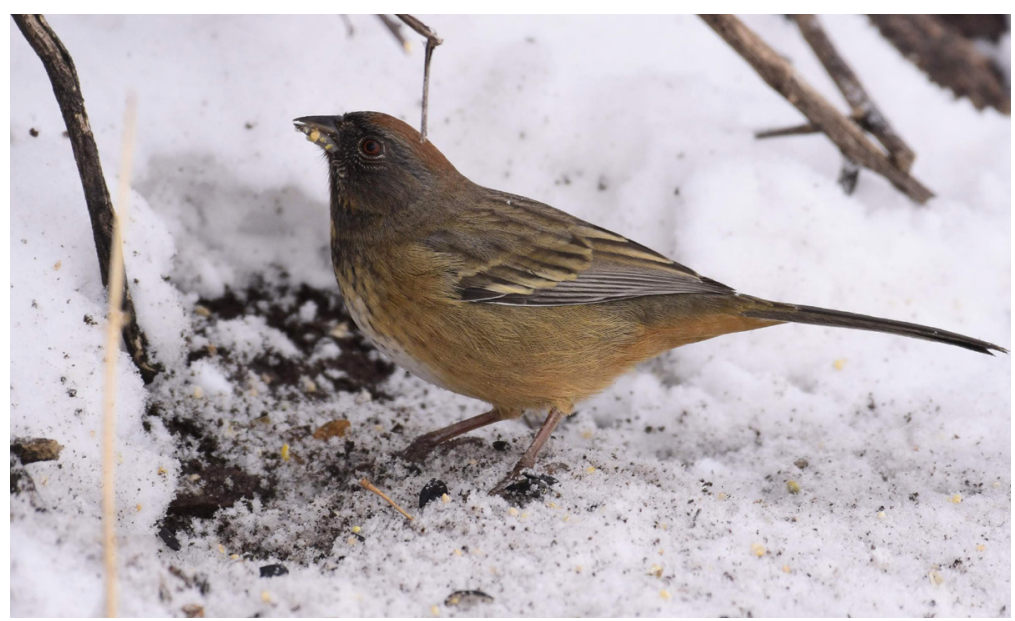

Figure 3. Lateral view of Canyon $\times$ Spotted Towhee, 22 November 2019, Colorado Springs, Colorado.

Photo by David Tønnessen
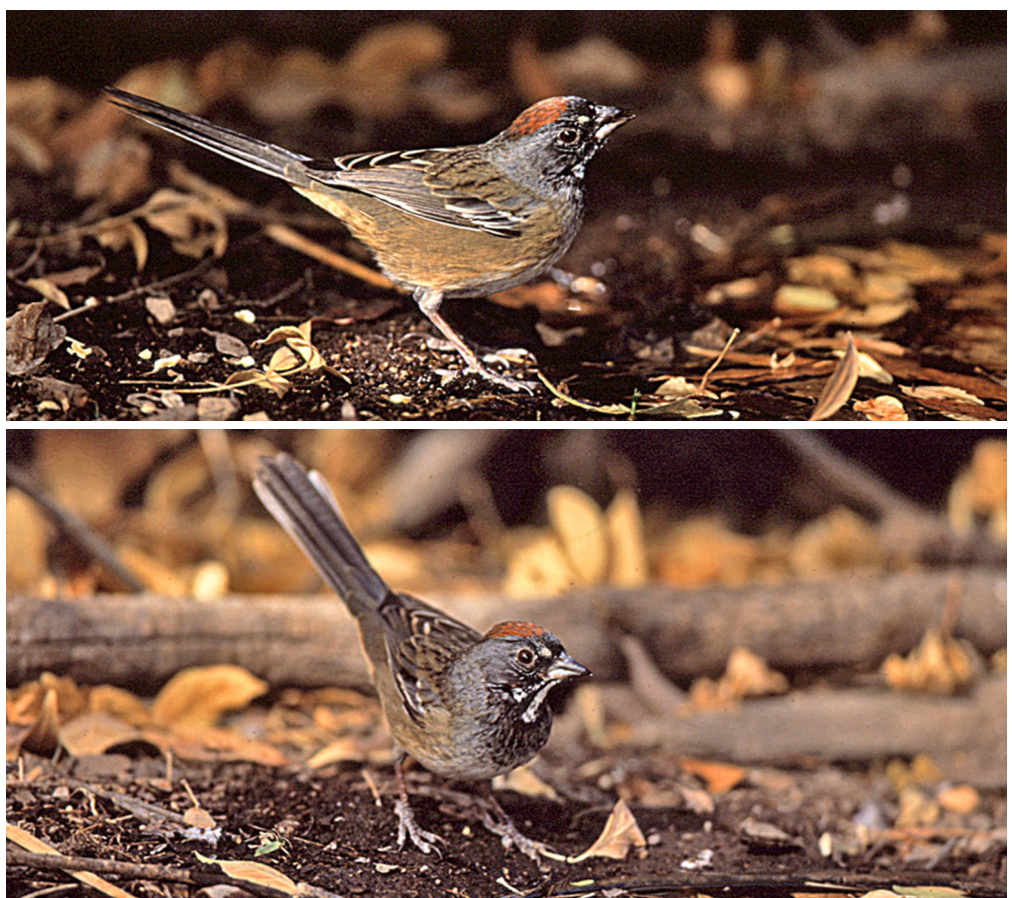

Figure 4. Green-tailed $\times$ Spotted Towhee, 26 November 2005, Ash Canyon, Arizona.

Photos by Jim Burns 


\section{FEATURED PHOTO}

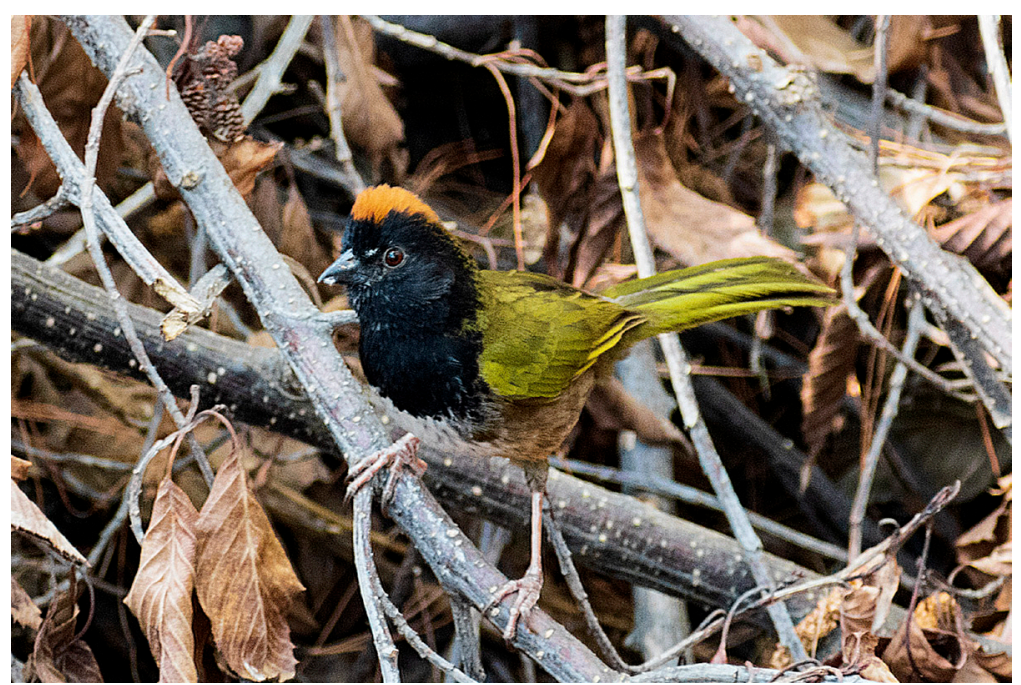

Figure 5. Spotted $\times$ Collared Towhee, 9 April 2019, Cerro Patambán, Michoacán, Mexico.

Photo by Ricardo Arredondo

A third hybrid combination that may be considered is a Canyon $\times$ Green-tailed Towhee, because of extensive gray in the plumage and lack of observable spots at the tips of the rectrices that might be expected if one of the parents was a Spotted Towhee. However, the blackish coloration in the face and whitish belly strongly support a Spotted Towhee as one parent. Furthermore, the only Green-tailed Towhees breeding in El Paso County occur $300 \mathrm{~m}$ higher in elevation, while the Spotted Towhee is the most numerous species of breeding bird in Red Rocks Canyon Open Space, making the latter far more likely.

Of possible locations within the range of the Canyon Towhee where such a hybrid might occur, Colorado Springs should be the least surprising. In Red Rock Canyon Open Space, the population of the Canyon Towhee in late 2019 numbered no more than four birds, perhaps all part of the same immediate family, making it difficult for them to find conspecific mates. The Canyon Towhee has colonized the Colorado Springs area since field work for the second Colorado breeding bird atlas, 2007-2012, though it was in southwestern El Paso County by the time of field work for the first Colorado breeding bird atlas, 1987-1995 (Colorado Bird Atlas Partnership 1998, 2016). Hybrids between distantly related species sometimes occur at range edges, where the population of one parental species has not yet reached a self-sustaining level.

Such a pattern has been well demonstrated by jays of the genus Cyanocitta. In 1969 , four Steller's $\times$ Blue Jay $($ C. stelleri $\times$ C. cristata) hybrids were documented in Boulder, Colorado (Williams and Wheat 1971). At that time the Blue Jay had only recently expanded into Colorado's Front Range, and its populations were quite small. Today, Blue Jay numbers in that area are considerably higher, making a Blue Jay's chances of finding a conspecific mate much greater. But reports to www.eBird.org reveal that this same hybrid has been showing up in parts of the Pacific Northwest and southwestern Canada in more recent years, where the Blue Jay is still in the process of establishing new populations. 
A study of hybridization between the Black-capped (Poecile atricapillus) and Mountain (P. gambeli) chickadees in British Columbia (Grava et al. 2012) suggested a similar pattern. That research found that while the Black-capped and Mountain chickadees are typically reproductively isolated-Mountain Chickadees preferring coniferous woods and Black-capped Chickadees preferring deciduous trees-they interact in disturbed areas where deciduous regrowth following logging allows Black-capped Chickadees to establish themselves. This might be a result of the early successional stage of such environments, including cultivated plantings of coniferous trees in lowlands and plantings of deciduous trees in conifer-dominated areas resulting in one or both species colonizing in only small numbers, then hybridizing before the newly arrived species is well established.

Canyon Towhee populations in Colorado Springs are small and disjunct from one another and represent the northern fringe of the species' range. This weak presence seems to provide appropriate conditions for hybridization, paralleling the pattern in the jays and chickadees. However, more study is likely needed to recognize this as a phenomenon.

While the Canyon Towhee and Spotted Towhee have not been known to hybridize with each other before, each species has been documented hybridizing with other congeneric species of towhee. In Arizona, hybrids between the Canyon Towhee and Abert's Towhee (Melozone aberti) have been photographed on several occasions (www.eBird.org). Most of these instances were in low foothills, where both species are numerous. In the genus Pipilo, the Spotted Towhee has been reported to hybridize with the Green-tailed Towhee and Collared Towhee (P. ocai) (Sibley and Sibley 1964), both species plumaged very differently from the Spotted Towhee. See Figures 4 showing a Green-tailed $\times$ Spotted Towhee, and Figure 5 illustrating a Spotted $\times$ Collared Towhee.

This particular Canyon $\times$ Spotted Towhee inhabiting Red Rock Canyon Open Space represents the first recorded hybridization between the genera Melozone and Pipilo, despite vast areas of the Southwest where the two come in contact. The occurrence at this site on the fringe of the range of the Canyon Towhee is significant to our understanding of hybridization between distantly related species and exemplifies an intriguing phenomenon.

I thank Jim Merritt for graciously hosting me in his Manitou Springs yard where I was able to document this intriguing hybrid. I also thank Scott Taylor, Steven Mlodinow, and Nathan Pieplow for advice on article structure, wording, and citations, and Kimball L. Garrett, Douglas W. Faulkner, Tony Leukering, and Jon L. Dunn for their additional reviews.

\section{LITERATURE CITED}

Colorado Bird Atlas Partnership. 1998. Colorado Breeding Bird Atlas (H. Kingery, ed.). Colo. Bird Atlas Partnership and Colo. Div. Wildlife, Denver.

Colorado Bird Atlas Partnership. 2016. The Second Colorado Breeding Bird Atlas online database. Colorado Bird Atlas Partnership, Denver; https://www.cobreedingbirdatlasii.org/.

Grava, A., Grava, T., Didier, R., Lait, L. A., Dosso, J., Koran, E., Burg, T. M., and Otter, K. A. 2012. Interspecific dominance relationships and hybridization between Black-capped and Mountain chickadees. Behav. Ecol. 23:566-572; doi. org/10.1093/beheco/arr229.

Sibley, C. G., and Sibley, F. C. 1964. Hybridization in the Red-eyed Towhees of Mexico: The populations of the southeastern plateau region. Auk 81:479-504; doi.org/10.2307/4082732.

Williams, O., and Wheat, P. 1971. Hybrid jays in Colorado. Wilson Bull. 83:343-346.

Accepted 12 May 2020 


\section{WESTERN BIRDS}

\section{Quarterly Journal of Western Field Ornithologists}

www.westernfieldornithologists.org

President: Kurt M. Leuschner, 70065 Sonora Rd. \#267, Mountain Center, CA 92561; kleuschner@collegeofthedesert.edu

Vice-President: Jon L. Dunn, 24 Idaho St., Bishop, CA 93514; cerwa@earthlink.net

Past-President: Thomas A. Blackman, 4470 Orchard Ave., San Diego, CA 92107; obeach@cox.net

Treasurer/Membership Secretary: Suzanne M. Carota, 3476 Armourdale Ave., Long Beach, CA 90808; smcarota@gmail.com

Recording Secretary: Liga Auzins Wurster, 12842 Safford East, Garden Grove, CA 92840; llauzins@yahoo.com

Directors: Kenneth P. Able, Matthew J. Baumann, Wendy Beers, Kimball L. Garrett, Homer Hansen, John H. Harris, Karen Anderson Havlena, Edward R. Pandolfino, Bryce W. Robinson, Diane Rose, Steve Rottenborn, Christopher W. Swarth

Editor: Philip Unitt, San Diego Natural History Museum, P. O. Box 121390, San Diego, CA 92112-1390; birds@sdnhm.org

Assistant Editor: Daniel D. Gibson, P. O. Box 155, Ester, AK 99725; avesalaska@gmail.com

Associate Editors: Kenneth P. Able, Matthew J. Baumann, Daniel S. Cooper, Douglas W. Faulkner, Kimball L. Garrett, Daniel D. Gibson, Robert E. Gill, Daniel R. Ruthrauff, Christopher W. Swarth

Graphics Manager: Virginia P. Johnson, 4637 Del Mar Ave., San Diego, CA 92107; gingerj5@juno.com

Photo Editor: Peter LaTourrette, 1019 Loma Prieta Ct., Los Altos, CA 94024; platourrette@ comcast.net

Featured Photo: Ryan Terrill, Moore Laboratory of Zoology, Biology Department, Occidental College, 1600 Campus Rd., Los Angeles, CA 90041

Book Reviews: Catherine Waters, P.O. Box 3505; 25131 Alicia Dr., Dana Point, CA 92629, cpannellwaters@gmail.com

WFO Website: Timothy W. Brittain; webmaster@westernfieldornithologists.org

Membership dues, for individuals and institutions, including subscription to Western Birds: Life, \$800 (payable in two equal annual installments); Family $\$ 45$; Regular U.S. $\$ 40$ for one year, $\$ 70$ for two years, $\$ 100$ for three years. Dues and contributions are tax-deductible to the extent allowed by law.

Send membership dues, changes of address, correspondence regarding missing issues, and orders for back issues and special publications to the Treasurer. Make checks payable to Western Field Ornithologists.

Back issues of Western Birds within U.S. $\$ 40$ per volume, $\$ 10$ for single issues, including shipping and handling. Outside the U.S. \$55 per volume, \$15 for single issues, including shipping and handling.

Published 31 July 2020

ISSN 0045-3897 


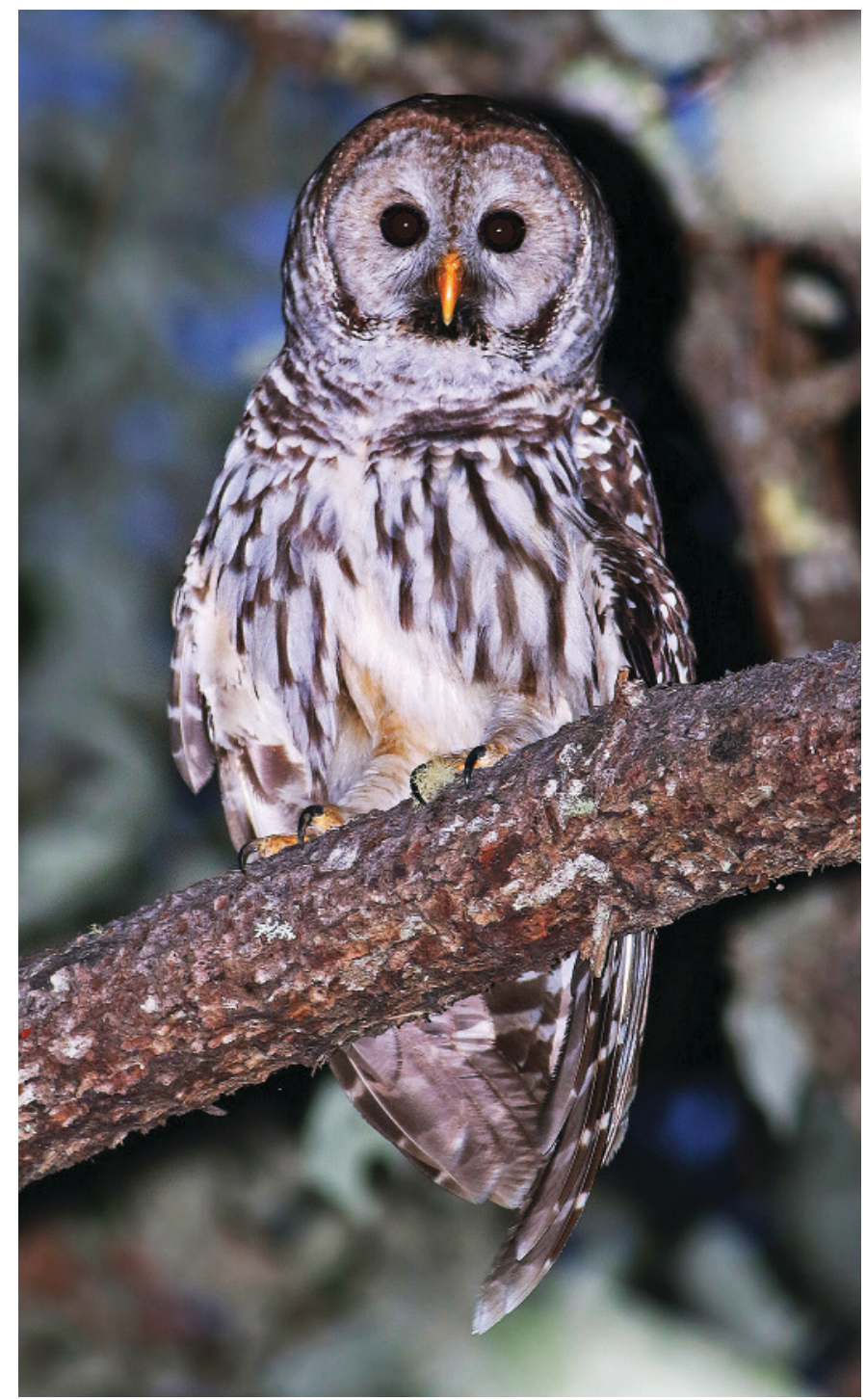

Photo by Andrew Spencer of Ithaca, New York:

Cinereous Owl (Strix sartorii), Rancho la Noria, Sierra de San Juan,

Nayarit, Mexico, 5 June 2015.

After searching six of the nine areas where the Cinereous Owl had been collected in the 19th and 20th centuries, as well as four additional sites, Nathan Pieplow, Andrew Spencer, Carlos Sanchez, and Manuel Grosselet found it at only one, as they report in this issue of Western Birds. In the 21 st century this species endemic to mainland Mexico has been reported from only two localities, implying a steep decline. Most of its habitat of pine-oak forest has been destroyed or degraded, and the Cinereous Owl may be seriously endangered. 


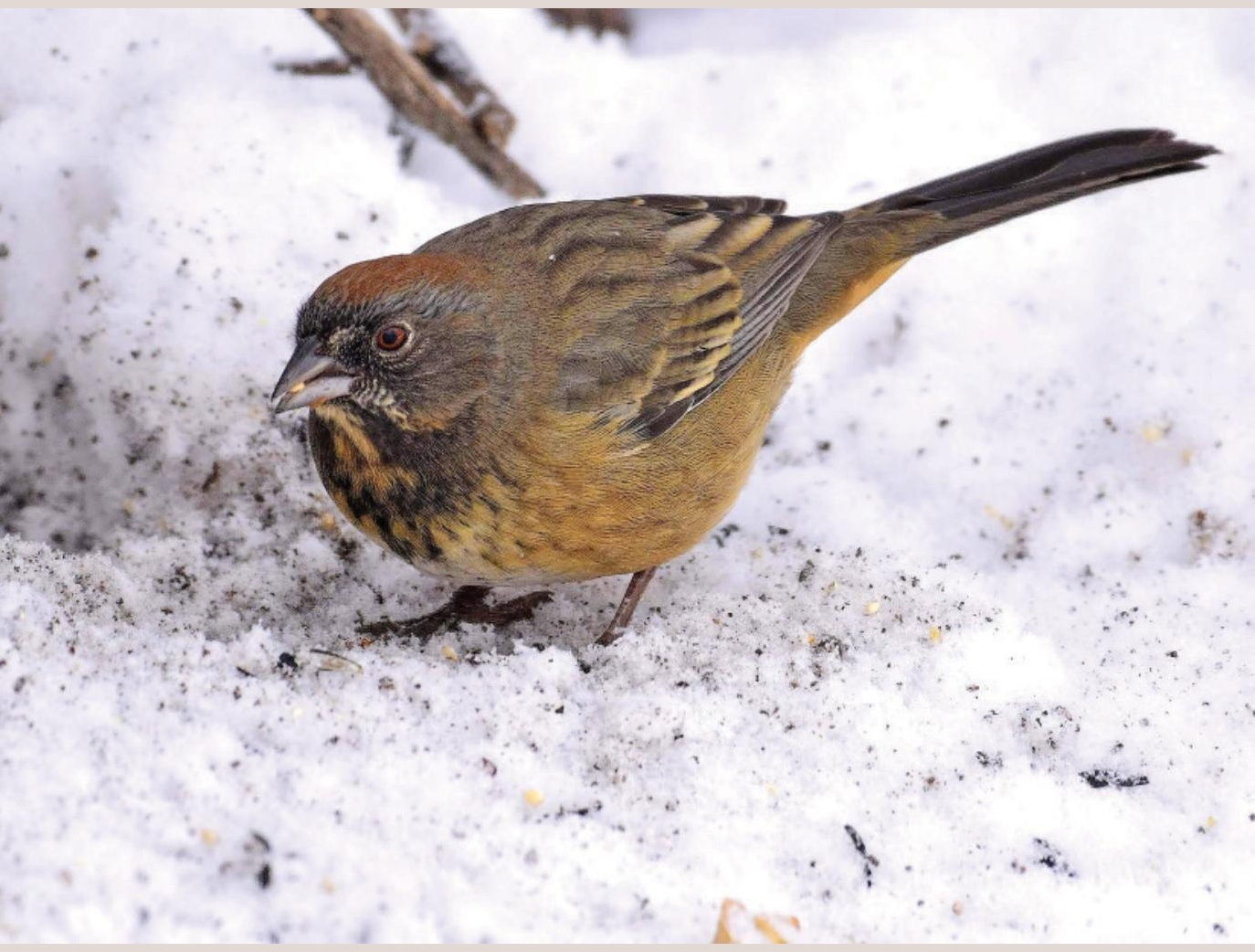

"Featured Photo" by (c) David Tønnessen of Colorado Springs, Colorado: Apparent hybrid of a Canyon Towhee (Melozone fusca) $\times$ Spotted Towhee (Pipilo maculatus), the first example of this combination.

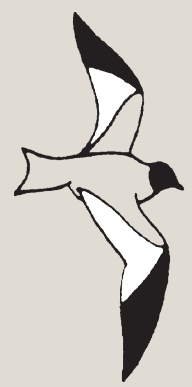

